\title{
Cretaceous faunas from Zululand and Natal, South Africa. The ammonite subfamily Mantelliceratinae Hyatt, 1903
}

\author{
William James Kennedy \\ Oxford University Museum of Natural History, Parks Road, Oxford OX1 3PW, and \\ Department of Earth Sciences, South Parks Road, Oxford OX1 3AN, U.K. \\ E-mail: jim.kennedy@oum.ox.ac.uk \\ Herbert Christian Klinger \\ Natural History Collections Department, Iziko South African Museum, P.O. Box 61, Cape Town, 8000 South Africa, and \\ 6 du Toit Street, Porterville 6810 South Africa \\ E-mail: hkling@telkomsa.net \\ \& \\ Jens Lehmann \\ Geosciences Collection, University Bremen, Faculty 5 (Geosciences), Klagenfurter Strasse, 28359 Bremen, Germany \\ E-mail: jens.lehmann@uni-bremen.de \\ (with 23 figures) \\ Received 11 February 2014. Accepted 2 June 2014
}

\begin{abstract}
The Lower Cenomanian part of the Mzinene Formation of northern KwaZulu-Natal has yielded a diverse assemblage of representatives of the cosmopolitan ammonite subfamily Mantelliceratinae Hyatt, 1903. The following species are recognized: Mantelliceras mantelli (J. Sowerby, 18I4), M. cantianum Spath, 1926a, M. picteti Hyatt, 1903, M. couloni (d’Orbigny, 1850), M. saxbii (Sharpe, 1857), M. dixoni Spath, 1926b, M. lateretuberculatum Collignon, 1964, M. nitidum (Crick, 1907), Utaturiceras vicinale (Stoliczka, 1864), Submantelliceras prenodosoides (Boule, Lemoine \& Thévenin, 1907), Sharpeiceras laticlavium (Sharpe, 1855), S. falloti (Collignon, 1931), S. mocambiquense (Choffat, 1903), S. minor sp. nov., S. florencae Spath, 1925, Sharpeiceras sp. A, and Sharpeiceras sp. B. Submantelliceras Spath, 1923, variously regarded as a synonym of Mantelliceras and other genera by previous authors, is shown to be a valid genus, and a paedomorphic dwarf.
\end{abstract}

Keywords: Cretaceous, ammonite, Cenomanian, Mantelliceratinae, KwaZulu-Natal, South Africa.

\section{CONTENTS}

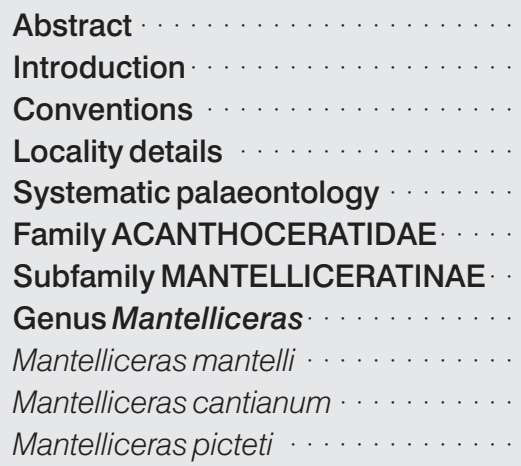

\section{INTRODUCTION}

The ammonite subfamily Mantelliceratinae are a cosmopolitan group of predominantly Early Cenomanian distribution, characterized by the absence of siphonal tubercles, and the presence of both inner and outer ventrolateral tubercles. This double ventrolateral tuberculation distinguishes them from the Stoliczkaiellinae (formerly Stoliczkaiinae, see Cooper 2012), from which they arose, and is a marker for the

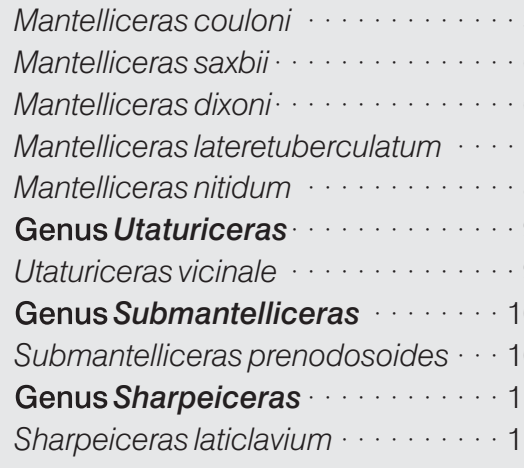

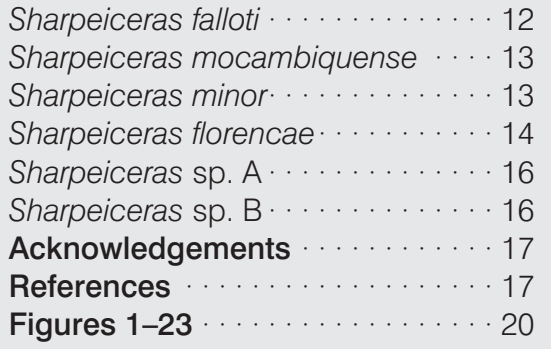

recognition of Early Cenomanian ammonite faunas. Previous records from northern KwaZulu-Natal are slight. As described below, Acanthoceras nitidum Crick, 1907 (p. 201, pl. 12, fig. 4), is a Mantelliceras, and the lectotype and one of the paratypes of Acanthoceras (Mantelliceras) falloti Collignon, 1931 (p. 81 (41) (pars), pl. 8 (4), figs 11, 12 only) is a Sharpeiceras, both species being based on material from the classic locality, the Skoenberg, northeast of Hluhluwe, 
and corresponding to localities 61 and 62 of Kennedy \& Klinger (1975). Sharpeiceras florencae Spath, 1925 (p. 198, pl. 27) was based on a large individual from what Spath termed Maputoland; we presume it to be from northeastern KwaZulu-Natal, possibly the area around Ndumu. Additional species were listed by Kennedy \& Klinger (1975). We revise these species, and describe a total of seventeen, one of which is new.

Eight of these have a relatively cosmopolitan distribution; the remainder are best known from sub-Saharan Africa and Madagascar.

\section{CONVENTIONS}

Dimensions are given in millimetres: $\mathrm{D}=$ diameter; $\mathrm{Wb}=$ whorl breadth; Wh = whorl height; $\mathrm{U}=$ umbilicus; $\mathrm{c}=$ costal dimension; ic $=$ intercostal dimension. Figures in brackets are dimensions as a percentage of the diameter. The suture terminology is that of Korn et al. (2003): $\mathrm{E}=$ external lobe; $\mathrm{A}=$ adventive lobe (= lateral lobe, $\mathrm{L}$, of Kullmann \& Wiedmann, 1970); U = umbilical lobe; I = internal lobe.

BMNH: The Natural History Museum, London.

SAM: The South African Museum, Cape Town.

OUM: Oxford University Museum of Natural History.

\section{LOCALITY DETAILS}

Details of field localities are given by Kennedy \& Klinger (1975); further descriptions of these localities are deposited in the Geological Collections, Oxford University Museum of Natural History, The Natural History Museum, London, and the Natural History Collections Department, Iziko, South African Museum, Cape Town.

\section{SYSTEMATIC PALAEONTOLOGY}

Suborder AMMONITINA Hyatt, 1889

Superfamily ACANTHOCERATOIDEA de Grossouvre, 1894

Family ACANTHOCERATIDAE De Grossouvre, 1894

Subfamily MANTELLICERATINAE Hyatt, 1903

\section{Genus Mantelliceras Hyatt, 1903}

(=Couloniceras Busnardo, 1966, p. 223; Promantelliceras Thomel, 1972, p. 31; Neomantelliceras Thomel, 1972, p. 42;

Bunburyiceras Thomel, 1972, p. 46)

\section{Type species}

By original designation: Ammonites mantelli J. Sowerby, 1814, p. 199 (ICZN Specific Name No. 1634).

\section{Diagnosis}

'Moderately involute to rather evolute; whorl section flat-sided, high and compressed to rounded and depressed. Ribs rectiradiate to prorsiradiate, straight to slightly flexed, single or branched, generally long and short, with or without umbilical, mid-lateral and inner ventrolateral tubercles, always at some stage with outer ventrolateral ones. In mature shells the umbilical seam egresses on the body chamber and the ornament is modified by further reduction of tuberculation and by strengthening of the ribs which generally become wide and evenly rounded or flattened until near the aperture.
Dimorphism consists primarily of size differentiation; the largest macroconchs are commonly about twice the diameter of the largest microconchs.

The suture has a deeply bifid rectangular external saddle, long, variably trifid to bifid first lateral lobe and normally four, commonly retracted, umbilical lobes in the mature external suture line' (Wright \& Kennedy, 1984, p. 97).

\section{Occurrence}

Lower Cenomanian, Europe, Africa, Madagascar, Asia, India, Texas, and New Mexico in the United States, Mexico, Brazil, El Salvador.

\section{Mantelliceras mantelli (J. Sowerby, 1814)}

Figs 1A-G, 2C-H, K, L, 3D-K, N, O

1814 Ammonites mantelli J. Sowerby, p. 119, pl. 55, lower figure only.

1984 Mantelliceras mantelli (J. Sowerby, 1814); Wright \& Kennedy, p. 99, pl. 16, fig. 5; pl. 17, figs 1, 3; pl. 18, figs 1-3; pl. 19, figs 1-6; pl. 20, figs 1, 2, 4; pl. 21, figs 2, 4; pl. 24, fig. 3; pl. 36, fig. 1; text-figs 20a-d, 26a, c, e, 28a-e (with full synonymy).

1998 Mantelliceras mantelli (J. Sowerby, 1814); Kaplan, Kennedy, Lehmann \& Marcinowski, p. 115, pl. 11, figs 1, 2; pl. 17, figs 12, 13; pl. 19, figs 1-9; pl. 22, figs 3, 4; pl. 23, fig. 8; pl. 24, figs 4-6; pl. 25, figs 1-5 (with additional synonymy)

1998 Mantelliceras mantelli (J. Sowerby, 1814); Lehmann, p. 20, pl. 2, fig. 4.

2002 Mantelliceras mantelli (J. Sowerby, 1814); Amédro, Cobban, Breton \& Rogron, p. 10, pl. 3, fig. 1; pl. 4, fig.1

2009 Mantelliceras mantelli (J. Sowerby, 1814); Wilmsen, Wood, Niebuhr \& Kaplan, p. 114, text-fig. 3.

2011 Mantelliceras mantelli (J. Sowerby, 1814); Mosavina \& Wilmsen, p. 178, text-fig. 3a-e (with additional synonymy).

2011 Mantelliceras mantelli (J. Sowerby, 1814); Kennedy, Amédro, Robaszynski \& Jagt, p. 221, fig. 11a-c.

?2013 Mantelliceras mantelli (?) Sowerby; Reboulet, Giraud, Colombié \& Carpentier, text-fig. 4d.

2013 Mantelliceras mantelli (J. Sowerby, 1814); Kennedy, Walaszczyk, Gale, Dembicz \& Praszkier, p. 634, pl. 2, figs 1-7; pl. 3, figs 1-5.

?2013 Mantelliceras cf. mantelli (J. Sowerby, 1814); Wilmsen, Storm, Fürsich \& Majidifard, p. 504, text-fig. 8f, g.

Type

The lectotype, by the subsequent designation of Kennedy (1971, p. 54), is BMNH 43940a from the Lower Cenomanian Chalk Marl of Ringmer, near Lewes, Sussex, the original of J. Sowerby (1814, pl. 55, lower figure only), reillustrated by Wright \& Kennedy (1984, pl. 18, fig. 3a-c).

Material

SAM-PCZ22281, 22414 and 22277, from the Lower Cenomanian part of the Mzinene Formation in the Ndumu area. OUM KX10310, from bed 3 of the Lower Cenomanian part of the Mzinene Formation at locality 181 of Kennedy \& Klinger (1975) in the Ndumu area. OUM KX10395, 10400, 10401, 10403 and 10406, from the Lower Cenomanian part of the Mzinene Formation at locality 185 of Kennedy \& 
Klinger (1975) in the Ndumu area. SAM-PCZ22278, and SAM-PCZ22276 and 22410, from the Lower Cenomanian part of the Mzinene Formation of the Skoenberg, locality 61 or 62 of Kennedy \& Klinger (1975). OUM KX4670, from the same horizon at locality 62, OUM KX14571-2, from the same horizon at locality 61 of Kennedy \& Klinger (1975) on the western 'horn' of the Skoenberg; OUM KX11976 from bed 7, and OUM KX12021 from bed 10 at the same locality.

\section{Dimensions}

\begin{tabular}{|l|c|c|c|c|c|}
\hline & D & Wb & Wh & Wb:Wh & $U$ \\
\hline SAM-PCZ22281 c & $\begin{array}{c}34.2 \\
(100)\end{array}$ & $\begin{array}{c}20.0 \\
(58.5)\end{array}$ & $\begin{array}{c}15.4 \\
(45.0)\end{array}$ & 1.3 & $\begin{array}{c}9.7 \\
(28.4)\end{array}$ \\
\hline SAM-PCZ22410 c, at & $\begin{array}{c}46.6 \\
(100)\end{array}$ & $\begin{array}{c}25.0 \\
(53.6)\end{array}$ & $\begin{array}{c}21.4 \\
(45.9)\end{array}$ & 1.17 & - \\
\hline
\end{tabular}

\section{Description}

SAM-PCZ22281 (Fig. 2C,D) is a juvenile of a spinose variant, $34.2 \mathrm{~mm}$ in diameter. Coiling is moderately evolute, the umbilicus comprising $28.4 \%$ of the diameter, with a flattened wall and broadly rounded umbilical shoulder. The intercostal whorl section is rectangular, with broadly rounded ventrolateral shoulders, and a wide, flattened venter. The costal section is depressed polygonal, with the greatest breadth at the lateral tubercle. Twelve primary ribs arise at the umbilical seam, and strengthen across the umbilical wall and shoulder, developing into strong, subspinose umbilical tubercles. These give rise to single strong, straight, prorsiradiate ribs that bear stronger subspinose lateral tubercles, strong rounded-conical inner ventrolateral tubercles and strong outer ventrolateral clavi, linked across the venter by a low, broad rib. Single intercalated ribs separate successive primaries, to give a total of 20 ribs at the ventrolateral shoulder. Some arise close to the umbilical shoulder, others low on the flank, both bearing a lateral tubercle of varying strength. Shorter intercalatories lack a lateral tubercle. Specimens including OUM KX10401, OUM KX10406 (Fig. 1C, D) and SAM-PCZ22414 (Fig. 2K, L) with whorl heights of up to $33.5 \mathrm{~mm}$ have comparably strong tuberculation with prominent subspinose lateral tubercles. SAM-PCZ22410 (Fig. 2E, F) is a worn phragmocone $56 \mathrm{~mm}$ in diameter, with 14 primary ribs at the umbilical shoulder, and a total of 24-26 ribs at the ventrolateral shoulder. Here, the ribs are coarser, and the tuberculation more subdued than in the previous specimens. SAM-PCZ22277 (Fig. 3F, G) and SAM-PCZ22280 (Fig. 3D, E) are slender variants of the same type. OUM KX10395 (Fig. $1 \mathrm{E}-\mathrm{G}$ ) is a $180^{\circ}$ sector of phragmocone with a maximum preserved diameter of $90 \mathrm{~mm}$, and a whorl breadth to height ratio of 1.14. Seven coarse primary ribs arise at the umbilical seam, and strengthen across the umbilical wall and shoulder, linking to coarse umbilical bullae. These give rise to very coarse, straight primary ribs with blunt lateral and inner ventrolateral bullae, and coarse outer ventrolateral clavi, linked across the venter by a coarse transverse rib. The primaries are separated by single coarse intercalated ribs that strengthen to match the primaries, and bear a comparable development of inner and outer ventrolateral tubercles. OUM KX10400 (Fig. 1A, B) is a fragment of body chamber, with a comparable development of ribs and tubercles at a whorl height of $38 \mathrm{~mm}$, as is OUM KX4670 (Fig. 3J, K). OUM KX11976 (Fig. 3H, I) is interpreted as a small adult body chamber, with weak umbilical bullae, very feeble, inner lateral tubercles, the inner ventrolateral tubercles lost, the outer ventrolateral clavi persisting. SAM-PCZ22276 (Fig. 2G, H) is a massive adult body chamber, on the adapical part of which all tubercles, apart from the umbilical bullae, are lost, the coarse ribs alternately long and short. The six adapertural ribs are narrower, weakening progressively, and slightly flexuous, indicating the body chamber to be that of a virtually complete adult.

\section{Discussion}

The spinose and coarsely ribbed variants described above find a match in the material from southern England described by Wright \& Kennedy (1984). SAM-PCZ22414 (Fig. 2K, L) compares well with their pl. 20, fig. 1; OUM KX10395 (Fig. 1E-G) with their pl. 18, fig. 1, the lectotype of Mantelliceras tuberculatum (Mantell, 1822), a synonym of mantelli. The polygonal whorl section with persistent umbilical, lateral, inner and outer ventrolateral tubercles distinguishes the present species from Mantelliceras cantianum Spath, 1926a (see revision in Wright \& Kennedy, 1984, p. 103, pl. 17, fig. 3; pl. 20, fig. 3; pl. 21, fig. 3; pl. 24, figs $1,2,4-6$; pl. 25, figs $1-6$; pl. 26, figs 1, 2, 4, 5; pl. 38, fig. 1; text-figs $25 \mathrm{a} ; 27 \mathrm{e}-\mathrm{h}, \mathrm{j}-\mathrm{l}$ ), where there is a weaker umbilical and stronger inner lateral tubercle, with the inner ventrolateral tubercle lost at a relatively early ontogenetic stage. In Mantelliceras picteti Hyatt, 1903 (p. 114; see revision in Wright \& Kennedy, 1984, p. 117, pl. 27, figs 1-5; pl. 28, figs 1-3; text-figs 25g; 27i, n-q), the whorl section is compressed. The primary ribs bear umbilical bullae, stronger lateral tubercles, conical inner ventrolateral tubercles and stronger outer ventrolateral clavi. The intercalated ribs bear inner and outer ventrolateral tubercles only. Mantelliceras lymense (Spath, 1926b) (pp. 427, 431; see revision in Wright \& Kennedy, 1984, p. 102, pl. 10, fig. 9; pl. 22, figs $1-6$; pl. 23 , figs $1-3$; pl. 31, figs 1 , 2; pl. 36, fig. 4; text-figs $19 ; 24 \mathrm{a}, \mathrm{b} ; 26 \mathrm{~d} ; 28 \mathrm{f}-\mathrm{j}$ ) is easily distinguished by the rounded whorl section, primary ribs with umbilical bullae and outer ventrolateral clavi, the intercalated ribs with outer ventrolateral clavi only in typical individuals.

\section{Occurrence}

Commonest in the Mantelliceras mantelli Zone of the Lower Cenomanian, but extending into the succeeding Mantelliceras dixoni Zone. The species ranges from England to Northern Ireland, France, Germany, Russia, Iran, North Africa, KwaZulu-Natal in South Africa, Madagascar, southern India, and Japan.

\section{Mantelliceras cantianum Spath, 1926a}

Fig. 2A, I, J

1926a Mantelliceras cantianum Spath, p. 82

1984 Mantelliceras cantianum Spath, 1926; Wright \& Kennedy, p. 103, pl. 17, fig. 2; pl. 20, fig. 3; pl. 21, fig. 3; pl. 24, figs 1, 2, 4-6; pl. 25, figs 1-6; pl. 26, figs 1, 2, 4, 5; pl. 38, fig. 1; text-figs 25a; 27e-h, j-I (with full synonymy). 
1998 Mantelliceras cantianum Spath, 1926a; Kaplan, Kennedy, Lehmann \& Marcinowski, p. 116, pl. 18, figs $5,6,10$, 11; pl. 20, figs 2, 3; pl. 21, figs 1-3; pl. 26, fig. 6 (with additional synonymy).

?1998 Mantelliceras cf. cantianum (Spath, 1926a); Lehmann, p. 21, pl. 3, fig. 4.

2002 Mantelliceras cantianum Spath, 1926a; Amédro, Cobban, Breton \& Rogron, p. 10, pl. 3, fig. 3; pl. 4, fig. 2.

2011 Mantelliceras cantianum Spath, 1926a; Mosavina \& Wilmsen, p. 180, text-figs 4a, b, h (with additional synonymy).

2013 Mantelliceras cantianum Spath, 1926a; Kennedy, Walaszczyk, Gale, Dembicz \& Praszkier, p. 635, textfig. $4 \mathrm{e}, \mathrm{f}$.

\section{Holotype}

By original designation, BMNH 36834, from the Lower Cenomanian Chalk Marl of Dover, Kent; paratype BMNH C5027 is from the same unit at Lewes, Sussex. They were figured by Sharpe (1857, pl. 18, figs 1, 2) and Wright \& Kennedy (1984, pl. 24, figs 2, 6).

\section{Material}

SAM-PCZ22282 and 22415, from the Lower Cenomanian part of the Mzinene Formation of the Ndumu area. OUM KX10397, from the Lower Cenomanian (Cenomanian II) part of the Mzinene Formation at locality 185 of Kennedy \& Klinger (1975) also in the Ndumu area.

\section{Description}

SAM-PCZ22282 (Fig. 2I, J) is a fragmentary juvenile with a maximum preserved diameter of $42.5 \mathrm{~mm}$. Coiling is moderately involute, the deep umbilicus comprising $28 \%$ of the diameter, with a high, convex wall and broadly rounded umbilical shoulder. The intercostal whorl section is depressed reniform, the costal whorl section depressed polygonal, with a whorl breadth to height ratio of 1.19 , the maximum breadth at the inner lateral tubercle. There are nine primary ribs on the outer half whorl of the fragment. They arise at the umbilical seam, strengthen and pass straight across the umbilical wall, and progress into well-developed bullae, perched on the umbilical shoulder. The bullae give rise to single strong, straight, narrow, prorsiradiate ribs that link to a subequal inner lateral bulla, from which the ribs pass straight across the outer flanks, ventrolateral shoulders and venter, bearing small bullate inner ventrolateral tubercles, and outer ventrolateral clavi. Single shorter ribs intercalate, and bear inner and outer ventrolateral clavi. Towards the adapertural end of the fragment, the inner ventrolateral clavi decline and are absent on the three adapertural ribs. SAM-PCZ22415 is a $180^{\circ}$ body chamber fragment with a maximum preserved diameter of $83 \mathrm{~mm}$, and a poorly preserved nucleus. Coiling is involute, the deep umbilicus comprising approximately $26 \%$ of the diameter. The costal whorl breadth to height ratio is estimated at 1.25 . There are16 ribs at the ventrolateral shoulder of the fragment. Primary ribs arise at the umbilical seam and are strongly developed on the umbilical wall and shoulder, where they strengthen into small umbilical bullae. A strong, straight prorsiradiate rib links to a stronger inner lateral bulla, and to a weaker outer ventrolateral tubercle, the outer ventrolateral tubercles connected across the venter by a strong transverse rib. Single long or short ribs intercalate between the primaries, and strengthen to match them on the outer flanks, ventrolateral shoulders and venter. OUM KX10397 (Fig. 2A) is a near-complete adult with an original estimated diameter of $95 \mathrm{~mm}$, retaining a $180^{\circ}$ sector of body chamber. Coiling becomes progressively more evolute around the outer whorl. On the phragmocone and adapical part of the body chamber, the ornament is as in the previous specimen, with coarse primary ribs with umbilical bullae, stronger inner lateral tubercles and weaker outer ventrolateral tubercles, alternating with one or two long or short intercalated ribs. This style of ornament modifies on the adapertural $60^{\circ}$ sector of the body chamber; the umbilical and inner lateral tubercles weaken and are lost, the last few ribs weakening, crowding and becoming feebly flexuous.

\section{Discussion}

The present specimens find a match within the variable, dimorphic English material described by Wright \& Kennedy (1984). SAM-PCZ22282 (Fig. 2I, J) corresponds to the original of their pl. 25, fig. 1; SAM-PCZ22415 to their pl. 25, fig. 6 and OUM KX10397 (Fig. 2A) to their pl. 20, fig. 3. The distinctive features of Mantelliceras cantianum are the massive, slightly compressed to slightly depressed whorls, inner lateral tubercles stronger than the umbilical, the latter strengthening through ontogeny, early loss of inner ventrolateral tubercles, and persistence of the outer. It differs from Mantelliceras mantelli, as discussed above, in which umbilical, lateral, inner and outer ventrolateral tubercles persist to the end of the phragmocone, producing a distinctive polygonal whorl section.

\section{Occurrence}

Lower Cenomanian, Mantelliceras mantelli and M. dixoni zones. The geographic distribution extends from southern England across France, northern Spain, Germany, Switzerland, Romania (?), Iran, central Tunisia, KwaZulu-Natal in South Africa, Madagascar, and Japan.

\section{Mantelliceras picteti Hyatt, 1903}

Figs 2B, 7E-F, M-O, R-T, 22B

1859 Ammonites Mantelli Sowerby; Pictet \& Campiche, p. 200, pl. 26, fig. 3, ? figs1, 2

1903 Mantelliceras picteti Hyatt, p. 114 [pars].

1984 Mantelliceras picteti Hyatt, 1903; Wright \& Kennedy, p. 117, pl. 27, figs 1-5; pl. 28, figs 1-3; text-figs 25g, 27i, $\mathrm{n}-\mathrm{q}$ (with full synonymy).

1985 Mantelliceras tenue Spath; Immel \& Seyed-Emami, p. 100 , pl. 4, fig. 7 .

1986 Mantelliceras picteti Hyatt; Kennedy, Juignet \& Wright, p. 35, figs 8d-e, 9, 10a-c, 11a-d.

1988 Mantelliceras picteti Hyatt; Avram, Draganescu, Szasz \& Neagu, pl. 7, fig. 7; pl. 8, fig. 1.

1972 Mantelliceras picteti Hyatt; Thomel, pl. 2, fig. 1; pl. 26, fig. 4; pl. 27, fig. 1; pl. 28, fig. 8.

1997 Mantelliceras picteti Hyatt, 1903; Arkadiev \& Bogdanova, p. 127 , pl. 46, fig. 3.

1998 Mantelliceras cf. picteti Hyatt, 1903; Lehmann, p. 21.

2000 Mantelliceras picteti Hyatt, 1903; Arkadiev, Atabekian, Baraboshkin \& Bogdanova, p. 114, pl. 10, fig. 4. 
?2005 Mantelliceras cf. picteti Hyatt, 1903; Matsumoto \& Toshimitsu, p. 32, text-fig. 3.

2013 Mantelliceras picteti Hyatt, 1903; Kennedy, Walaszczyk, Gale, Dembicz \& Praszkier, p. 638, p. 7, figs 5, 6, 7; text-fig. $4 a, b$.

Type

The lectotype, by the subsequent designation of Wright \& Kennedy 1984, p. 118, is the original of Pictet \& Campiche 1859, pl. 26, fig. 3 from the Cenomanian of Sainte Croix, Vaud, Switzerland.

\section{Material}

OUM KX10310, from locality 61, bed 3, OUM KX14570, from locality 62 , OUM KX14567, 14569 from locality 61 , OUM KX10388a-c from locality 183 OUM KX10409 from locality 185. SAM-PCZ22280, from the Ndumu area, all from the Lower Cenomanian part of the Mzinene Formation.

Dimensions

\begin{tabular}{|c|c|c|c|c|c|}
\hline & $\mathrm{D}$ & $\mathrm{Wb}$ & Wh & Wb:Wh & $\mathrm{U}$ \\
\hline OUM KX14567C & $\begin{array}{c}44.8 \\
(100)\end{array}$ & $\begin{array}{c}19.9 \\
(44.4)\end{array}$ & $\begin{array}{c}20.7 \\
(46.2)\end{array}$ & 0.96 & $\begin{array}{c}10.9 \\
(24.3)\end{array}$ \\
\hline
\end{tabular}

\section{Description}

The original figure of the lectotype shows a specimen $57.5 \mathrm{~mm}$ in diameter with a compressed whorl section. There are an estimated 30 ribs on the outer whorl, 15 of which are primaries with weak umbilical bullae, stronger lateral bullae, feebly clavate inner ventrolateral tubercles and stronger outer ventrolateral clavi, linked across the venter by a low rib. There are also primary ribs without umbilical bullae, and shorter intercalated ribs that lack a lateral tubercle.

KwaZulu specimens are mostly fragments that overlap in size with the lectotype, with whorl heights of up to $30 \mathrm{~mm}$, and costal whorl breadth to height ratios of up to 0.97 , the ornament of predominantly primary ribs with umbilical bullae, with subsidiary non-bullate primaries and long intercalated ribs, as in the lectotype. OUM KX14567 (Fig. 7M-O), although worn, is a complete internal mould of a phragmocone $42.3 \mathrm{~mm}$ in diameter, with 14 primary ribs with umbilical bullae, and a total of an estimated 28-33 ribs at the ventrolateral shoulder. OUM KX14569 (Fig. 7R-T) is interpreted as a finely ornamented juvenile, with a maximum preserved diameter of $27 \mathrm{~mm}$. OUM KX11521 (Fig. 7E, F) is a well-preserved internal mould of an individual with a maximum diameter of $45.5 \mathrm{~mm}$, septate to a diameter of $38 \mathrm{~mm}$. The ornament on the phragmocone corresponds to that of other KwaZulu fragments of comparable size, but the body chamber shows a weakening and loss of the lateral bullae and weakening of the inner ventrolateral tubercles, suggesting the specimen to be an incomplete small adult, perhaps a microconch. SAM-PCZ22280 shows similar ontogenetic changes on the body chamber at a comparable whorl height.

\section{Discussion}

The well-preserved KwaZulu specimens differ in no significant respects from the holotype of Mantelliceras antanimangaense Collignon, 1964 (p. 83, pl. 346, fig. 1539;
Fig. 6 herein), from the Lower Cenomanian of Antanimanga (Mandabe, Madagascar), which, following Wright \& Kennedy (1984, p. 118) is a synonym. OUM KX14567 (Fig. 7M-O) corresponds to another Madagascan species, Mantelliceras patens Collignon, 1964 (p. 87, pl. 347, fig. 1546), which is a further synonym of picteti.

\section{Occurrence}

Mantelliceras picteti ranges throughout the Lower Cenomanian. There are records from southern England, France from the Boulonnais to Sarthe, Argonne, Isère and Provence, Germany, northern Spain, Switzerland, Podolia, Crimea, Iran, KwaZulu-Natal, and Madagascar.

\section{Mantelliceras couloni (d'Orbigny, 1850)}

Fig. 5C, D

1841 Ammonites Mantelli Sowerby; d'Orbigny, p. 340 [pars], pl. 104, figs1-4.

1850 Ammonites Couloni d'Orbigny, p. 147.

1984 Mantelliceras couloni (d'Orbigny, 1850); Wright \& Kennedy, p. 119, pl. 21, fig. 1; pl. 23, figs 5, 6; pl. 29, figs 1-3; pl. 30, figs 1, 2; pl. 31, figs 3-5; pl. 36, fig. 5; text-figs 25f, h; 27a-d (with full synonymy).

1991 Mantelliceras cf. couloni (d'Orbigny, 1850); Matsumoto \& Toshimitsu, p. 2, pl. 1, figs a, b.

1996 Mantelliceras couloni (d'Orbigny, 1850); Kennedy in Gale, Kennedy, Burnett, Caron \& Kidd, p. 563, textfigs $15 \mathrm{a}, 19 \mathrm{k}$.

1997 Mantelliceras couloni (d'Orbigny); Wilmsen, pl. 23, fig. 4.

2005 Mantelliceras cf. couloni (d'Orbigny, 1850); Matsumoto \& Toshimitsu, p. 31, figs 1a, b.

2006 Mantelliceras couloni (d'Orbigny, 1850); Kennedy \& Juignet in Gauthier, p. 125, pl. 51, figs 1-3.

Type

The lectotype, designated by Juignet \& Kennedy (1976, p. 95) is no. R8011 (formerly 18961-27) in the collections of the Muséum National d'Histoire Naturelle, Paris, from the Lower Cenomanian of Lamnay, Sarthe, France. It was refigured by, amongst others, Wright \& Kennedy (1984, text-fig. 20G-I) and Kennedy \& Juignet in Gauthier (2006, pl. 51, fig. 1).

\section{Material}

SAM-PCZ22417, from the Lower Cenomanian part of the Mzinene Formation in the Ndumu area.

\section{Description}

The specimen is a half whorl, almost entirely phragmocone, $67 \mathrm{~mm}$ in diameter, retaining extensive areas of the original aragonitic shell. Coiling is moderately evolute, the umbilicus comprising $24 \%$ of the diameter, shallow, with a feebly convex, subvertical wall and broadly rounded umbilical shoulder. The whorl section is compressed, with a costal whorl breadth to height ratio of 0.8 , the greatest breadth around mid-flank, the flanks feebly convex, subparallel, the ventrolateral shoulders broadly rounded, the venter feebly convex in intercostal section. An estimated 12 primary ribs arise at the umbilical seam of the outer half whorl, and strengthen into weak to barely differentiated umbilical bullae. These give rise to straight prorsiradiate ribs, whilst 
long and short ribs intercalate, to give a total of 17 ribs at the ventrolateral shoulder. They all bear a feeble umbilical bulla that weakens progressively and an inner ventrolateral bulla that is barely detectable at the greatest preserved diameter, together with stronger, persistent outer ventrolateral clavi, linked across the venter by a broad transverse rib, the costal section feebly concave between the clavi.

\section{Discussion}

The combination of compressed whorl section, weak to obsolete umbilical and inner ventrolateral bullae and strong outer ventrolateral clavi characterize this distinctive species. The present specimen retains traces of inner ventrolateral tubercles to a greater diameter than some,but not all French and English specimens referred to the species. Mantelliceras couloni differs from the compressed Mantelliceras saxbii (Sharpe, 1857) ( p. 45, pl. 20, fig. 3; see revision in Wright \& Kennedy 1984 , p. 121 , pl. 23, fig. 4; pl. 32, figs $1-3$; pl. 33, figs $1-4$; pl. 34, figs $1-4$; pl. 35, figs $1-5$; pl. 36, figs 2 , 3 ; pl. 39 , fig. 1 ; text-figs $25 \mathrm{~b}-\mathrm{d}, \mathrm{i} ; 26 \mathrm{~b} ; 28 \mathrm{l}-\mathrm{p}$ ) most obviously in the lack of a lateral tubercle at all ontogenetic stages, and the presence of strong outer ventrolateral clavi throughout most of the ontogeny.

\section{Occurrence}

Lower Cenomanian, southern England, northwestern and southeastern France, Iran, Romania (?), Japan, and northern KwaZulu-Natal.

\section{Mantelliceras saxbii (Sharpe, 1857)}

Fig. 7K, L

1857 Ammonites Saxbii Sharpe, p. 45, pl. 20, fig. 3.

1984 Mantelliceras saxbii (Sharpe, 1857); Wright \& Kennedy, p. 121, pl. 23, fig. 4; pl. 32, figs 1-3; pl. 33, figs 1-4; pl. 34, figs 1-4; pl. 35, figs 1-5; pl. 36, figs 2, 3; pl. 39, fig. 1; text-figs 25b-d, i; 26b; 28I-p (with full synonymy).

1998 Mantelliceras saxbii (Sharpe, 1857); Kaplan, Kennedy, Lehmann \& Marcinowski, p. 118, pl. 18, figs 1, 9; pl. 20, fig. 1; pl. 24, fig. 3; pl. 26, figs 7, 8; pl. 41, figs 2, 4 (with additional synonymy).

1998 Mantelliceras saxbii (Sharpe, 1857); Lehmann, p. 21, pl. 2, fig. 6 .

?2003 Mantelliceras saxbii (Sharp) [sic]; Kawabe, Takashima, Wani, Nishi \& Moriya, pl. 2, fig. 1.

?2005 Mantelliceras saxbii (Sharpe, 1857); Aly, Abdel-Gawad \& Gabir p. 370, pl. 7, fig.2 only, non 3.

2011 Mantelliceras saxbii (Sharpe, 1857); Mosavina and Wilmsen, p. 182, text-fig. 4c, f, g (with additional synonymy).

2013 Mantelliceras saxbii (Sharpe, 1857); Wilmsen, Storm, Fürsich \& Majidifard, text-fig. 8.

2013 Mantelliceras saxbii (Sharpe, 1857); Kennedy, Walaszczyk, Gale, Dembicz \& Praszkier, p. 637, pl. 4, figs 3-6; textfig. 4c, d, g.

2014 Mantelliceras saxbii (Sharpe, 1857); Walaszczyk, Kennedy, Dembicz, Gale, Praszkier, Rasoamiaramanana, Randrianaly, p. 110, fig. 24h.

\section{Lectotype}

By the subsequent designation of Wright \& Wright 1951, p. 38 , is no. 7763 in the collections of the British Geological Survey, the original of Sharpe 1857, pl. 20, fig. 3, refigured by
Wright \& Kennedy (1984, pl. 35, fig. 2), from the Lower Cenomanian 'Grey Chalk of Ventnor', Isle of Wight, U.K.

\section{Material}

SAM-PCZ22418 (Fig. 7K, L), from the Lower Cenomanian part of the Mzinene Formation of the Skoenberg.

\section{Description}

The specimen is an internal mould with an original estimated diameter of $40 \mathrm{~mm}$. Coiling is involute, the shallow umbilicus comprising $23 \%$ of the diameter, with a low, convex wall and quite narrowly rounded umbilical shoulder. The whorl section is compressed, with feebly convex, subparallel flanks, broadly rounded ventrolateral shoulders, and a very feebly convex venter. Eight primary ribs per half whorl arise at the umbilical seam, strengthen across the umbilical wall and develop into small umbilical bullae. The bullae give rise to single straight prorsiradiate primary ribs, separated by one or two long or short intercalated ribs. On the adapical part of the outer whorl, the primary ribs bear a feeble lateral bulla, and all ribs bear a feeble inner ventrolateral bulla and a stronger outer ventrolateral clavus, the clavi linked over the venter by a broad, transverse rib. Both lateral and inner ventrolateral bullae weaken progressively and are absent from the adapertural $120^{\circ}$ body chamber sector, the outer ventrolateral tubercles persisting.

\section{Discussion}

Mantelliceras saxbii most closely resembles Mantelliceras couloni (d'Orbigny, 1850); differences between the two are set out under that species.

\section{Occurrence}

Mantelliceras saxbii ranges throughout the Lower Cenomanian, but is common only in the middle of the substage, being represented by rather stout forms in the lower part of its range and by densely and flexuously ribbed forms in the upper part. It is widespread in southern England, the Boulonnais, Haute Normandie, Maine, Sarthe and Provence in France, northern Spain, Switzerland, Poland, Romania, Bulgaria, Koppeh Dagh, Transcaspia, Iran north of the Zagros, Kazakhstan, north Africa, Angola, KwaZulu-Natal in South Africa, Madagascar, and Japan.

\section{Mantelliceras dixoni Spath, 1926b}

Fig. 3A-C, L, M

1850 Ammonites Milletianus ?d'Orbig.; J. de C. Sowerby in Dixon, p. 359, pl. 29, fig. 15

1926b Mantelliceras dixoni Spath, pp. 427, 430.

1984 Mantelliceras dixoni Spath, 1926b; Wright \& Kennedy, p. 124, pl. 37, figs 1-6; pl. 38, figs 2-5; pl. 39, figs 2-5; pl. 40, figs 1-5; text-figs 21d-f; 22a-g; 23; 25e, j; 27m, r, $\mathrm{s}$ (with full synonymy).

1998 Mantelliceras dixoni Spath, 1926b; Kaplan, Kennedy, Lehmann \& Marcinowski, p. 122, pl. 20, figs 4, 5; pl. 23, figs 1-7; pl. 24, figs 7-9; pl. 54, fig. 2 (with additional synonymy)

1998 Mantelliceras dixoni (Spath, 1926b); Lehmann, p. 22, pl. 3, fig. 2 .

1999 Mantelliceras dixoni Spath; Gale, Hancock \& Kennedy, pl. 1, figs 9-11. 
?2005 Mantelliceras cf. dixoni Spath, 1926; Matsumoto \& Toshimitsu, p. 35, text-fig. 4.

?2013 Mantelliceras dixoni (?) Spath; Reboulet, Giraud, Colombié \& Carpentier, text-fig. 4e.

2013 Mantelliceras dixoni Spath, 1926; Kennedy, Walaszczyk, Gale, Dembicz \& Praszkier, p. 639, pl. 4, figs 1, 2; text-fig. 5.

2014 Mantelliceras dixoni Spath, 1926; Walaszczyk, Kennedy, Dembicz, Praszkier, Rasoamiaramanana \& Randrianaly, p. 109, fig. 23a, b.

Type

The holotype, by original designation, is BMNH C33630, from the Lower Chalk of Sussex, the original of J. de C. Sowerby in Dixon, 1850, pl. 29, fig. 12, refigured by Wright \& Kennedy, (1984, pl. 37, fig. 6).

\section{Material}

OUM KX4671, collected loose, but inferred to be from the Lower Cenomanian part of the Mzinene Formation at locality 62 of Kennedy \& Klinger (1975). OUM KX14454, from bed 14 of the Lower Cenomanian part of the Mzinene Formation at locality 61 of Kennedy \& Klinger (1975), the western 'horn' of the Skoenberg.

\section{Dimensions}

\begin{tabular}{|l|c|c|c|c|c|}
\hline & $\mathrm{D}$ & Wb & Wh & Wb:Wh & U \\
\hline OUM KX4671c & $\begin{array}{c}40.6 \\
(100)\end{array}$ & $\begin{array}{c}18.5 \\
(45.6)\end{array}$ & $\begin{array}{c}19.7 \\
(48.5)\end{array}$ & 0.94 & $\begin{array}{c}9.9 \\
(24.4)\end{array}$ \\
\hline
\end{tabular}

\section{Description}

OUM KX4671 (Fig. 3A-C) is a worn phragmocone that retains recrystallized shell. Coiling is involute, with approximately $57 \%$ of the previous whorl covered. The umbilicus is of moderate depth, and comprises $24 \%$ of the diameter, with a low, flattened wall and broadly rounded umbilical shoulder. The whorl section is compressed, with flattened, subparallel inner and middle flanks, convergent outer flanks, broadly rounded umbilical shoulders and a flattened venter in intercostal section. The costal whorl breadth to height ratio is 0.94 . There are an estimated 14 primary ribs on the outer whorl. They arise at the umbilical seam, and are strong and crowded on the umbilical wall and shoulder, strengthening into strong umbilical bullae. These give rise to single strong, straight prorsiradiate ribs that link to a well-developed inner lateral bulla, best seen on the penultimate whorl, and the least-worn parts of the outer whorl (Fig. 3B). There are also primary/long intercalated ribs that lack these tubercles, and shorter intercalated ribs to give an estimated total of 32 ribs at the ventrolateral shoulder. All bear well-developed outer ventrolateral clavi, linked across the venter by a strong transverse rib. OUM KX14454 (Fig. 3L, M) is a fragmentary body chamber with a maximum preserved diameter of $74 \mathrm{~mm}$, the primary ribs strongly developed on the inner flank of the adapical part, where they arise both singly and in pairs, with one or two intercalated ribs. The venter is only preserved on the adapertural part of the specimen, and lacks tubercles.

\section{Discussion}

OUM KX4671 closely resembles the holotype (Wright \& Kennnedy1984, pl. 37, fig. 6), while the larger fragment finds a match in the original of Wright \& Kennedy 1984 pl. 38, fig. 1. The distinguishing features of Mantelliceras dixoni are the rounded whorl section, primary ribs with umbilical and inner lateral tubercles linked by a strong rib to weak inner ventrolateral tubercles, outer ventrolateral clavi lost on the adult body chamber, all characters shown by the present specimens.

\section{Occurrence}

The species is restricted to the upper Lower Cenomanian Mantelliceras dixoni Zone of the northwest European sequence. Its presence in situ at the highest level exposed at locality 61 on the Skoenberg is an important indicator for the presence of the upper Lower Cenomanian in the Mzinene Formation there. There are also records from southern England, the Boulonnais, Haute Normandie, Sarthe, Jura, Basses Alpes, and Bouches-du-Rhône in France, Germany, Switzerland, Romania, Iran north of the Zagros(?), northern Mexico, El Salvador, Japan (?), and Madagascar.

\section{Mantelliceras lateretuberculatum Collignon, 1964}

Figs $5 E-G, 22 A$

1964 Mantelliceras lateretuberculatum Collignon, p. 90, pl. 348, fig. 1548.

1964 Mantelliceras alternans Collignon, p. 97, pl. 351, fig. 1557.

1976 Mantelliceras lateretuberculatum Collignon; Juignet \& Kennedy, p. 90 (pars), pl. 16, fig. 2 only. non pl. 15, figs 1, 2; pl. 22, figs 1, 2 (= M. dixoni)

non 1979 Mantelliceras lateretuberculatum Collignon; Wiedmann \& Schneider, p. 668, pl. 10, fig. 1; text-fig. 10a $(=M$. dixoni $)$.

non 1982 Mantelliceras lateretuberculatum Collignon 1964; Hiss, p. 1998, text-figs 9.6, 9.7 (= ?M. picteti).

\section{Name of the species}

We regard lateretuberculatum and alternans of Collignon to be synonyms, and as first revising authors, select lateretuberculatum as the name of the species.

Type

The holotype, by monotypy, is the original of Collignon, 1964, p. 90, pl. 348, fig. 1548, from the Lower Cenomanian of Collignon's gisement 426, south of the Col du Vohimaranitra (Betioky), Madagascar, housed in the collections of the Université de Bourgogne, Dijon.

\section{Material}

SAM-PCZ22416, from the Lower Cenomanian part of the Mzinene Formation in the Ndumu area. OUM KX10389, from the Lower Cenomanian (Cenomanian II) at locality 183 of Kennedy \& Klinger (1975), also in the Ndumu area.

\section{Description}

SAM-PCZ22416 (Fig. 5E-G) is a complete adult with an estimated original diameter of $85 \mathrm{~mm}$. Coiling is involute, the umbilicus comprising $27 \%$ of the diameter, of moderate 
depth, with a feebly convex subvertical wall and broadly rounded umbilical shoulder. On the phragmocone, the costal whorl section is slightly depressed polygonal, with the greatest breadth at the lateral tubercle. Fourteen ribs arise at the umbilical seam, strengthen across the umbilical wall and shoulder, and develop into progressively strengthening umbilical bullae. These give rise to single straight prorsiradiate ribs that strengthen and coarsen across the flanks and bear strong, subspinose lateral bullae, weaker roundedclavate inner ventrolateral tubercles and slightly stronger outer ventrolateral clavi. Single long intercalated ribs arise low on the flanks, across which they strengthen, but do not develop a lateral tubercle, having inner and outer ventrolateral tubercles that match those on the primary ribs. A broad, blunt rib links the outer ventrolateral clavi across the venter. This pattern of ornament persists onto the adapical part of the body chamber. On the adapertural part, the umbilical bullae weaken markedly, the lateral tubercles efface and are lost; weakened inner and outer ventrolateral tubercles persisting to the adult aperture. OUM KX10389 (Fig. 22A) preserves one flank of the body chamber of a comparable individual with an estimated diameter of $70 \mathrm{~mm}$, showing the same weakening and loss of tuberculation.

\section{Discussion}

The KwaZulu specimens differ in no significant respects from the holotype (Collignon, 1964, p. 90, pl. 348, fig. 1548). The distinctive features of Mantelliceras lateretuberculatum are the alternation of primary and long intercalated ribs, the former with subspinose lateral bullae, the latter lacking lateral bullae, together with the weakening and loss of umbilical and lateral tuberculation but persistence of inner and outer ventrolateral tubercles on the adult body chamber. These features are shared by the holotype of Mantelliceras alternans Collignon, 1964 (p. 97, pl. 351, fig. 1557), which we believe to be a synonym.

\section{Occurrence}

Lower Cenomanian of Madagascar and northern KwaZuluNatal.

\section{Mantelliceras nitidum (Crick, 1907)}

Fig. 4A-D, G-L

1907 Acanthoceras nitidum Crick, p. 201, pl. 12, fig. 4.

1971 Calycoceras nitidum (Crick); Kennedy, pl. 44, fig. 3.

?1972 Calycoceras (Gentoniceras) nitidum (Crick); Thomel, p. 70 , pl. 24, figs 5,6 .

?non 1976 Calycoceras aff. nitidum (Crick)?; Juignet \& Kennedy, p. 112, pl. 25, fig. 5 (= Calycoceras (Gentoniceras) $\mathrm{sp}$

1990 Acanthoceras nitidum Crick, 1907; Wright \& Kennedy, text-fig. 91c-e.

non 2001 Calycoceras nitidum (Crick, 1907); Aly \& AbdelGawad, p. 33, pl. 3, fig. 2

\section{Types}

The holotype (Fig. 4A-D) is BMNH C18211, the original of Crick 1907, p. 201, pl. 12, fig. 4, from the 'deposit at the north end of False Bay', that is to say the Skoenberg. Paratypes are BMNH C18212 (Fig. 4G, K, L) and C18313.

Dimensions
\begin{tabular}{|l|c|c|c|c|c|}
\hline & D & Wb & Wh & Wb:Wh & U \\
\hline BMNH C18211 & $\begin{array}{c}37.3 \\
(100)\end{array}$ & $\begin{array}{c}20.9 \\
(56.0)\end{array}$ & $\begin{array}{c}17.5 \\
(46.9)\end{array}$ & 1.19 & $\begin{array}{c}9.6 \\
(25.7)\end{array}$ \\
\hline SAM-PCZ13470 & $\begin{array}{c}51.6 \\
(100)\end{array}$ & $\begin{array}{c}30.0 \\
(58.1)\end{array}$ & $\begin{array}{c}24.8 \\
(48.1)\end{array}$ & 1.21 & $\begin{array}{c}13.1 \\
(25.4)\end{array}$ \\
\hline
\end{tabular}

\section{Description}

The holotype (Fig. 4A-D) is a phragmocone $37.3 \mathrm{~mm}$ in diameter. Coiling is moderately evolute, the umbilicus small, and of moderate depth. The umbilical wall is feebly convex, the umbilical shoulder broadly rounded. The whorl section is depressed, ovoid in intercostal section, the greatest breadth around mid-flank. Fifteen to sixteen primary ribs arise at the umbilical seam, strengthen across the umbilical wall, and develop into small umbilical bullae. These give rise to single primary ribs, with one, rarely, two long or short intercalated ribs between, to give a total of $\sim 30$ ribs per whorl at the ventrolateral shoulder. The primary ribs bear a small inner lateral tubercle to a diameter of about $32 \mathrm{~mm}$, beyond which the inner part of the rib remains thickened, and bar-like. There is a small inner ventrolateral tubercle to a diameter of $26 \mathrm{~mm}$, thereafter lost, and a small, persistent outer ventrolateral clavus. The clavi are linked across the venter by a well-developed transverse rib. BMNH C18312 (Fig. 4G, K, L) is the larger paratype fragment mentioned by Crick (1907, p. 202), a $120^{\circ}$ whorl fragment of phragmocone with a maximum preserved whorl height of $24.5 \mathrm{~mm}$. Bullate primary ribs alternate regularly with single intercalated ribs. The ribs are crowded, straight and prorsiradiate on the flanks, transverse on the venter, with effacing ventral tubercles. Paratype BMNH C18212 (Fig. 4E, F) is a juvenile $18.2 \mathrm{~mm}$ in diameter with umbilical, inner and outer ventrolateral and siphonal tubercles, the primary ribs separate by one or two short intercalated ribs. It is ajuvenile Calycoceras (Newboldiceras) sp.

SAM-PCZ13470 (Fig. 4H-J) is a $51.6 \mathrm{~mm}$ diameter phragmocone with recrystallized shell preserved. The whorl section is depressed reniform, with a whorl breadth to height ratio of 1.21. There are an estimated 42 ribs at the ventrolateral shoulder, with primary ribs separated by one or two intercalated ribs. At the beginning of the outer whorl, the primary ribs bear small umbilical, inner lateral, inner and outer ventrolateral tubercles. The lateral tubercles efface after a few ribs, as do the inner ventrolateral, while the outer ventrolaterals are lost on the last few ribs.

\section{Discussion}

The distinctive features of Mantelliceras nitidum are the depressed reniform whorl section, early loss of inner lateral and inner ventrolateral tubercles, followed by the loss of the outer ventrolateral. The early developmental stages with a full complement of tubercles resemble those of Mantelliceras cantianum, described above, but that species is coarsely ribbed, and retains umbilical bullae, coarser inner lateral tubercles and outer ventrolateral clavi to the end of the phragmocone. Mantelliceras lymense (Spath, 1926b) (p. 427, 431; see revision in Wright \& Kennedy1984, p. 102 , pl. 10, fig. 9; p. 22, figs 1-6; pl. 23, figs1-3; pl. 31, figs 1 , 2; pl. 36, fig. 4; text-figs 19, 24a,b; 26d; 28f-j) lacks 
a lateral tubercle, and has minute outer ventrolateral tubercles that may be lost for a phase of development.

\section{Occurrence}

The species in known only from material from the Skoenberg, none of it collected in situ. It is assumed to be an Early Cenomanian species, possibly from the upper Lower Cenomanian.

\section{Genus Utaturiceras Wright, 1956}

\section{Type species}

Ammonites vicinalis Stoliczka, 1864, p. 84, pl. 44, figs 1, 4, $5,7,8$, non $2,3,6$, by the original designation of Wright, 1956 , p. 392 .

\section{Diagnosis}

Medium-sized, compressed, involute; delicate umbilical bullae giving rise to crowded flexuous ribs, singly or in pairs, with long intercalatories. In juveniles, all ribs bear feeble inner ventrolateral tubercles and stronger outer ventrolateral clavi, the former declining in later growth stages. Suture with one or more auxiliary lobes (modified after Wright \& Kennedy 1984, p. 399).

\section{Occurrence}

Lower Cenomanian, South India, Madagascar, northern KwaZulu-Natal, Japan, Israel, and southern England.

\section{Utaturiceras vicinale (Stoliczka, 1864)}

Figs 7A-D, 8A-F

1864 Ammonites vicinalis Stoliczka, p. 84, pl. 44, figs 1, 4, 5, 7, 8, non 2, 3, 6 .

1996 Utaturiceras vicinale (Stoliczka, 1964); Wright \& Kennedy, p. 399, pl. 122, fig. 1; text-fig. 156 (with full synonymy).

2003 Utaturiceras vicinale (Stoliczka, 1864); Matsumoto, Nishida \& Toshimitsu, p. 135, text-figs 4, 5.

\section{Types}

The lectotype, by the subsequent designation of Matsumoto \& Sarkar, 1966, p. 298, is no. 190 in the collections of the Geological Survey of India, Kolkata (Calcutta) (Matsumoto \& Sarkar 1966, p. 32, text-fig. 1; Wright \& Kennedy 1996, text-fig. 156), from the Utatur Group of Odium, Tamil Nadu, South India. There are seven paralectotypes, not all of which belong to $U$. vicinale (Matsumoto \& Sarkar, 1966, p. 298).

\section{Material}

SAM-PCZ22419, from locality 183 in the Ndumu area. SAM-PCZ22412, from the Skoenberg. OUM KX10303 and 10312 from bed 3 at locality 181, and OUM KX10404, from locality 185 , both in the Ndumu area.

\section{Dimensions}

\begin{tabular}{|l|c|c|c|c|c|}
\hline & $\mathrm{D}$ & $\mathrm{Wb}$ & Wh & Wb:Wh & $\mathrm{U}$ \\
\hline OUM KX10404c & $\begin{array}{c}45.8 \\
(100)\end{array}$ & $\begin{array}{c}16.7 \\
(36.5)\end{array}$ & $\begin{array}{c}23.5 \\
(51.3)\end{array}$ & 0.71 & $\begin{array}{c}8.2 \\
(17.9)\end{array}$ \\
\hline OUM KX10303 & $\begin{array}{c}61.0 \\
(100)\end{array}$ & $\begin{array}{c}\sim 21.3 \\
(34.9)\end{array}$ & $\begin{array}{c}33.1 \\
(54.3)\end{array}$ & $\sim 0.64$ & $\begin{array}{c}9.5 \\
(15.6)\end{array}$ \\
\hline
\end{tabular}

\section{Description}

OUM KX10404 (Fig. 8D-F) is a well-preserved phragmocone retaining original aragonitic shell, $45.8 \mathrm{~mm}$ in diameter. Coiling is involute, with $80 \%$ of the previous whorl covered. The umbilicus is small ( $17.9 \%$ of the diameter), shallow, with a low, feebly convex, outward-inclined wall and quite narrowly rounded umbilical shoulder. The whorl section is compressed, with a costal whorl breadth to height ratio of 0.71 , the greatest breadth below mid-flank. The inner flanks are feebly convex, subparallel, the outer flanks convergent, the ventrolateral shoulders broadly rounded in intercostal section, the venter feebly convex. Twelve primary ribs arise at the umbilical seam, and are well developed on the umbilical wall and shoulder, where they strengthen into small umbilical bullae. These give rise to single ribs, or a pair of ribs, while one or two long or short ribs intercalate, to give a total of an estimated 30-32 ribs at the ventrolateral shoulder. The ribs are low, strengthening progressively across the flanks, straight to midflank, where they flex back and are feebly concave on the outer flank, broadening progressively, and linking to feeble inner ventrolateral bullae, linked by a strong prorsiradiate rib to stronger outer ventrolateral clavi. The clavi are linked across the venter by a broad, transverse rib. SAM-PCZ 22419 (Fig. 7D) is a slightly crushed individual with a maximum preserved diameter of $40 \mathrm{~mm}$, with slightly coarser ornament. SAM-PCZ22412 (Fig. 7A-C) is a half whorl of phragmocone $52 \mathrm{~mm}$ in diameter, with a whorl breadth to height ratio of 0.75 . The fragment retains recrystallized shell, with ribbing comparable to that of OUM KX10404 on the flanks, the umbilical bullae more conspicuous, and projecting into the umbilicus. The inner ventrolateral tubercles efface progressively. OUM KX10303 (Fig. 8A-C) is a phragmocone $61 \mathrm{~mm}$ in diameter, worn on one flank, but with original aragonitic shell surviving on the figured side. Coiling is very involute, the umbilicus comprising $15.6 \%$ of the diameter, shallow, with a feebly convex, outwardinclined umbilical wall and narrowly rounded umbilical shoulder on the penultimate whorl that broadens on the outer whorl of the specimen. The approximate whorl breadth to height ratio is 0.64 , a degree of compression exaggerated by wear on one flank. There are 16 ribs at the ventrolateral shoulder of the outer half whorl. Most of the ribs are primaries, arising from the umbilical shoulder with or without developing into a small umbilical bulla. They are straight and feebly prorsiradiate on the inner flank, flexing back at mid-flank, broadening, and feebly concave on the outer flank. There are small, clearly differentiated inner ventrolateral tubercles and stronger outer ventrolateral clavi at the beginning of the outer whorl; the former weaken and decline progressively, and are near effaced at the greatest preserved diameter.

\section{Discussion}

Utaturiceras discoidale (Kossmat, 1895) (p. 210 (105), pl. 25 (11), fig. 1; see also Matsumoto, Nishida \& Toshimitsu 2003, p. 138), from the Lower Cenomanian Utatur Group of Odium, South India, differs from $U$. vicinale in its much more evolute coiling, stouter whorl section, and coarser, distant ribs, of which there are 34 on the outer whorl, with strong inner and outer ventrolateral tubercles retained to 
maturity. Utaturiceras chrysanthemum (see also Matsumoto, Nishida \& Toshimitsu 2003, p. 138, figs 6-8) is less compressed than $U$. vicinale, with an oval rather than rectangular-trapezoidal whorl section, much coarser, distant, flexuous ribs, the umbilical bullae effacing on the body chamber and the inner and outer ventrolateral tubercles merging.

\section{Occurrence}

Lower Cenomanian of South India, Madagascar, northern KwaZulu-Natal, and southern England.

\section{Genus Submantelliceras Spath, 1923}

\section{Type species}

Ammonites aumalensis Coquand, 1862, p. 172, pl. 1, figs 27,28 , by the original designation of Spath, 1923, p. 143.

\section{Diagnosis}

Dwarf mantelliceratine with umbilical bullae that give rise to one or two primary ribs, with additional short intercalated ribs; all ribs bear inner and outer ventrolateral tubercles. Adult body chambers show decline and loss of tubercles, ribs crowding and forming ventral chevron with rounded peak on adapertural part.

\section{Discussion}

The type species of Submantelliceras has generally been regarded as the nucleus of some larger mantelliceratine. Hancock, Kennedy \& Cobban (1993, p. 462) concluded that the holotype of Mantelliceras brazoense Böse, 1928 (p. 220, pl. 6, figs 5-43), from the Lower Cenomanian Del Rio Clay of Texas was conspecific with the holotype of Submantelliceras aumalense (Coquand, 1862) (p. 172, pl. 1, figs 27, 28), the type species of Submantelliceras. Kennedy (in Kennedy, Cobban, Hancock \& Gale, 2005, p. 386) described and illustrated the type material of aumalense (p. 388, text-fig. $25 \mathrm{a}-\mathrm{z}$ ), and demonstrated that brazoense represented the inner whorls of Graysonites lozoi Young, 1958, the type species of Graysonites Young, 1958. If correct, Graysonites is a junior synonym of Submantelliceras. That the limonitic nuclei from the Del Rio Clay of Texas might be referred to Submantelliceras was already suggested by Adkins (1928, p. 239), and Mancini (1978, 1982), while Immel \& SeyedEmami (1985) referred wooldridgei of Young, based on adult individuals, to Submantelliceras. Previous authors have, however, overlooked the key observation made by Pervinquière (1907, p. 297, text-fig. 114) on a specimen of aumalense $11 \mathrm{~mm}$ in diameter, which shows crowding and interfering sutures, indicating it to be the phragmocone of an adult. As Pervinquière concluded: 'Il me parait probable que nous avons affair ici à des races naines.' In other words, the type species of Submantelliceras is a paedomorphic dwarf. This is now confirmed on the basis of a comparison of the lectotype of aumalense (refigured by Kennedy, Cobban, Hancock \& Gale, 2005, text-fig. 25a-e) and a specimen from the Lower Cenomanian M. mantelli Zone Marnes de Ballon of Sarthe, France, $16.4 \mathrm{~mm}$ in diameter (Fig. 9A-D) that preserves part of the adult body chamber on which the ventrolateral tuberculation is lost, the ribs strengthening, concave, and projecting forwards on the outermost flank and ventrolateral shoulder and crossing the venter in a shallow convexity. Adult specimens of Acanthoceras (Mammites) prenodosoides Boule, Lemoine \& Thévenin, 1907 ( p. 13 (33), pl. 2 (9), figs 3-5) from northern KwaZulu Natal are described below that are diminutive as adults, and show comparable changes on the adult body chamber as are shown by the Sarthe specimen referred to aumalense; we conclude that it too is a Submantelliceras.

\section{Occurrence}

Lower Cenomanian, Algeria, Tunisia, KwaZulu-Natal, Sarthe in France, and, possibly, southern England.

\section{Submantelliceras prenodosoides (Boule, Lemoine \&} Thévenin, 1907)

Figs $9 \mathrm{E}-\mathrm{R}, 10 \mathrm{~A}-\mathrm{Z}^{\prime}, 11 \mathrm{~A}-\mathrm{O}$

1907 Acanthoceras (Mammites) prenodosoides Boule, Lemoine \& Thévenin, p. 13 (33), pl. 2 (9), figs 3-5.

1929 Acanthoceras (Mammites) prenodosoides Boule, Lemoine \& Thévenin; Collignon, p. 14 (38), pl. 18 (4), figs 1,2

non 1933 Mammites prenodosoides Boule, Lemoine \& Thévenin; Collgnon, p. 68, pl. 6, fig. 4; text-fig. 6

1977 'Mammites' prenodosoides Boule, Lemoine \& Thévenin; Kanie, Hirano \& Tanabe, pl. 2, fig. 6.

Types

Boule, Lemoine \& Thévenin (1907, p. 13(33), pl. 2 (9), figs $3-5$ ) figured three specimens that they referred to this species (1907, p. 13 (33), pl. 2 (9), figs 3-5). We have not seen the originals, and refrain from designating a lectotype until their current status is determined. They were from the Cenomanian of Betaitra, Madagascar.

\section{Material}

SAM-PCZ21245-48, 21252-3, 21258, 21260, 21261, 21263, 21268, 21286, 21291, 21306-8, and 21310-11, ex Van Hoepen Collection, inferred to be from the Lower Cenomanian part of the Mzinene Formation, and from locality 62 of Kennedy \& Klinger (1975), the eastern 'horn' of the Skoenberg. OUM KX11669, 11690, 11692a-b, 11694a-b, 11697-99, 11703-4, 10709-10, from bed 6 of the Lower Cenomanian part of the Mzinene Formation at locality 61 of Kennedy \& Klinger (1975), on the western 'horn' of the Skoenberg. SAM-PCZ22413, from the Lower Cenomanian part of the Mzinene Formation in the environs of Ndumu. OUM KX10297, 10301, 10305-6, 10308, 10314, 10315a-d, 10364, from bed 3 of the Lower Cenomanian Mzinene Formation at locality 181 of Kennedy \& Klinger (1975), Ndumu.

\section{Dimensions}

\begin{tabular}{|l|c|c|c|c|c|}
\hline & $\mathrm{D}$ & $\mathrm{Wb}$ & $\mathrm{Wh}$ & Wb:Wh & $\mathrm{U}$ \\
\hline OUM KX10315a c & $\begin{array}{c}18.8 \\
(100)\end{array}$ & $\begin{array}{c}7.7 \\
(41.0)\end{array}$ & $\begin{array}{c}8.8 \\
(46.8)\end{array}$ & 0.88 & $\begin{array}{c}5.7 \\
(30.3)\end{array}$ \\
\hline SAM-PCZ21307c & $\begin{array}{c}20.3 \\
(100)\end{array}$ & $\begin{array}{c}9.2 \\
(45.3)\end{array}$ & $\begin{array}{c}10.1 \\
(49.8)\end{array}$ & 0.91 & $\begin{array}{c}6.2 \\
(30.5)\end{array}$ \\
\hline SAM-PCZ21311C & $\begin{array}{c}24.2 \\
(100)\end{array}$ & $\begin{array}{c}8.7 \\
(36.0)\end{array}$ & $\begin{array}{c}10.5 \\
(43.4)\end{array}$ & 0.83 & $\begin{array}{c}6.3 \\
(26.0)\end{array}$ \\
\hline SAM-PCZ21261C & $\begin{array}{c}24.5 \\
(100)\end{array}$ & $\begin{array}{c}10.3 \\
(42.0)\end{array}$ & $\begin{array}{c}12.2 \\
(49.8)\end{array}$ & 0.84 & $\begin{array}{c}5.7 \\
(23.3)\end{array}$ \\
\hline
\end{tabular}




\begin{tabular}{|l|c|c|c|c|c|}
\hline OUM KX11692a & $\begin{array}{c}29.5 \\
(100)\end{array}$ & $-(-)$ & $\begin{array}{c}13.2 \\
(44.7)\end{array}$ & - & $\begin{array}{c}8.2 \\
(27.8)\end{array}$ \\
\hline OUM KX11699c & $\begin{array}{c}35.0 \\
(100)\end{array}$ & $\begin{array}{c}12.2 \\
(34.9\end{array}$ & $\begin{array}{c}14.0 \\
(40.0)\end{array}$ & 0.87 & $\begin{array}{c}9.3 \\
(26.6)\end{array}$ \\
\hline
\end{tabular}

\section{Description}

Small, the largest complete adults, interpreted as macroconchs, are up to $35 \mathrm{~mm}$ diameter, the smallest, interpreted as microconchs, are as little as $26.5 \mathrm{~mm}$ diameter. On phragmocones and the adapical part of the adult body chamber, coiling is moderately involute, the umbilicus comprising $26-30 \%$ of the diameter, of moderate depth, with a feebly convex wall and broadly rounded umbilical shoulder. The intercostal whorl section is compressed, with feebly convex flanks, broadly rounded ventrolateral shoulders, and a very feebly convex venter. The costal whorl section is also compressed, with whorl breadth to height ratios of 0.83-0.91, the greatest breadth at the umbilical bullae. Ten ribs per whorl arise at the umbilical seam, and are weak on the umbilical wall, strengthening into strong bullae, perched on the umbilical shoulder. They give rise to single coarse, straight, prorsiradiate ribs, or, occasionally, a pair of ribs, with single ribs intercalating, to give a total of 20 ribs at the ventrolateral shoulder, where all ribs bear coarse rounded-bullate inner ventrolateral tubercles, linked by a coarse, prorsiradiate rib to strong outer ventrolateral clavi, linked over the venter by a low, broad, transverse rib. On adult body chambers, additional ribs may intercalate on the adapical part. On the adapertural part, the ornament is markedly modified. The umbilical bullae and inner ventrolateral tubercles decline and efface, the ribs crowd, weaken, and become markedly flexuous. The outer ventrolateral clavi decline, and give rise to strongly prorsiradiate ribs that broaden across the venter into a feebly obtuse linguoid ventral chevron. Suture moderately incised, with broad, bifid E/A, narrow, bifid A, large, bifid A/U2.

\section{Discussion}

Submantelliceras aumalense differs from S. prenodosoides in its more involute coiling, feeble umbilical tuberculation, and weak flank ornament.

\section{Occurrence \\ Lower Cenomanian of Madgascar and northern KwaZulu- Natal.}

\section{Genus Sharpeiceras Hyatt, 1903}

\section{Type species}

Ammonites laticlavius Sharpe, 1855, p. 31, pl. 14, fig. 1, by original designation of Hyatt, 1903, p. 111.

\section{Diagnosis}

Evolute, whorl section compressed oval or rectangular to quadrate; ribs fine to coarse, typically but not invariably single, normally with umbilical, mid-lateral and inner and outer ventrolateral tubercles through most of ontogeny, but the mid-lateral may weaken and disappear and a fifth, outer lateral, and even a sixth may appear on outer whorls; the two ventrolateral tubercles may amalgamate to form a large horn on outer whorls. Suture with long, more or less symmetrically bifid first lateral lobe and wide, subquadrate saddles (modified after Wright \& Kennedy 1984, p. 126).

\section{Occurrence}

Lower Cenomanian, rare but widespread, throughout Europe, north, south and east Africa, Madagascar, the Middle East, southern India, Japan, Texas and Mexico.

\section{Sharpeiceras laticlavium (Sharpe, 1855)}

Fig. 12R

1855 Ammonites laticlavius Sharpe, p. 31, pl. 14, fig. 1.

1987 Sharpeiceras laticlavium (Sharpe, 1855); Wright \& Kennedy, p. 127, pl. 41, fig. 4; text-figs 29, 30, 34a (with full synonymy).

1991 Sharpeiceras laticlavium (Sharpe, 1855); Delamette \& Kennedy, p. 454, figs 9.9, 9.10.

1994 Sharpeiceras laticlavium (Sharpe, 1855); Kennedy, p. 224.

1996 Sharpeiceras laticlavium (Sharpe); Marcinowski, Walaszczyk \& Olszewska-Nejbert, pl. 13.

1998 Sharpeiceras laticlavium (Sharpe, 1855); Kaplan, Kennedy, Lehmann \& Marcinowski. p. 126, pls 27-30.

2005 Sharpeiceras laticalvium [sic] (Sharpe, 1855); Aly, Abdel-Gawad \& Gabir, p. 373, pl. 8, fig. 2; pl. 9, fig. 1; text-fig. 4 d.

2010 Sharpeiceras laticlavium (Sharpe, 1855); Amédro \& Robaszynski, p. 13, pl. 1, fig. 1

2012 Sharpeiceras laticlavium (Sharpe, 1855); Amédro, Matrion, Touch \& Verrier, p. 11, pl. 3, fig. 2.

Holotype

By monotypy, no. 7755 in the collections of the British Geological Survey, from the Lower Chalk of Bonchurch, Isle of Wight, the original of Sharpe, 1855, pl. 14, fig. 1.

\section{Material}

OUM KX10396, from the Lower Cenomanian Mzinene Formation at locality 183 of Kennedy \& Klinger (1975), $500 \mathrm{~m}$ WSW of Ndumu Police Station.

\section{Description}

OUM KX10396 consists of one flank of a specimen with an an estimated original diameter of $100 \mathrm{~mm}$, the outer $180^{\circ}$ body chamber. Coiling is evolute, the umbilicus shallow, with a low, flattened subvertical wall, the umbilical shoulder quite narrowly rounded. The flank is flat. On the outer whorl, 27 ribs arise at the umbilical seam, and strengthen across the umbilical wall, where they are strong, coarse, and crowded. They develop into progressively strengthening umbilical bullae, that give rise to single low, coarse, straight, feebly prorsiradiate ribs with progressively strengthening rounded-bullate lateral tubercles, and stronger bullate inner ventrolateral tubercles. The greater part of the venter is not preserved, apart from a well-developed outer ventrolateral clavus on the first rib of the outer whorl.

\section{Discussion}

The flattened flank, high whorl, and dense ornament of straight primary ribs separate this specimen from all other Sharpeiceras from KwaZulu-Natal. Although incomplete it 
differs in no significant respects from the holotype (Wright \& Kennedy 1987, pl. 41, fig. 4).

\section{Occurrence}

Lower Cenomanian of southern England, northern, western and southeastern France, Switzerland, Romania Tunisia, Israel, Lebanon, Iran, Madagascar, and northern KwaZuluNatal.

\section{Sharpeiceras falloti (Collignon, 1931)}

Figs 13A-E, I, 14A-V

1931 Acanthoceras (Mantelliceras) falloti Collignon, p. 81 (61), pl. 8 (4), figs 11. 12, non 9, 10.

1987 Sharpeiceras falloti (Collignon, 1931); Wright \& Kennedy, p. 129

non 2013 Sharpeiceras falloti (Collignon, 1931); Kennedy, Walaszczyk, Gale, Dembicz \& Praszkier, p. 642, pl. 5, figs 1-14 (=Sharpeiceras australe Kennedy, 2014).

Type

The lectotype, by the subsequent designation of Wright \& Kennedy 1987, p. 129, is the original of Collignon 1931, pl. 8 (4), fig. 11, from the Cenomanian of the Skoenberg, in the Fallot Collection, housed in the collections of the Institut de Géologie de Nancy. Of the three paralectotypes, the original of Collignon's pl. 8 (4), fig. 12, and also from the Skoenberg, is conspecific. The remaining two paratypes, the originals of Collignon 1931, pl. 8 (4), figs 9, 10, from the presumed Lower Cenomanian of the valley of the Betaitra in northern Madagascar, are juveniles of Sharpeiceras australe Kennedy, 2014. Kennedy (in Kennedy, Walaszczyk, Gale, Dembicz \& Praszkier, 2013, p. 642, pl. 5, figs 1-14) designated the original of Collignon 1931, pl. 8 (4), fig. 10 lectotype of falloti, having overlooked the previous designation of Wright \& Kennedy (1987).

\section{Material}

SAM-PCZ21304-5, OUM KX4725-33, all collected loose, derived from the Lower Cenomanian part of the Mzinene Formation at locality 62 of Kennedy \& Klinger (1975), the eastern 'horn' of the Skoenberg.

\section{Dimensions}

\begin{tabular}{|l|c|c|c|c|c|}
\hline & $\mathrm{D}$ & $\mathrm{Wb}$ & $\mathrm{Wh}$ & $\mathrm{Wb}: W h$ & $\mathrm{U}$ \\
\hline OUM KX4725c & $\begin{array}{c}30.4 \\
(100)\end{array}$ & $\begin{array}{c}11.0 \\
(36.2)\end{array}$ & $\begin{array}{c}13.1 \\
(43.1)\end{array}$ & 0.84 & $\begin{array}{c}9.9 \\
(32.6)\end{array}$ \\
\hline OUM KX4731c & $\begin{array}{c}31.3 \\
(100)\end{array}$ & - & $\begin{array}{c}12.5 \\
(39.9)\end{array}$ & - & $\begin{array}{c}11.8 \\
(37.7)\end{array}$ \\
\hline OUM KX4729c & $\begin{array}{c}33.4 \\
(100)\end{array}$ & $\begin{array}{c}13.0 \\
(38.9)\end{array}$ & $\begin{array}{c}13.7 \\
(41.1)\end{array}$ & 0.95 & $\begin{array}{c}11.0 \\
(32.9)\end{array}$ \\
\hline SAM-PCZ21304c & $\begin{array}{c}36.2 \\
(100)\end{array}$ & $\begin{array}{c}13.8 \\
(38.1)\end{array}$ & $\begin{array}{c}14.7 \\
(40.6)\end{array}$ & 0.94 & $\begin{array}{c}14.1 \\
(39.0)\end{array}$ \\
\hline
\end{tabular}

\section{Description}

Specimens vary from 21 to $41 \mathrm{~mm}$ in diameter, with a larger fragment OUM KX4730 (Fig. 14C-E, N, O) with a maximum preserved whorl height of $22.2 \mathrm{~mm}$, corresponding to an estimated diameter of $55 \mathrm{~mm}$. The early develop- mental stages are well shown by SAM-PCZ21304 (Fig. 13AD). Coiling is very evolute, the umbilicus comprising $39 \%$ of the diameter, shallow, with a low, feebly convex, outward-inclined umbilical wall and broadly rounded umbilical shoulder. The intercostal whorl section is slightly compressed, oval, with feebly convex flanks, broadly rounded ventrolateral shoulders and a convex venter. The penultimate whorl of this specimen has 14 primary ribs. They arise at the umbilical seam, strengthen across the umbilical wall, developing into small bullae, perched on the umbilical shoulder. These give rise to low, broad, straight, prorsiradiate ribs, while additional ribs intercalate, to give a total of 20 ribs at the ventrolateral shoulder, where all bear a rounded-conical inner ventrolateral tubercle. There are 20 ribs on the outer whorl of this specimen, strong and coarse on the umbilical wall, developing into sharp bullae, displaced outwards from the umbilical shoulder to the innermost flank, and giving rise to a strong prorsiradiate rib that connects to a strong conical inner ventrolateral tubercle and a strong outer ventrolateral clavus. OUM KX4729 (Fig. 14I-L, S-U) has comparable ornament on the penultimate whorl, but an initially tiny, but progressively strengthening, lateral tubercle appears at the beginning of the outer whorl of this $33 \mathrm{~mm}$ diameter nucleus. SAM-PCZ21305 (Fig. 13E, I) lacks a lateral tubercle at the greatest preserved diameter of $21 \mathrm{~mm}$; it is poorly expressed in OUM KX4731 (Fig. 14A, B, R) at a diameter of $31 \mathrm{~mm}$. In the largest specimen, OUM KX4730 (Fig. 14C-E, N, O), the ornament is stronger than in the previous specimens. A lateral tubercle is present at a whorl height of $6-7 \mathrm{~mm}$ (Fig. 14N, O). On the outer whorl of this fragment, the ribs are strong, high, and distant, well developed on the umbilical wall, the bulla displaced out to an umbilico-lateral position, close to a much stronger lateral tubercle, from which it is barely differentiated. There are strong subspinose conical inner and outer ventrolateral tubercles, the latter closely spaced on either side of the venter, which is deeply concave between.

\section{Discussion}

These nuclei are distinguished by their evolute coiling, the late acquisition of a lateral tubercle, the very strong lateral tubercle by comparison with the umbilical once developed, the progressive assimilation of the umbilical bulla into the lateral tubercle in the largest specimen, and the strong, subspinose inner and outer ventrolateral tubercles. These features readily distinguish it from the nuclei of Sharpeiceras australe Kennedy, 2014 at a comparable diameter (Collignon 1931, pl. 8, figs 9, 10; Kennedy in Kennedy et al., 2013, pl. 5, figs 6-8). Wright \& Kennedy (1987, p. 129) included in their interpretation of Sharpeiceras falloti material described below as Sharpeiceras minor sp. nov. A comparison of the largest individuals referred to falloti (the lectotype, and the original of Fig. 14C-E, N, O) with specimens of minor sp. nov. of comparable size (for example Figs 12A-F, 15A, D-G) convinces us that they are different. Sharpeiceras minor $\mathrm{sp}$. nov. has the umbilical and lateral tubercles clearly differentiated, the conical inner ventrolateral tubercles much stronger than the outer ventrolateral clavi, the reverse of the case in falloti, where they become conical and subspinose. Wright \& Kennedy (1987, p. 109) considered Sharpeiceras kongo 
Matsumoto, Muramoto \& Takahashi, 1969 (p. 261, pl. 29, fig. 1 ; pl. 30 , fig. 1 ; text-figs 3,4 ) to be an adult of the present species. The Japanese species is known only from large individuals up to $300 \mathrm{~mm}$ in diameter, and comparison with the present material is not really possible. We note that the umbilical and lateral tubercles remain clearly differentiated in kongo, and doubt that it is a synonym of falloti.

\section{Occurrence}

Lower Cenomanian of northern KwaZulu-Natal.

\section{Sharpeiceras mocambiquense (Choffat, 1903)}

Fig. 13F-H

1903 Acanthoceras laticlavium (Sharpe) var. moçambiquensis Choffat, p. 25, pl. 4, fig. 3; pl. 7, fig. 1.

1987 Acanthoceras laticlavium var. moçambiquensis Choffat; Wright \& Kennedy, p. 127.

1998 Sharpeiceras mocambiquense (Choffat); Matsumoto \& Toshimitsu, p. 624, pls 2, 3.

1999 Sharpeiceras mocambiquense (Choffat); Matsumoto, Hayakawa \& Toshimitsu, p. 19, text-fig. 1.

2004 Sharpeiceras mocambiquense (Choffat, 1903); Matsumoto, Nishida \& Toshimitsu, p. 80, text-fig. 19.

2013 Sharpeiceras mocambiquense (Choffat, 1903); Kennedy, Walaszczyk, Gale, Dembicz \& Praszkier, p. 640, pl. 4, figs 8,9 ; pl. 6, fig. 2.

\section{Type}

The holotype, by monotypy, is the original of Choffat, 1903, p. 25, pl. 4, fig. 3; pl. 7, fig. 1, from the Cenomanian of Conducia in northern Mozambique.

\section{Material}

OUM KX5789, collected loose at locality 62 of Kennedy \& Klinger (1975), the eastern 'horn' of the Skoenberg, and inferred to be derived from the Lower Cenomanian part of the Mzinene Formation.

\section{Dimensions}

\begin{tabular}{|c|c|c|c|c|c|}
\hline & D & Wb & Wh & Wb:Wh & $U$ \\
\hline OUM KX5789 & $\begin{array}{c}66.9 \\
(100)\end{array}$ & $\begin{array}{c}17.6 \\
(26.3)\end{array}$ & $\begin{array}{c}28.3 \\
(42.3)\end{array}$ & 0.62 & $\begin{array}{c}24.0 \\
(35.9)\end{array}$ \\
\hline
\end{tabular}

\section{Description}

The specimen is a worn fragment of phragmocone retaining calcite-replaced shell, with an estimated original diameter of $67 \mathrm{~mm}$. Coiling is very evolute, the umbilicus shallow, with a low, flattened, outward-inclined wall and broadly rounded shoulder. The whorl section is very compressed, oval in intercostal section with feebly convex subparallel flanks, broadly rounded ventrolateral shoulders and a narrow, feebly convex venter. The costal whorl breadth to height ratio is 0.62 , the greatest breadth just below mid-flank. There are 15 primary ribs on the outer half whorl of the fragment. They arise at the umbilical seam, and are coarse, crowded, and separated by narrower interspaces. They strengthen into feeble bullae, perched on the umbilical shoulder. These give rise to single straight prorsiradiate ribs that strengthen progressively across the flanks and bear weak mid- and outer lateral bullae, stronger conical inner ventrolateral tubercles, and strong, high, outer ventrolateral clavi.

\section{Discussion}

Although worn, the very compressed whorl section immediately separates this specimen from other Sharpeiceras in the present collection. The presence of a fifth, outer lateral tubercle is obvious only on the adapertural end of one flank (Fig. 13F), as a result of wear. The compressed whorl section and five rows of tubercles on each flank are characters shown only by Sharpeiceras mocambiquensis (Choffat, 1903, p. 25, pl. 4, fig. 3; pl. 7, fig. 1). The holotype is a large individual, $450 \mathrm{~mm}$ in diameter. The inner whorls are poorly preserved, but show, on the umbilical shoulder and innermost flank, the same crowded ribbing as the present specimen. A worn phragmocone $200 \mathrm{~mm}$ in diameter from Madagascar, figured and described by Matsumoto, Hayakawa \& Toshimitsu (1999, p. 17, figs 1, 2) has comparable dense, crowded ribbing, albeit at a greater diameter than the present specimen. As noted elsewhere (Kennedy, Walaszczyk, Gale, Dembicz \& Praszkier 2013, p. 641), the Sharpeiceras aff. schlueteri of Hayakawa \& Takahashi (2000, pls 1, 2; text-fig. 2) has five rows of tubercles and a very compressed whorl section (the whorl breadth to height ratio is 0.48 according to their text-figure), and appears closer to the present species than to Hyatt's species. Sharpeiceras kikuae Matsumoto \& Kawashita, 1996 (in Nishida, et al. 1996; see also Matsumoto \& Kawashita 1998, p. 92, text-figs 3, 4) from the Lower Cenomanian of Hokkaido, Japan, has five rows of tubercles, but is very evolute, the whorls expanding more slowly than in the present species, the ribs coarse and distant, with a maximum of 12 ribs per half whorl. Sharpeiceras australe Kennedy, 2014, discussed further below, is a small species, the whorls lower, slowly expanding, with coarser, more distant ribs.

\section{Occurrence}

Lower Cenomanian of northern Mozambique, northern KwaZulu-Natal, Madagascar, and Japan.

\section{Sharpeiceras minor sp. nov.}

Figs 12A-I, L-O, 13J-M, 15A-I, 16A-E, 17A-E, 18

\section{Types}

The holotype is SAM-PCZ21296 (Fig. 15H, I); paratypes are SAM-PCZ21269, 21283, 21292, 21297, 21301, and 21302, ex Van Hoepen Collection, from the Lower Cenomanian Mzinene Formation of the Skoenberg. Paratypes OUM KX11627, 11654 and 11655, are from the Lower Cenomanian of bed 6 of the Mzinene Formation at locality 61 of Kennedy \& Klinger (1975), on the western 'horn' of the Skoenberg. Paratypes OUM KX10277, 10283, 10290, 10293, $10295,10309,10321-2$, and 10324 are from bed 3 of the Mzinene Formation at locality 181 of Kennedy \& Klinger (1975), south of Ndumu.

\section{Material}

SAM-PCZ21264, 21270-21282, 21284, 21285, 2128721290, 21293-21294, 21299-21300, 21303, from the Lower Cenomanian of the Skoenberg, ex Van Hoepen Collection. 
OUM KX11635, 11636, 11682-4, from locality 61 , bed 6 of the Lower Cenomanian Mzinene Formation at locality 61 of Kennedy \& Klinger (1975) on the western 'horn' of the Skoenberg.

Dimensions

\begin{tabular}{|l|c|c|c|c|c|}
\hline & $\mathrm{D}$ & Wb & Wh & $\begin{array}{c}\text { Wb: } \\
\text { Wh }\end{array}$ & $U$ \\
\hline SAM-PCZ21277c & $\begin{array}{c}36.7 \\
(100)\end{array}$ & $\begin{array}{c}16.9 \\
(46.0)\end{array}$ & $\begin{array}{c}17.7 \\
(48.2)\end{array}$ & 0.95 & $\begin{array}{c}9.7 \\
(26.4)\end{array}$ \\
\hline SAM-PCZ21297c & $\begin{array}{c}39.3 \\
(100)\end{array}$ & $\begin{array}{c}14.9 \\
(37.9)\end{array}$ & $\begin{array}{c}17.3 \\
(44.0)\end{array}$ & 0.86 & $\begin{array}{c}10.4 \\
(26.5)\end{array}$ \\
\hline OUM KX11627c & $\begin{array}{c}55.1 \\
(100)\end{array}$ & $\begin{array}{c}25.2 \\
(45.7)\end{array}$ & $\begin{array}{c}25.5 \\
(46.3)\end{array}$ & 0.99 & $\begin{array}{c}18.4 \\
(33.4)\end{array}$ \\
\hline SAM-PCZ21301C & $\begin{array}{c}69.6 \\
(100)\end{array}$ & $\begin{array}{c}29.4 \\
(42.2)\end{array}$ & $\begin{array}{c}28.8 \\
(41.4)\end{array}$ & 1.02 & $\begin{array}{c}22.8 \\
(32.8)\end{array}$ \\
\hline SAM-PCZ21296c & $\begin{array}{c}86.9 \\
(100)\end{array}$ & $\begin{array}{c}32.3 \\
(37.2)\end{array}$ & $\begin{array}{c}35.0 \\
(40.3)\end{array}$ & 0.92 & $\begin{array}{c}26.8 \\
(30.8)\end{array}$ \\
\hline OUM KX10283a C & $\begin{array}{c}98.2 \\
(100)\end{array}$ & $-(-)$ & $\begin{array}{c}36.8 \\
(37.5\end{array}$ & - & $\begin{array}{c}35.1 \\
(35.7)\end{array}$ \\
\hline
\end{tabular}

\section{Diagnosis}

A small, evolute species of Sharpeiceras, macroconchs up to $98 \mathrm{~mm}$ in diameter, microconchs $45-63 \mathrm{~mm}$ in diameter, Coarse ribs bear umbilical, lateral, inner and outer ventrolateral tubercles, the inner conical ventrolaterals stronger than the outer ventrolateral clavi.

\section{Description}

Coiling is very evolute, with around $30 \%$ of the previous whorl covered. The expansion rate is low. The umbilicus is broad, up to $33.4 \%$ of the diameter on phragmocones, increasing to $35.5 \%$ in adults, shallow, with a convex wall and broadly rounded umbilical shoulder, the intercostal whorl section is oval, varying from slightly compressed to slightly depressed, with convex, subparallel flanks, broadly rounded ventrolateral shoulders and a broad, feebly convex venter. The costal whorl section is polygonal, with whorl breadth to height ratios varying from 0.86 to 1.02 , the greatest breadth at the lateral tubercles. There are 17-20 ribs per whorl at the ventrolateral shoulder. They arise at the umbilical seam, strengthen across the umbilical wall and develop into strong umbilical bullae. On phragmocones, these give rise to coarse, straight prorsiradiate ribs, with strong lateral bullae from a diameter of around $15 \mathrm{~mm}$, and rounded-bullate inner ventrolateral tubercles that give rise to a prorsiradiate rib that sweeps forwards across the ventrolateral shoulder and link to strong outer ventrolateral clavi from the smallest diameters seen. There are occasional long or short intercalated ribs, with lateral, inner and outer ventrolateral tubercles, or inner and outer ventrolaterals only. The profile of the ribs is markedly concave between the tubercles. On adult body chambers, all of the ribs are primaries, with strong tuberculation, the inner ventrolateral strengthened into horns, and much stronger than the outer ventrolateral clavi. The tuberculation weakens markedly on the last few ribs, and the lateral tubercles are near-effaced on the rib preceding the adult aperture. The holotype (Fig. 15H, I), retains the adult aperture, and is interpreted as a macroconch, $87 \mathrm{~mm}$ in diameter. Paratype SAM-PCZ21292
(Fig. 15B, C) is a further adult, near-complete at $87.1 \mathrm{~mm}$ diameter, as is OUM KX10283a, $97.7 \mathrm{~mm}$ in diameter (Fig. 18). Specimens interpreted as microconchs include OUM KX10283b (Fig. 17A), KX10290 (Fig. 16C-E), KX10321 (Fig. 17B, C) and SAM-PCZ21298 (Fig. 12L, M), and range between 45 and $63 \mathrm{~mm}$ in diameter. The weakening and loss of lateral and inner ventrolateral tubercles is more pronounced on the last few ribs preceding the adult aperture than it is in macroconchs.

\section{Discussion}

Small adult size, combined with evolute coiling and slowly expanding whorls with coarse ribbing and tuberculation separate Sharpeiceras minor from Sharpeiceras florencae, small specimens (Figs 7G, H, I, J, P, Q, U; 12J, K, P, Q) are more involute, with compressed rectangular whorls, a higher expansion rate, and more delicate ribs and tubercles. Sharpeiceras falloti, described above, is known from nuclei only (Figs 13A-E, 14A-V). These are even more evolute than those of the present species, slowly expanding, with both inner and outer ventrolateral tubercles spinose, the outer stronger than or equal to the inner, whereas in the present species the inner are stronger than the outer, which are clavi, rather than spines. Sharpeiceras australe Kennedy, 2014 (introduced as nomen novum for Sharpeiceras falloti of Kennedy in Kennedy, Walaszczyk, Gale, Dembicz \& Praszkier 2013, p. 642, pl. 5, figs 1-14, non Collignon, 1931) is a species of comparable adult size and strength of ornament, but is immediately separable on the basis of the presence of a fifth row, of outer lateral tubercles, on the later phragmocone whorls and the body chamber.

\section{Occurrence}

Lower Cenomanian of northern KwaZulu-Natal.

\section{Sharpeiceras florencae Spath, 1925}

Figs 7G-J, P, Q, U, V, W, 12J, K, P, Q, 16F-H, 17F-I, 19-21, $22 \mathrm{C}-\mathrm{E}$

1925 Sharpeiceras florencae Spath, p. 198, pl. 37.

1933 Sharpeiceras florencae Spath; Collignon, p. 67, pl. 6, fig. 5.

1956 Sharpeiceras occidentale Benavides-Cáceres, p. 465, pl. 54, figs 5, 6 .

1959 Sharpeiceras florencae Spath; Matsumoto, pp. 69, 70; text-fig. 28.

1962 Tlahualiloceras tlahualiloense Kellum \& Mintz, p. 276, pl. 6, fig. 1; pl. 7, figs 1, 2; pl. 8, fig. 1.

1964 Sharpeiceras schlueteri Hyatt; Collignon, p. 102, pl. 354, fig. 1565.

1964 Sharpeiceras vohipalense Collignon, p. 104, pl. 354, fig. 1565.

non 1971 Sharpeiceras florencae Spath; Kennedy, p. 67, pl. 25, fig. 2.

1985 Sharpeiceras florencae Spath; Howarth, p. 86, textfigs 15-19.

1998 Sharpeiceras florencae Spath, 1925; Matsumoto \& Toshimitsu, p. 622, pl. 1 (with additional synonymy).

2011 Sharpeiceras florencae Spath, 1925; Meister, Buta, David \& Tavares, p. 695, pl. 25, fig. 1; pl. 26, figs 1, 2; pl. 27 , fig. 1 ; pl. 28, fig. 1; pl. 29, fig. 1; pl. 30, fig. 1; pl. 31, fig. 1; pl. 32, figs 1, 2; pl. 33, figs 1, 2; pl. 34, figs 1, 2; pl. 35, figs 1, 2; pl. 36, fig. 2; pl. 37, fig. 1. 
?2011 Sharpeiceras florencae crassum Meister, Buta, David \& Tavares, p. 697, pl. 22, fig. 1; pl. 23, figs 1, 2; pl. 24, fig. 1

?2013 Sharpeiceras cf. florencae Spath, 1925; Kennedy, Walaszczyk, Gale, Dembicz \& Praszkier, p. 641, pl. 6, fig. 1.

\section{Type}

The holotype, by monotypy, is the original of Spath, 1925 , p. 19, pl. 37, in the collections of the Ditsong Museum of Natural History (formerly the Transvaal Museum), Pretoria, from northeastern KwaZulu-Natal (Maputoland).

\section{Material}

OUM KX10292, 10322, 10278-10282, 10284-10288, SAM-PCZ5831, 7391, 22422, and 21312 from bed 3 of the Lower Cenomanian Mzinene Formation at locality 175 of Kennedy \& Klinger (1975) in the Ndumu area. SAMPCZ21295, 22411, and OUM KX4727, collected loose, believed to be derived from the Lower Cenomanian part of the Mzinene Formation at locality 62 of Kennedy \& Klinger (1975), the eastern 'horn' of the Skoenberg.

\section{Dimensions}

\begin{tabular}{|l|c|c|c|c|c|}
\hline & $\mathrm{D}$ & Wb & Wh & Wb:Wh & $\mathrm{U}$ \\
\hline SAM-PCZ22411c & $\begin{array}{c}31.1 \\
(100)\end{array}$ & - & $\begin{array}{c}16.4 \\
(52.7)\end{array}$ & - & $\begin{array}{c}6.8 \\
(21.9)\end{array}$ \\
\hline OUM KX10285a c & $\begin{array}{c}39.8 \\
(100)\end{array}$ & - & $\begin{array}{c}19.4 \\
(48.7)\end{array}$ & - & $\begin{array}{c}11.6 \\
(29.1)\end{array}$ \\
\hline SAM-PCZ21245c & $\begin{array}{c}40.4 \\
(100)\end{array}$ & $\begin{array}{c}18.8 \\
(46.5)\end{array}$ & $\begin{array}{c}18.9 \\
(46.8)\end{array}$ & 0.99 & $\begin{array}{c}10.5 \\
(26.0)\end{array}$ \\
\hline OUM KX10286 & $\begin{array}{c}63.2 \\
(100)\end{array}$ & $\begin{array}{c}28.8 \\
(45.6)\end{array}$ & $\begin{array}{c}28.4 \\
(0.99)\end{array}$ & 1.01 & $\begin{array}{c}17.3 \\
(27.4)\end{array}$ \\
\hline
\end{tabular}

\section{Description}

The present material consists of a suite of nuclei 31-63 $\mathrm{mm}$ in diameter, and a series of fragments with whorl heights of up to $63 \mathrm{~mm}$. The coiling of nuclei is moderately evolute, with around $40 \%$ of the previous whorl covered, the umbilicus comprising between 22 and $28 \%$ of the diameter, shallow, with a low, convex subvertical wall, and quite narrowly rounded umbilical shoulder. The whorl section is compressed, with flattened, subparallel flanks, broadly rounded ventrolateral shoulders, and a feebly convex venter in intercostal section. The costal section is polygonal with whorl breadth to height ratios of around 1 , the greatest breadth at the lateral tubercle. There are an estimated 12-14 ribs per whorl at the umbilical shoulder, and 24 at the ventrolateral shoulder. Primary ribs arise at the umbilical seam, but are weak on the umbilical wall, but strengthen into well-developed umbilical bullae. These give rise to strong, narrow, straight, prorsiradiate ribs that bear strong lateral bullae and rounded-clavate inner ventrolateral tubercles, connected to slightly stronger outer ventrolateral clavi by a strong, feebly prorsiradiate rib. The clavi are connected across the venter by a low, broad rib. There are a few long ribs that lack a well-developed umbilical bulla, and short intercalated ribs that bear only inner and outer ventrolateral tubercles. Intercalated ribs are prominent in SAM-PCZ22411 (Fig. 7P, Q, U) and SAM-PCZ21295
(Fig. 7G, H), and persist to a diameter of $51 \mathrm{~mm}$ in OUM KX10286 (Fig. 12P, Q). In contrast, they are lost beyond a diameter of $22 \mathrm{~mm}$ in OUM KX10285a (Fig. 12J, K).

Larger fragments are shown in Figs $7 \mathrm{~V}$, W, and 17F-I. Here, the intercostal whorl section is compressed, with intercostal whorl breadth to height ratios of around 0.8 , and costal whorl breadth to height ratios of around 0.9. Ornament is of strong primary ribs that are narrower than the interspaces, strengthen progressively across the flanks, and bear small umbilical bullae, stronger lateral bullae, conical inner ventrolateral tubercles and outer ventrolateral clavi, linked across the venter by a low, broad, transverse rib. Also included in Sharpeiceras florencae are individuals such as SAM-PCZ1283 and OUM KX10282 (Fig. 19), with much more massive whorls, and a costal whorl section that is slightly depressed rather than compressed, the lateral, inner and outer ventrolateral tubercles subspinose.

\section{Discussion}

We have not seen the holotype; a copy of Spath's original illustration is reproduced here as Fig. 20. According to Spath's account, we calculate that the original had a maximum diameter of $219 \mathrm{~mm}$ approximately. Spath described the specimen as having a compressed, relatively flattened whorl section to a diameter of $100 \mathrm{~mm}$, the whorl section as wide as high at a diameter of $200 \mathrm{~mm}$, as a result of the increasing prominence of the lateral tubercle. On the phragmocone, there are 15 ribs on the adapical half of the outer whorl, the ribs broad, crowded, with weak umbilical bullae, stronger lateral bullae, stronger conical inner ventrolateral tubercles, the outer ventrolateral clavi stronger still. The ribbing coarsens at the adapertural end of the phragmocone, and on the body chamber, becoming coarse and distant. Larger fragments such as those illustrated here as Figs $16 \mathrm{H}$ and $18 \mathrm{~F}-\mathrm{H}$, differ in no significant respects from the holotype as figured by Spath. Howarth (1985, p. 86) suggested that Acanthoceras (Mantelliceras) falloti Collignon, 1931, might be a synonym; as described above, we believe it to be a separate species. He also suggested Sharpeiceras goliath Haas, 1942 (p. 7, text-figs 5-7) was a synonym. This species was revised by Meister, Buta, David \& Tavares (2011, p. 600); it is a Late Albian mortoniceratine, assigned to Arestoceras Van Hoepen, 1942, by these authors. Sharpeiceras occidentale Benavides-Cáceres, 1956 (p. 465, pl. 54, figs 5, 6), from the Lower Cenomanian of Peru is interpreted as a relatively weakly tuberculate variant of the present species. Tlahualiloceras tlahualiloense Kellum \& Mintz, 1962 (p. 276, pl. 6, fig. 1; pl. pl. 7, figs 1, 2; pl. 8, fig. 1), from the Lower Cenomanian part of the Indidura Formation of the Sierra de Tlahualilo, Coahuila, northern Mexico, appears to be a further synonym. The original of Sharpeiceras schlueteri Collignon 1964, p. 104, pl. 354, fig. 1565, non Hyatt, 1903, is reillustrated here as Fig. 22D; it is a clear synonym. Sharpeiceras schlueteri Hyatt, 1903, is revised by Kaplan, Kennedy, Lehmann \& Marcinowski (1998, p. 128, pls 31,32 , pl. 33, figs 3,4 ); it is a very evolute species, the intercostal section compressed oval to trapezoidal in early and middle growth, the whorls expanding slowly, with 23-29 ribs per whorl, the number increasing as diameter increases. Most ribs are single, coarse and distant with umbilical and lateral tubercles, inner ventrolateral tuber- 
cles that may become spines and outer ventrolateral clavi. The adult body chamber shows coarsening ornament and the appearance of an outer lateral tubercle at diameters of $290 \mathrm{~mm}$, the ventrolateral tubercles strengthening markedly. The body chamber ornament never reaches the coarseness and wide separation of ribs seen in the present species, whilst $S$. florencae does not, so far as is known, develop a fifth row of tubercles. The holotype of Sharpeiceras vohipalense Collignon, 1964 p. 104, pl. 354, fig. 1565), reillustrated here as Figs 21, 22E, is from the Cenomanian of the Niveau Supérieur of the Collines Vohipaly, Madagascar. It has a maximum diameter of $162 \mathrm{~mm}$ according to Collignon, an intercostal whorl breadth to height ratio of 0.76 and a costal ratio of 0.99 . The specimen retains a $120^{\circ}$ sector of body chamber. There are 24-25 ribs per whorl on the phragmocone, with weak umbilical bullae, stronger rounded-bullate lateral tubercles, stronger rounded-conical inner ventrolateral tubercles, and outer ventrolateral clavi. The ornament coarsens markedly on the body chamber, the ribs becoming distant, the inner ventrolateral tubercle strengthening markedly. The style of ornament is as in the present species, although the phragmocone ornament is weaker; it is here regarded as an intraspecific variant of S. florencae.

\section{Occurrence}

Lower Cenomanian of northern KwaZulu-Natal, Madagascar, Angola, Peru, and northern Mexico.

\section{Sharpeiceras sp. A}

Fig. 5A, B

\section{Material}

OUM KX10304, from bed 3 of the Lower Cenomanian part of the Mzinene Formation at locality 181 of Kennedy \& Klinger (1975) in the Ndumu area.

\section{Description}

The specimen is a fragmentary phragmocone, with a maximum preserved diameter of $75 \mathrm{~mm}$. Coiling is involute, with an estimated $70 \%$ of the previous whorl covered. The small umbilicus comprises an estimated $24 \%$ of the diameter, of moderate depth, with a flattened, subvertical wall, and very narrowly rounded umbilical shoulder. The whorl section is compressed, with a costal whorl breadth to height ratio of 0.8 , the greatest breadth at the umbilical shoulder. The flanks are feebly convex, converging to the broadly rounded ventrolateral shoulders and feebly convex venter in intercostal section. The ventrolateral shoulders and venter are flattened in costal section. Twelve primary ribs arise on the umbilical wall of the outer half whorl of the fragment, and strengthen into small bullae, perched on the umbilical shoulder. The bullae give rise to one or two narrow, straight, prorsiradiate primary ribs, while there are one or two long or short intercalated ribs, to give a total of 18-19 ribs at the ventrolateral shoulder of the outer half whorl. The primary ribs bear feeble mid-lateral bullae, and all ribs bear very feeble, barely detectable outer lateral bullae, close to stronger rounded-clavate inner ventrolateral tubercles, linked by a strong straight rib to subequal feebly clavate outer ventrolateral tubercles, linked across the venter by a broad, transverse rib. The partially exposed suture has a broad, bifid $\mathrm{E} / \mathrm{A}$ and narrow, bifid $\mathrm{A}$.

\section{Discussion}

The whorl section, weak mid-lateral tubercles, presence of an outer lateral row of feeble tubercles, and strong ventral ribs separate this specimen from the superficially similar Sharpeiceras laticlavium, described above. The specimen differs from the juvenile Sharpeiceras mocambiquense described above in the much weaker mid-lateral and outer ventrolateral tuberculation and very compressed whorl section of the latter.

\section{Occurrence}

Lower Cenomanian of northern KwaZulu-Natal.

\section{Sharpeiceras sp. B}

\section{Fig. 23}

\section{Material}

SAM-PCZ19847, from the Lower Cenomanian part of the Mzinene Formation of the Skoenberg, localities 61-62 of Kennedy \& Klinger (1975).

\section{Description}

Parts of two whorls are preserved. The penultimate whorl fragment has a maximum preserved whorl height of $70.5 \mathrm{~mm}$. The umbilicus is small, of moderate depth, the umbilical wall convex, the umbilical shoulder broadly rounded. The whorl section is compressed rectangular, the intercostal whorl breadth to height ratio 0.72 , the greatest breadth just below mid-flank, the flanks very feebly convex, subparallel, the ventrolateral shoulders broadly rounded, the venter feebly convex. Ten small bullae perch on the umbilical shoulder, and give rise to one or two ribs, with one or two long ribs intercalating, to give a total of 18 ribs per half whorl at the ventrolateral shoulder. They are low, prorsiradiate, broadening across the flanks, and bear a weak lateral bulla, strong conical inner ventrolateral tubercles, and strong outer ventrolateral clavi. The ribs become increasingly widely spaced from the adapical to adapertural ends of the fragment. The venter is smooth and concave between the outer ventrolateral clavi. The massive outer $120^{\circ}$ whorl fragment is body chamber, with a maximum preserved intercostal whorl height of $118 \mathrm{~mm}$, and a maximum preserved costal whorl height of $124 \mathrm{~mm}$. The intercostal whorl breadth to height ratio is 0.88 ; the costal whorl breadth to height ratio is 0.86 . Parts of six primary ribs are preserved. They arise at the umbilical seam, and strengthen across the umbilical wall, sweeping back to strong umbilical bullae that give rise to single coarse, very widely separated prorsiradiate straight to feebly concave ribs that strengthen across the flank. The adapical three ribs on the fragment bear a coarse lateral bulla, thereafter lost. The inner and outer ventrolateral tubercles of the penultimate whorl have fused into a massive ventrolateral horn that rises high above the venter, the whorl section concave between the horns.

\section{Discussion}

The specimen bears some resemblance to the holotype of Sharpeiceras mocambiquense, but differs in the lack of a fifth row of tubercles, which persist onto the body cham- 
ber, where the inner and outer ventrolateral tubercles remain separate at a size where they have fused in the present specimen (Choffat, 1903, pl. 4, fig. 3a, b). Given the limited material, we leave it in open nomenclature.

\section{Occurrence}

Lower Cenomanian of northern KwaZulu-Natal.

\section{ACKNOWLEDGEMENTS}

Kennedy acknowledges the support of the staff of the Geological Collections, Oxford University Museum of Natural History, and the Department of Earth Sciences, Oxford, and the financial assistance of the Oppenheimer Fund (Oxford). Klinger acknowledges support of the staff of the Natural History collections Department of Iziko, South African Museum and financial support from the NRF, South Africa. Lehmann was supported by the German Research Foundation (DFG, project LE 1241/2-1) and by SYNTHESYS, financed by European Community Research Infrastructure Action under the FP7 Integrating Activities Programme. We thank Dr John W.M. Jagt for his meticulous review of the manuscript.

\section{REFERENCES}

ADKINS, W.S. 1928. Handbook of Texas Cretaceous fossils. University of Texas Bulletin 2838: 385 pp.

ALY, F., ABDEL-GAWAD, G.I. \& GABIR, M. A. 2005. Uppermost Albian-basal Cenomanian ammonites from North Sinai, Egypt. Egyptian Journal of Palaeontology 5: 347-385.

AMEDRO, F., COBBAN, W. A., BRETON, G. \& ROGRON, P. 2002. Metengonoceras teigenense Cobban et Kennedy, 1989: une ammonite exotique d'origine Nord-Américaine dans le Cénomanien inférieur de Basse-Normandie (France). Bulletin trimestrielle de la Société géologique de Normandie et des Amis du Muséum du Havre 87 (for 2000): 5-25.

AMÉDRO, F., MATRION, B., TOUCH, R. \& VERRIER, J.-M. 2012. Extension d'un niveau repère riche en Inoceramus crippsi [bivalve] dans le Cénomanien basal du Bassin Anglo-Parisien. Annales de la Société géologique du Nord 19: 9-23.

AMÉDRO, F. \& ROBASZYNSKI, F. 2010. La transgression cénomanienne et l'âge des Tourtias, du Nord du Bassin de Paris (F) et du Bassin de Mons (B). Bulletin d'Information des Géologues du Bassin de Paris 47: 7-35.

ARKADIEV, V.V. \& BOGDANOVA, T.N. 1997. Atlas Melovoj fayny jugo-ehapadnogo kryma [In Russian]. In: Sank-Petersburgij instityt 357c, 358 pp., St Petersburg.

ARKADIEV, V.V. \& ATABEKIAN, A.A, BARABOSHKIN, E.J. \& BOGDANOVA, T.N. 2000. Stratigraphy and ammonites of the Cretaceous deposits of south-west Crimea. Palaeontographica 225:85-128.

AVRAM, E., DRAGANESCU, A., SZASZ, L. \& NEAGU, T. 1988. Stratigraphy of the outcropping Cretaceous deposits in southern Dobrogea (SE Romania). Mémoirii Institut si Géologie et de Géophysica 33: 5-43.

BENAVIDES-CÁCERES, V.E. 1956. Cretaceous system in northern Peru. Bulletin of the American Museum of Natural History 108: 353-494.

BÖSE, E. 1928. Cretaceous ammonites from Texas and northern Mexico. University of Texas Bulletin 2748: 143-357 (misdated 1927).

BOULE, M., LEMOINE, P. \& THÉVENIN, A. 1906-1907. Paléontologie de Madagascar III Céphalopodes crétacés des environs de Diego-Suarez. Annales de Paléontologie 1: 173-192 (1-20); 2: 1-56 (21-76).

BUSNARDO, R. 1966. In: BUSNARDO, R., ENAY, R. LATREILLE, G. \& ROUQUET, P. Le Crétacé moyen détritique à céphalopodes près de Poncin (Jura méridional). Travaux $d u$ Laboratoire de Géologie, Lyon, N.S. 13: 205-228.
CHOFFAT, P. 1903. Contributions à la connaissance géologique des colonies portugaises d'Afrique. I, le Crétacique de Conducia. Commission du Service Géologique de Portugal: $32 \mathrm{pp}$.

COLLIGNON, M., 1929. Paléontologie de Madagascar. XV. Les cephalopodes du Cénomanien pyriteux de Diego-Suarez. Annales de Paléontologie 18: 137-160.

COLLIGNON, M. 1931. Paléontologie de Madagascar, XVI. La faune du Cénomanien à fossiles pyriteux du nord de Madagascar. Annales de Paléontologie 20: 43-104 (1-64).

COLLIGNON, M. 1933. Fossiles cénomaniens d'Antsatramahavelona (Province d'Analalava, Madagascar). Annales géologiques du Service des Mines Gouvernement Général de Madagascar et dépendances 3: 53-79.

COLLIGNON, M. 1964. Atlas des fossiles caractéristiques de Madagascar (Ammonites), XI Cénomanien. xi + 152 pp. Tananarive: Service Géologique.

COOPER, M.R. 2012. New names for late Jurassic-Cretaceous ammonites. Neues Jahrbuch für Geologie und Paläontologie, Abhandlungen 266: $185-186$

COQUAND, H. 1862. Géologie et paléontologie de la région de la Province de Constantine. Mémoires de la Société d'Émulation de la Provence 2: 1-341.

CRICK, G.C. 1907. Cretaceous fossils of Natal. In ANDERSON, W. Third and final report of the Geological Survey of Natal and Zululand: 161-250 London: West, Newman \&Co.

DELAMETTE, M. \& KENNEDY, W.J. 1991. Cenomanian ammonites from the condensed deposits of the Helvetic Domain. Journal of Paleontology 65: 435-465.

DIXON, F. 1850. The Geology and Fossils of the Tertiary and Cretaceous Formations of Sussex. 1st Edn., xxxii +423 pp. Brighton: W.J. Smith.

GALE, A.S., HANCOCK, J.M. \& KENNEDY, W.J. 1999. Biostratigraphical and sequence correlation of the Cenomanian successions in Mangyshlak (Kazakhstan), Crimea (Ukraine) and southern England. Bulletin de l'Institut Royal des Sciences Naturelles de Belgique, Sciences de la Terre 68: 67-82.

GALE, A.S., KENNEDY, W.J., BURNETT, J.A., CARON, M. \& KIDD, B.E. 1996. The Late Albian to Early Cenomanian succession at Mont Risou near Rosans (Drôme, SA France): an integrated study (ammonites, inoceramids, planktonic foraminifera, nannofossils, oxygen and carbon isotopes). Cretaceous Research 17: 515-606.

GALE, A.S., BOWN, P., CARON, M., CRAMPTON, J., CROWHURST, S. J., KENNEDY, W. J., PETRIZZO, M.R. \& WRAY, D.S. 2011. The uppermost Middle and Upper Albian succession at the Col de Palluel, Hautes-Alpes, France: an integrated study (ammonites, inoceramid bivalves, planktonic foraminifera, nannofossils, geochemistry, stable oxygen and carbon isotopes, cyclostratigraphy). Cretaceous Research 37: 59-130.

GAUTHIER, H. 2006. Révision Critique de la Paléontologie Française d'Alcide d'Orbigny, 6, Céphalopodes Crétacés: 1-292 +1-662. Leiden: Backhuys.

GROSSOUVRE, A. de 1894. Recherches sur la craie supérieure, 2, Paléontologie. Les ammonites de la craie supérieure. Mémoires du Service de la Carte géologique détaillé de la France: 1-264 (mislabelled 1893).

HAAS, O. 1942. Some Upper Cretaceous ammonites from Angola. American Museum Novitates 1182: 24 pp.

HANCOCK, J.M., KENNEDY, W.J. \& COBBAN, W.A. 1993 A correlation of the upper Albian to basal Coniacian sequences of north west Europe, Texas and the United States Western Interior. Geological Association of Canada Special Paper 39: 453-476.

HOEPEN, E.C.N. van. 1942. Die gekielde ammonite van die Suid-Afrikaanse Gault. II. Drepanoceratidae, Pervinquieridae, Arestoceratidae, Cainoceratidae. Paleontologiese Navorsing van die Nasionale Museum Bloemfontein 1: 91-156.

HOWARTH, M.K. 1985. Cenomanian and Turonian ammonites from the Novo Redondo area, Angola. Bulletin of the British Museum (Natural History) Geology 39: 73-105. 
HYATT, A. 1889. Genesis of the Arietidae. Smithsonian Contributions to Knowledge. 673: xi +239 pp.

HYATT, A.1903. Pseudoceratites of the Cretaceous. United States Geological Survey Monograph 44: 1-351.

HAYAKAWA, H. \& TAKAHASHI, T. 2000. Sharpeiceras (Cretaceous acanthoceratid) from Nakagawa, Hokkaido. Bulletin of the Nakagawa Museum of Natural History 3: 7-14.

HISS, M. 1982. Ammonitien des Cenomans vom Südrand der Westfälischen Kreide zwischen Unna und Möhnesee. Paläontologische Zeitschrift 56: 177-208.

IMMEL, H. \& SEYED-EMAMI, K. 1985. Die Kreideammoniten des Glaukonitkalkes (0. Alb-0.Cenoman) des Kolah - Qazi - Gebirges südostlich von Esfahan (Zentral Iran). Zitteliana 12: 87-137.

JUIGNET, P. \& KENNEDY, W.J. 1976, Faunes d'ammonites et biostratigraphie compareé du Cénomanien du nord-ouest de la France (Normandie) et du sud d'Angleterre. Bulletin trimestriel de la Société géologique de Normandie et des Amis du Muséum du Havre 63: 1-193.

KELLUM, L.B. \& MINTZ, L.W. 1962. Cenomanian ammonites from the Sierra de Tlahualilo, Coahuila, Mexico. Contributions from the Museum of Paleontology of the University of Michigan 13: $267-287$.

KANIE, Y., HIRANO, H.\& TANABE, K. 1977. Lower Cenomanian molluscs from Diégo-Suarez, northern Madagascar. Bulletin of the National Science Museum 3: 107-132.

KAPLAN, U., KENNEDY, W. J., LEHMANN, J. \& MARCINOWSKI, R. 1998. Stratigraphie und Ammonitenfaunen des westfälischen Cenoman. Geologie und Paläontologie in Westfalen 51: 236 pp.

KAWABE, F., TAKASHIMA, R., WANI, R., NISHI, H. \& MORIYA, K. 2003. Upper Albian to Lower Cenomanian biostratigraphy in the Oyubari area, Hokkaido, Japan: towards a Cretaceous biochronology for the North Pacific. Acta Geologica Polonica 53: 81-91.

KENNEDY, W.J. 1971. Cenomanian ammonites from southern England. Special Papers in Palaeontology 8: v +133 pp.

KENNEDY, W.J. 1994. Cenomanian ammonites from Cassis, Bouches-du-Rhône, France. Palaeopelagos, Special Volume 1: 209-254.

KENNEDY, W.J. 2014. In: WALASCZYK, I., KENNEDY, W.J., DEMBICZ, K., GALE, A.S., PRASZKIER, T., RASOAAMIARAMANA, A.H. \& RANDRIANALY, H. 2014. Ammonite and inoceramid biostratigraphy and biogeography of the Cenomanian through basal Middle Campanian (Upper Cretaceous) of the Morondava Basin, Western Madagascar. Journal of African Earth Sciences 89: 79-132.

KENNEDY, W. J. 2014. Sharpeiceras australe sp. nov, replacement name for Sharpeiceras falloti Kennedy, 2013, non Collignon, 1931. Acta Geologica Polonica 64: 109-111.

KENNEDY, W. J., AMÉDRO, F., ROBASZYNSKI, F. \& JAGT, J. W. M. 2011. Ammonite faunas from condensed CenomanianTuronian sections ('Tourtias') in southern Belgium and northern France. In: JAGT, J.W.M., SCHINS, W.J.H. \& JAGTYAZYKOVA, E.A. (eds). Netherlands Journal of Geosciences 90: 209-223.

KENNEDY, W. J., COBBAN, W. J., HANCOCK, J. M. \& GALE, A.S. 2005. Upper Albian and Cenomanian ammonites from the Main Street Limestone, Grayson Marl and Del Rio Clay in northeast Texas. Cretaceous Research 26: 349-428.

KENNEDY, W.J., JUIGNET, P. \& WRIGHT, C.W. 1986. A revision of the ammonite fauna of the type Cenomanian. 3. Mantelliceratinae. Cretaceous Research 7:19-62.

KENNEDY, W.J. \& KLINGER, H.C. 1975. Cretaceous faunas from Zululand and Natal, South Africa. Introduction, Stratigraphy. Bulletin of the British Museum (Natural History) Geology 25: 263-315.

KENNEDY, W.J., WALASZCZYK, I., GALE, A.S., DEMBICZ, K. \& PRASZKIER, T., 2013. Lower and Middle Cenomanian ammonites from the Morondava Basin, Madagascar. Acta Geologica Polonica 63: 625-655.

KORN, D., EBBIGHAUSEN, V., BOCKWINKEL, J. \& KLUG, C.
2003. The A-mode ontogeny in prolecanitid ammonites. Palaeontology 46: 1123-1132.

KOSSMAT, F. 1895-1898. Untersuchungen über die Südindische Kreideformation. Beiträge zur Paläontologie ÖsterreichUngarns und des Orients 9 (1895): 97-203 (1-107); 11 (1897): 1-46 (108-153); 11(1898): 89-152 (154-217).

KULLMANN, J. \& WIEDMANN, J. 1970. Significance of sutures in phylogeny of Ammonoidea. University of Kansas, Paleontological Contributions 42: 1-32.

LEHMANN, J. 1998. Systematic palaeontology of the ammonites of the Cenomanian-Lower Turonian (Upper Cretaceous) of northern Westphalia, North Germany. Tübingen Geowissenschaftliche Arbeiten 37: 1-58.

MANCINI, E.A. 1979. Late Albian and early Cenomanian ammonite biostratigraphy in North-Central Texas. Journal of Paleontology 53: 1013-1022.

MANCINI, E.A. 1982. Early Cenomanian Cephalopods from the Grayson Formation of North-central Texas. Cretaceous Research 3: 241-259.

MANTELL, G.A. 1822. The fossils of the South Downs; or illustrations of the geology of Sussex. xvi $+327 \mathrm{pp}$. London: Lupton Relfe.

MARCINOWSKI, R., WALASZCZYK, I. \& OLSZEWSKANEJBERT, D. 1996. Stratigraphy and regional development of the mid-Cretaceous (Upper Albian through Coniacian), of the Mangyshlak Mountains, Western Kazakhstan. Acta Geologica Polonica 46: 1-60.

MARCINOWSKI, R. \& WIEDMANN, J. 1990. The Albian ammonites of Poland. Palaeontologica Polonica 50: 94 pp.

MATSUMOTO, T, 1959. Upper Cretaceous ammonites of California. II. Memoirs of the Faculty of Science, Kyushu University, Series D, Geology. Special Volume 1: 1-172.

MATSUMOTO, T., HAYAKAWA, H. \& TOSHIMITSU, S. 1999. An ammonite species of Sharpeiceras from Madagascar. Bulletin of the Mikasa City Museum 3: 17-21.

MATSUMOTO, T.\& KAWASHITA, Y. 1998. Two ammonite species of the genus Sharpeiceras from the Cretaceous of Hokkaido. Paleontological Research 2: 89-95.

MATSUMOTO, T., MURAMOTO, T. \& TAKAHASHI, T. 1969. Selected acanthoceratids from Hokkaido. Memoirs of the Faculty of Science, Kyushu University, Series D, Geology 19: 251-296.

MATSUMOTO, T. \& SARKAR, S.S. 1966. Utaturiceras vicinale (Stoliczka) from Southern India, pp. 297-309, In: MATSUMOTO, T., SASTRY, M.V.A. \& SARKAR, S.S. 1966. Notes on some Cretaceous ammonites from southern India. Memoirs of the Faculty of Science, Kyushu University, Series D, Geology 17: 295-309.

MATSUMOTO, T., NISHIDA, T. \& TOSHIMITSU, S. 2003. Early Cenomanian (Cretaceous) ammonoids Utaturiceras and Graysonites from Hokkaido, North Japan. Bulletin of the Geological Society of Japan 54, 131-159

MATSUMOTO, T., NISHIDA, T. \& TOSHIMITSU, S. 2004. The early Cenomanian (Cretaceous) ammonite fauna from the Soeushinai area of Hokkaido, North Japan. (Studies of the Cretaceous ammonites from Hokkaido and Sakhalin XCVII). Bulletin of the Geological Survey of Japan 55: 67-92.

MATSUMOTO, T. \& TOSHIMITSU, S. 1991. A find of a Cenomanian ammonite from Tomiuchi, Hobetsu, district, Hokkaido. Bulletin of the Hobetsu Museum 7, 1-8.

MATSUMOTO, T. \& TOSHIMITSU, S. 1998. On some species of Sharpeiceras (Ammonoidea) from the Cretaceous of Hokkaido. Bulletin of the Geological Survey of Japan 49: 621-631.

MATSUMOTO, T. \& TOSHIMITSU, S. 2005. Additional notes on some species of Mantelliceras (Ammonoidea) from Central Hokkaido, North Japan. Bulletin of the Geological Survey of Japan 56: 31-36.

MEISTER, C., BUTA, A., DAVID, B. \& TAVARES, T. 2011. Les ammonites de la limite Albien-Cénomanien dans la region de Sumbe (Bassin de la Kwanza, Angola). Revue de Paléobiologie 30: 685-781.

MOSAVINA, A. \& WILMSEN M. 2011. Cenomanian Acanthoceratoidea (Cretaceous Ammonoidea) from the Koppeh Dagh, NE 
Iran: taxonomy and stratigraphic implications. Acta Geologica Polonica 61: 175-192.

NISHIDA, T., MATSUMOTO, T., YOKOI, K., KAWASHITA, Y., KYUMA, Y., EGASHIRA, N., AIZAWA, J., MAIYA, S., IKUJI, Y. \& YAO, A. 1996. Biostratigraphy of the Cretaceous Middle Yezo Group in the Soeushinai area of Hokkaido-with special reference to the transitional part from the Lower to Upper Cretaceous. Journal of the Faculty of Education, Saga University 44: 65-149 [In Japanese with English abstract].

ORBIGNY, A. d'. 1840-1842. Paléontologie française: Terrains crétacés. 1. Céphalopodes. 1-120 (1840); 121-430 (1841); 431-662 (1842). Paris: Masson.

ORBIGNY, A. d'. 1850. Prodrome de Paléontologie stratigraphique universelle des animaux Mollusques et rayonnés faisant suite au cours élémentaire de Paléontologie et de Géologie stratigraphiques. 2, $427 \mathrm{pp}$. Paris: Masson.

PERVINQUIÈRE, L. 1907. Études de paléontologie tunisienne. 1. Céphalopodes des terrains secondaires. Carte Géologique de la Tunisie, $\mathrm{v}+438 \mathrm{pp}$.

PICTET, F. J. \& CAMPICHE, G. 1858-1864. Description des fossiles du terrain crétacé des environs de Saint-Croix part 2 (1). Description des fossiles. Matériaux pour la Paléontologie Suisse (2) part 1, 1-380; part 2, 1-752.

REBOULET, S., GIRAUD, F., COLOMBIÉ, C. \& CARPENTIER, A 2013. Integrated stratigraphy of the Lower and Middle Cenomanian in a Tethyan section (Blieux, southeast France) and correlations with the Boreal basins. Cretaceous Research 40: 170189.

SHARPE, D. 1853-57. Description of the fossil remains of Mollusca found in the Chalk of England. I, Cephalopoda. Palaeontographical Society Monographs. 68 pp.1-26(1853); 27-36(1855); 37-68(1857).

SOWERBY, J. 1812-1822. The Mineral Conchology of Great Britain. 1, pls. 1-9 (1812), pls. 10-44 (1813, pls. 45-78 (1814), pls. 79-102 (1815); 2, pls. 103-114 (1815), pls. 115-150 (1816), pls. 151-186 (1817), pls. 187-203 (1818); 3, pls. 204-221 (1818), pls. 222-253 (1819), pls. 254-271 (1820), pls. 272-306 (1821); 4, pls. 307-318 (1821), pls. 319-383 (1822). London: the Author.

SPATH, L.F. 1923. On the ammonite horizons of the Gault and contiguous deposits. Summary of Progress of the Geological Survey of Great Britain for 1922, 139-149.

SPATH, L.F. 1925. On Upper Albian Ammonoidea from Portuguese East Africa, with an appendix on Upper Cretaceous ammonites from Maputoland. Annals of the Transvaal Museum 11: 179-200.

SPATH, L.F. 1926a. On new ammonites from the English Chalk. Geological Magazine 63: 77-83.

SPATH, L.F. 1926b. On the zones of the Cenomanian and the uppermost Albian. Proceedings of the Geologists' Association 37: $420-432$.

STOLICZKA, F. 1863-1866. The fossil Cephalopoda of the Cretaceous rocks of southern India. Ammonitidae with revision of the
Nautilidae etc. Memoirs of the Geological Survey of India. (1), Palaeontologica Indica, 3 (1): 41-56(1863); (2-5), 57-106(1864); (6-9), 107-154(1865); (10-13), 155-216(1866).

THOMEL, G. 1972. Les Acanthoceratidae Cénomaniens des chaines subalpines méridionales. Mémoires de la Société géologique de France (N.S.) 116: 204 pp.

WALASZCZYK, I., KENNEDY, W.J., DEMBICZ, K., GALE, A.S., PRASZKIER, T., RASOAMIARAMANA, A.H. \& RANDRIANALY,H. 2014. Ammonite and inoceramid biostratigraphy and biogeography of the Cenomanian through basal Middle Campanian (Cretaceous) of the Morondava Basin, Western Madagascar. Journal of African Earth Sciences 89: 79-132.

WIEDMANN, J. \& SCHNEIDER, H.-L. 1979. Cephalopoden und Alter der Cenoman-Transgression von Mühlheim-Broich, SW-Westfalen. In: WIEDMANN, J. (ed.) Aspekte der Kreide Europas. Beiträge, IUGS (International Union of Geological Sciences) Series A, vol. 6: 645-680.

WILMSEN, M. 1997. Das Oberalb und Cenoman im nordkantabrischen Becken (Provinz Kantabrien, Nordspanien). Faziesentwicklung, bio- und Sequenzstratigraphie. In: Vol. E 23, $\mathrm{x}+167$, Berlin.

WILMSEN, M., STORM, M. FÜRSICH, F.T. \& MAJIDIFARD, M.,R. 2013. Upper Albian and Cenomanian (Cretaceous ammonites from the Debarsu Formation (Yazd Block, central Iran) Acta Geologica Polonica 63: 489-513

WILMSEN, M., WOOD, C. J. NIEBUHR, B. \& KAPLAN, U. 2009 Cenomanian-Coniacian ammonoids of the Danubian Cretaceous Group (Bavaria, southern Germany). Schriftenreihe der Deutschen Gesellschaft für Geowissenschaften 65: 111-124.

WRIGHT, C.W. 1956. Notes on Cretaceous ammonites. III Utaturiceras gen. nov. and the Metoicoceratinae. Annals and Magazine of Natural History (12) 9: 391-393.

WRIGHT, C.W. \& KENNEDY, W.J. 1984. The Ammonoidea of the Lower Chalk. Part 1. Palaeontographical Society Monographs: $1-126$.

WRIGHT, C.W. \& KENNEDY, W.J. 1987. The Ammonoidea of the Lower Chalk. Part 2. Palaeontographical Society Monographs: 127-218.

WRIGHT, C.W. \& KENNEDY, W.J. 1990. The Ammonoidea of the Lower Chalk. Part 3. Palaeontographical Society Monographs: 219-294.

WRIGHT, C.W. \& KENNEDY, W.J. 1996. The Ammonoidea of the Lower Chalk. Part 5. Palaeontographical Society Monographs: 320-403.

WRIGHT, C.W. \& WRIGHT, E.V. 1951. A survey of the fossil Cephalopoda of the Chalk of Great Britain, primarily a nomenclatorian revision of Daniel Sharpe's "Description of the fossil remains of Mollusca found in the Chalk of England: Part 1. Cephalopoda" (1853-1857). Palaeontographical Society: 1-41.

YOUNG, K. 1958. Graysonites, a Cretaceous ammonite in Texas. Journal of Paleontology 32: 171-182. 


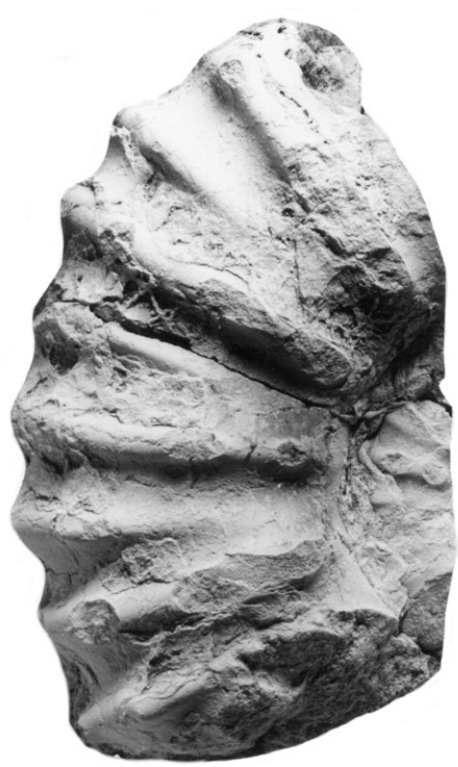

A

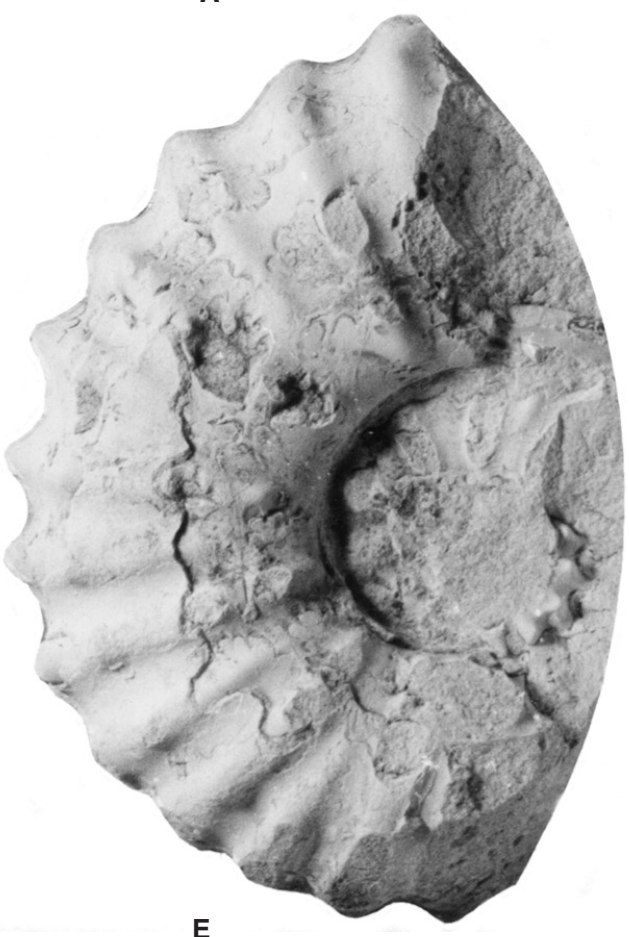

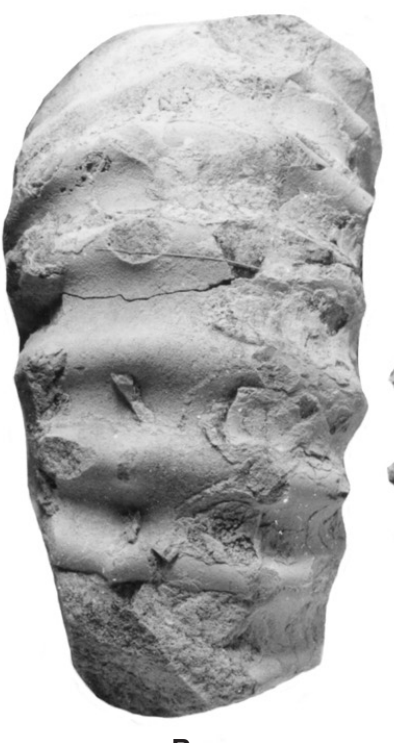

B
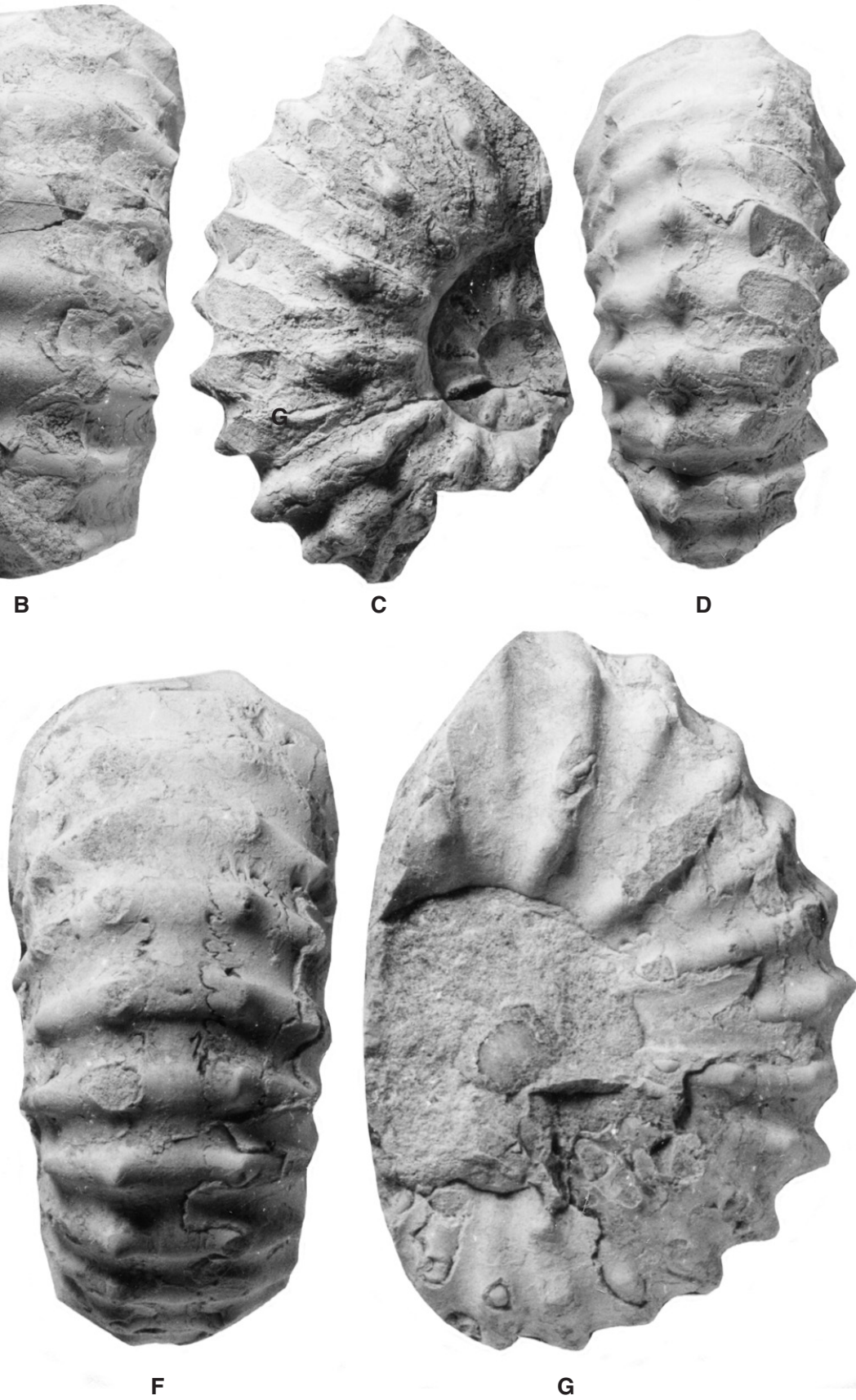

Fig. 1. A-G, Mantelliceras mantelli (J. Sowerby, 1814), from the Mzinene Formation, Cenomanian II, at locality 185. A, B, OUM KX10400; C, D, OUM KX10406; E-G, OUM KX10395. All figures are ×1. 

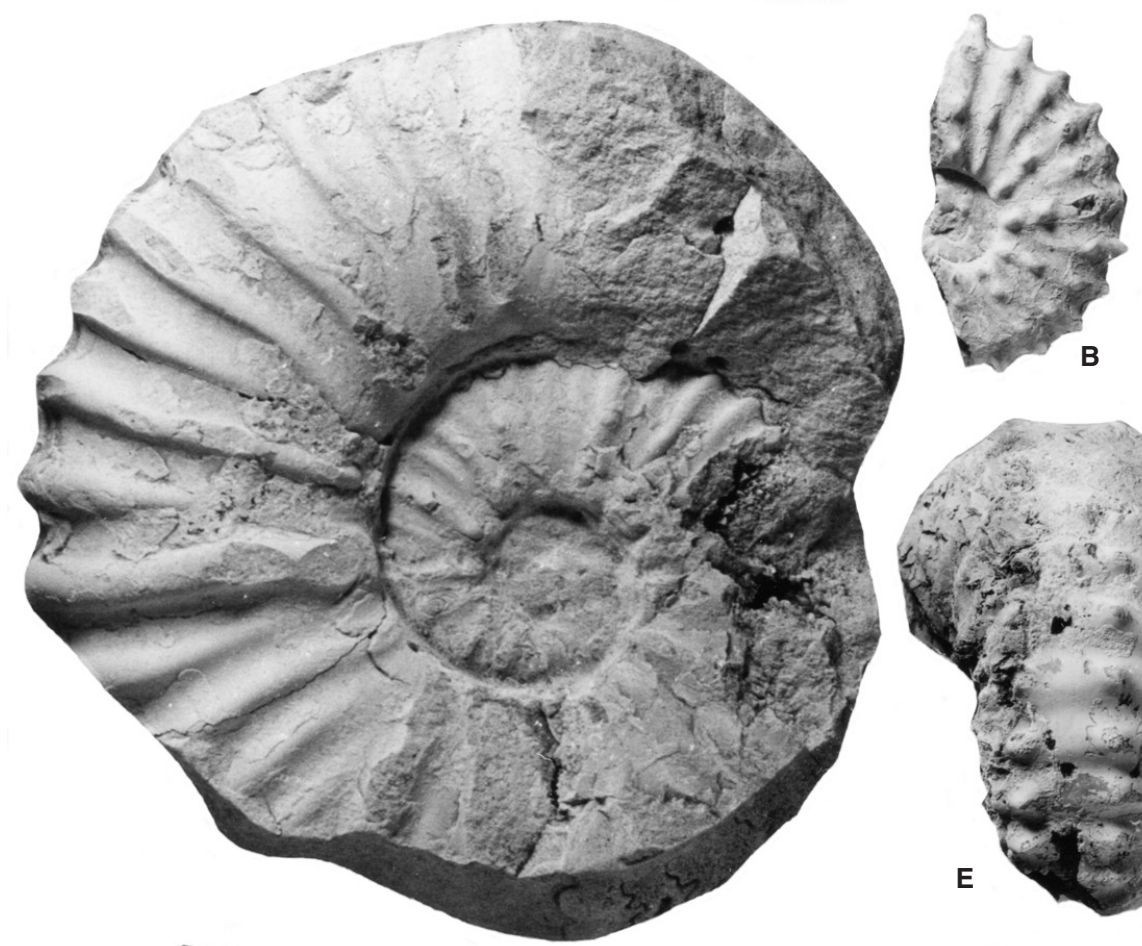

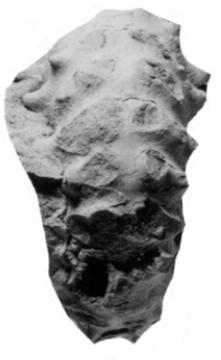

C
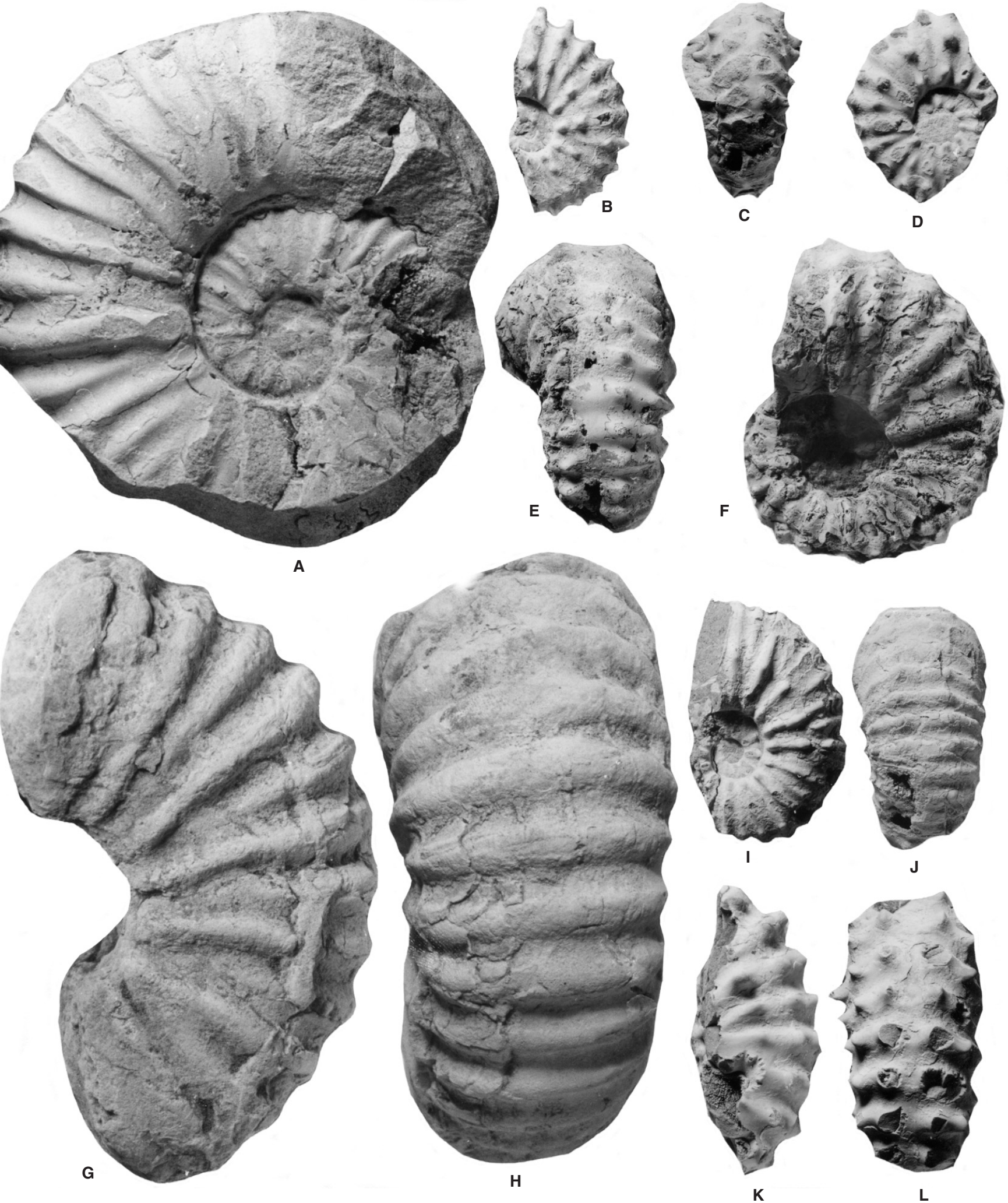

Fig. 2. A, I, J, Mantelliceras cantianum Spath, 1926a. A, OUM KX10397; I, J, SAM-PCZ22282. B, Mantelliceras picteti Hyatt, 1903, OUM KX10388a, Cenomanian II, locality 183. C-H, K, L, Mantelliceras mantelli (J. Sowerby, 1814). C, D, SAM-PCZ22281; K, L, SAM-PCZ22414, both from the Ndumu area. E, F, SAM-PCZ22410; G, H, SAM-PCZ22276, both from the Skoenberg. All specimens are from the Lower Cenomanian part of the Mzinene Formation. All figures are $\times 1$. 


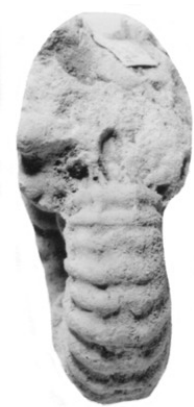

A

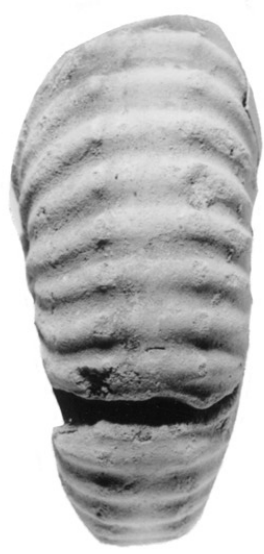

H

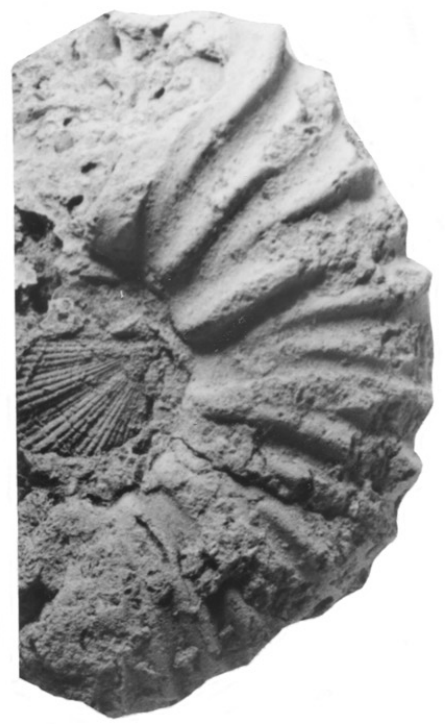

L

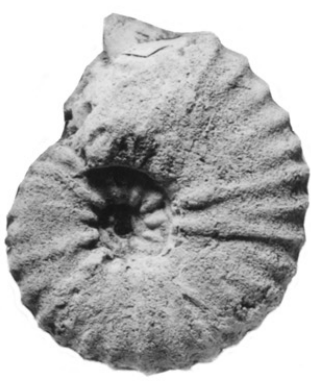

B

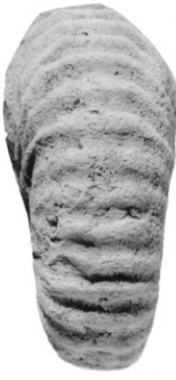

C

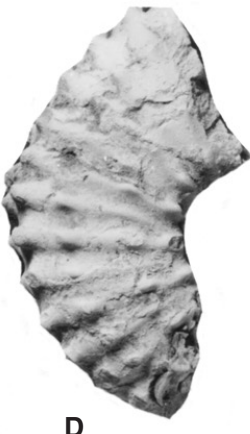

D

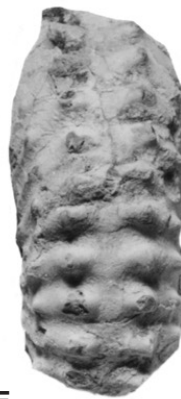

E

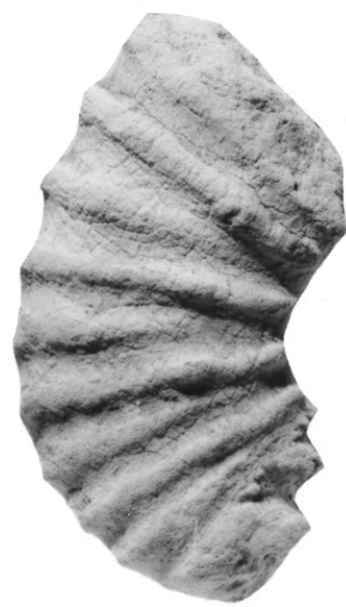

J

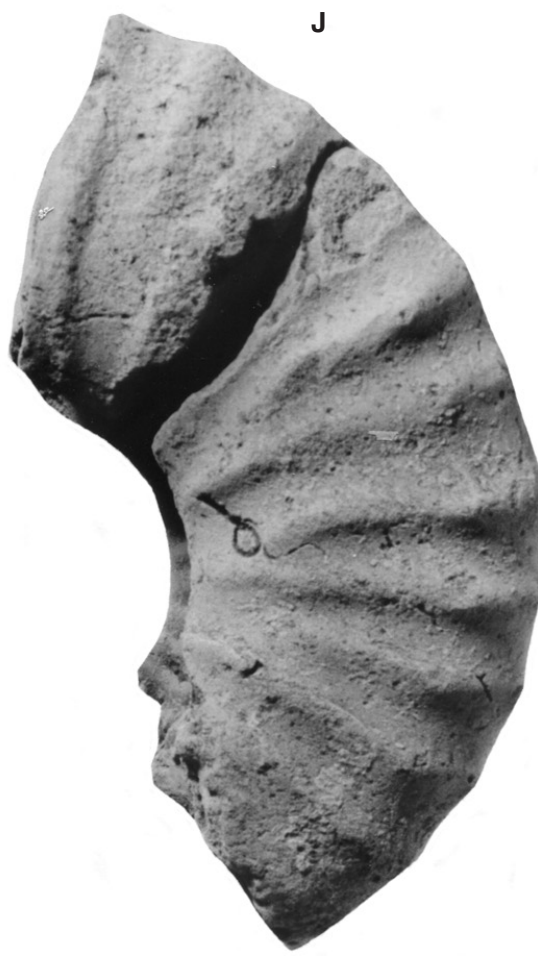

N
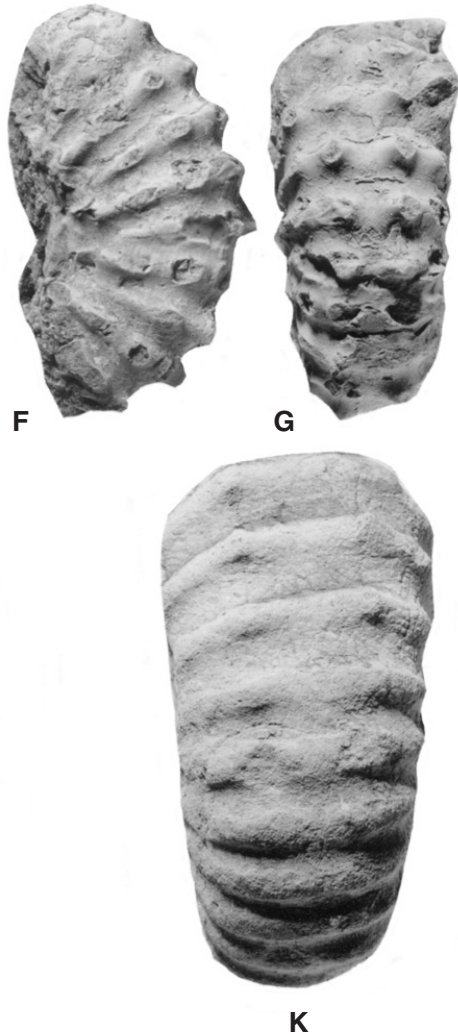

K

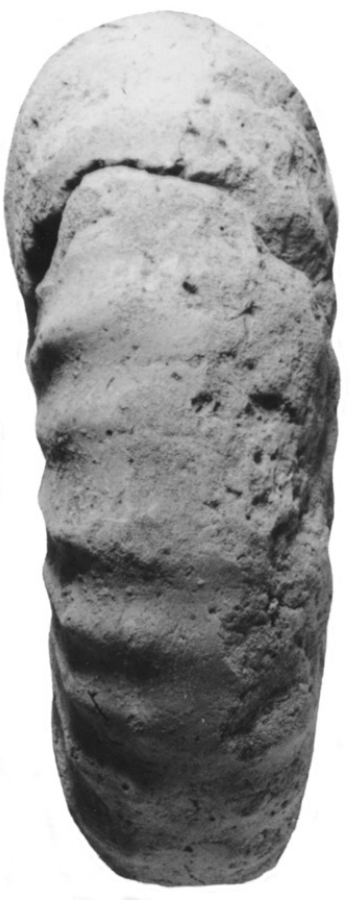

0

Fig. 3. A-C, L, M, Mantelliceras dixoni Spath, 1926b. A-C, OUM KX4671, from locality 62; L, M, OUM KX14454, from bed 14 at locality 61 , Cenomanian II. D-K, N, O, Mantelliceras mantelli (J. Sowerby, 1814). D, E, SAM-PCZ22280; F, G, SAM-PCZ22277, both from the Ndumu area. H, I, OUM KX11976, from bed 7 at locality 61, Cenomanian II; J, K, OUM KX4670, from locality 62; N, O, OUM KX2021, from bed 10 at locality 61 , Cenomanian II. All specimens are from the Lower Cenomanian part of the Mzinene Formation. All figures are $\times 1$. 


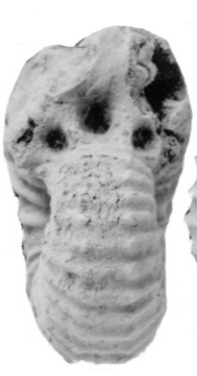

A

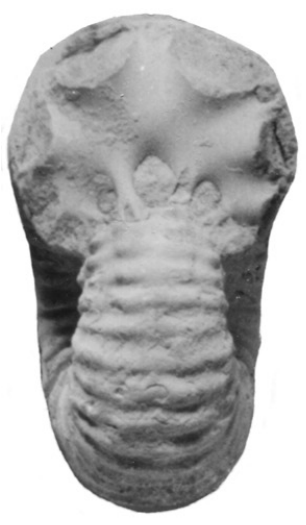

H

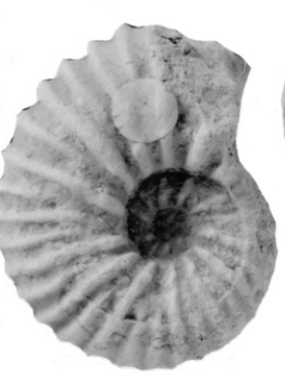

B

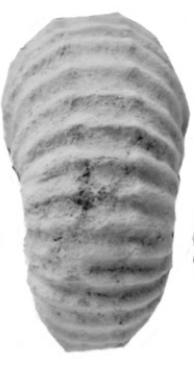

C

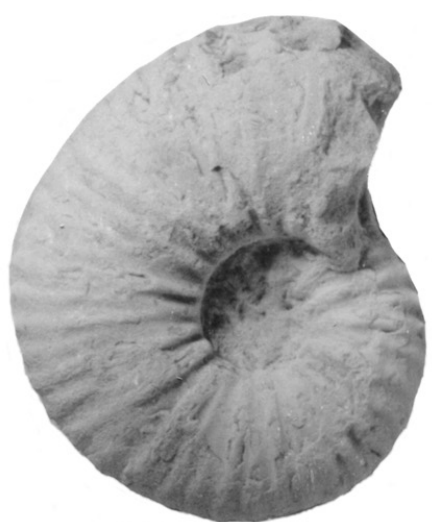

I

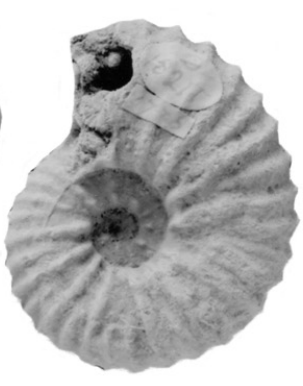

D

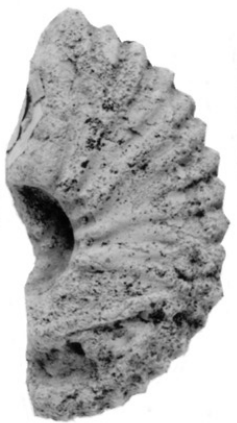

E

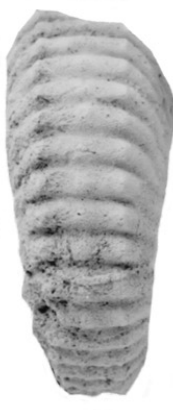

$\mathbf{F}$

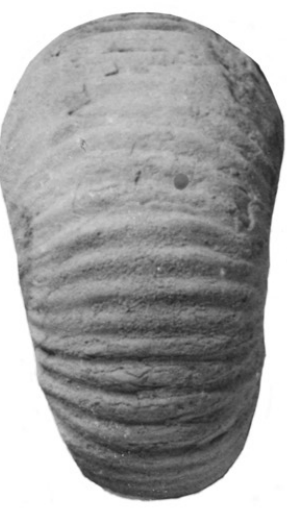

J

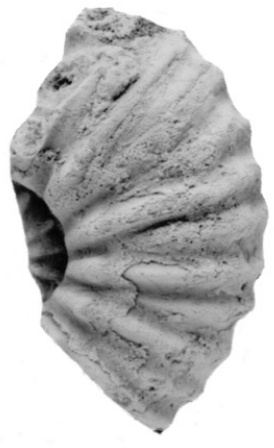

K

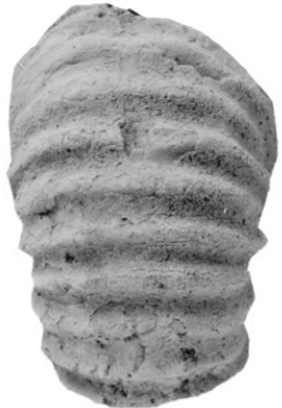

G

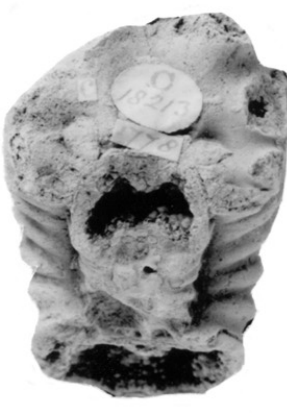

$\mathbf{L}$

Fig. 4. A-D, G-L, Mantelliceras nitidum (Crick, 1907). A-D, the holotype, BMNH C18211; G, K, L, paratype, BMNH C18312; H-J, SAM-PCZ13470. E, F, Calycoceras (Newboldiceras) sp. BMNH C18212, a paratype of Mantelliceras nitidum. The originals of A-G, K, L, are from the 'deposit at the north end of False Bay' of Crick (1907), that is to say the Skoenberg, as is the original of figs $\mathrm{H}-\mathrm{J}$, and all are inferred to be from the Lower Cenomanian part of the Mzinene Formation. 


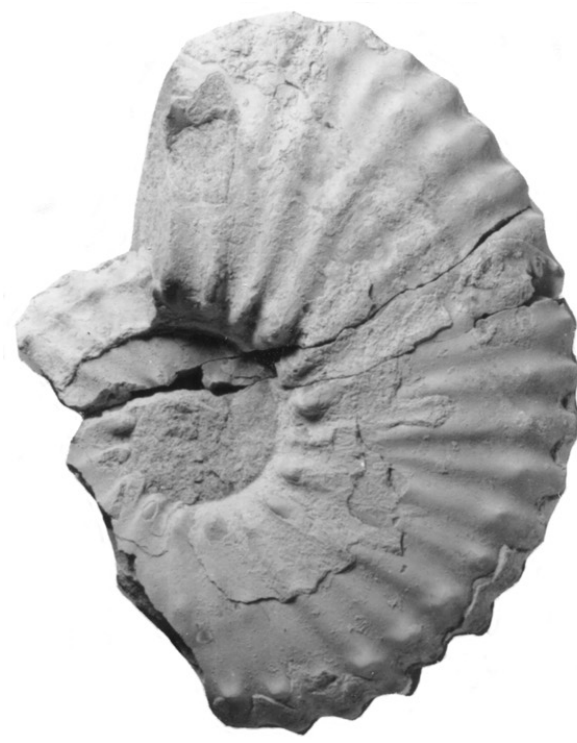

A

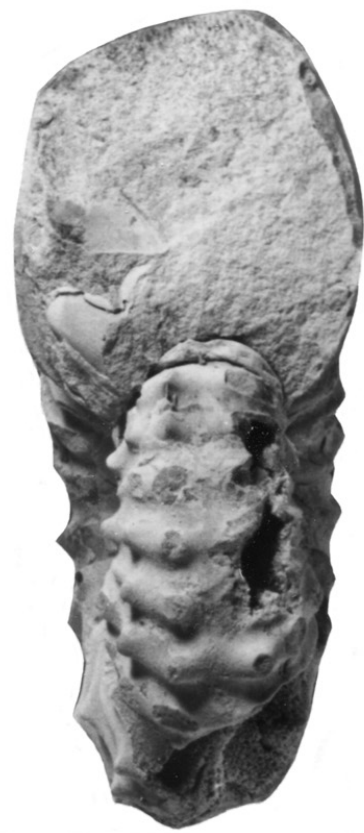

E

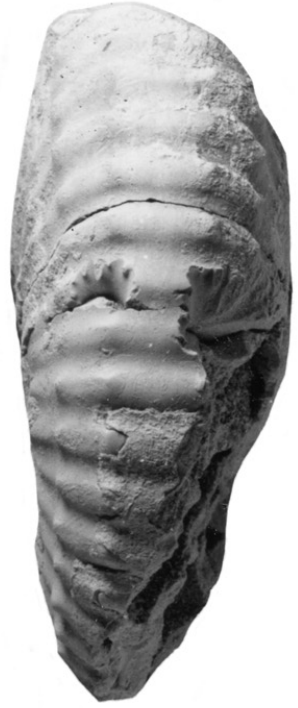

B
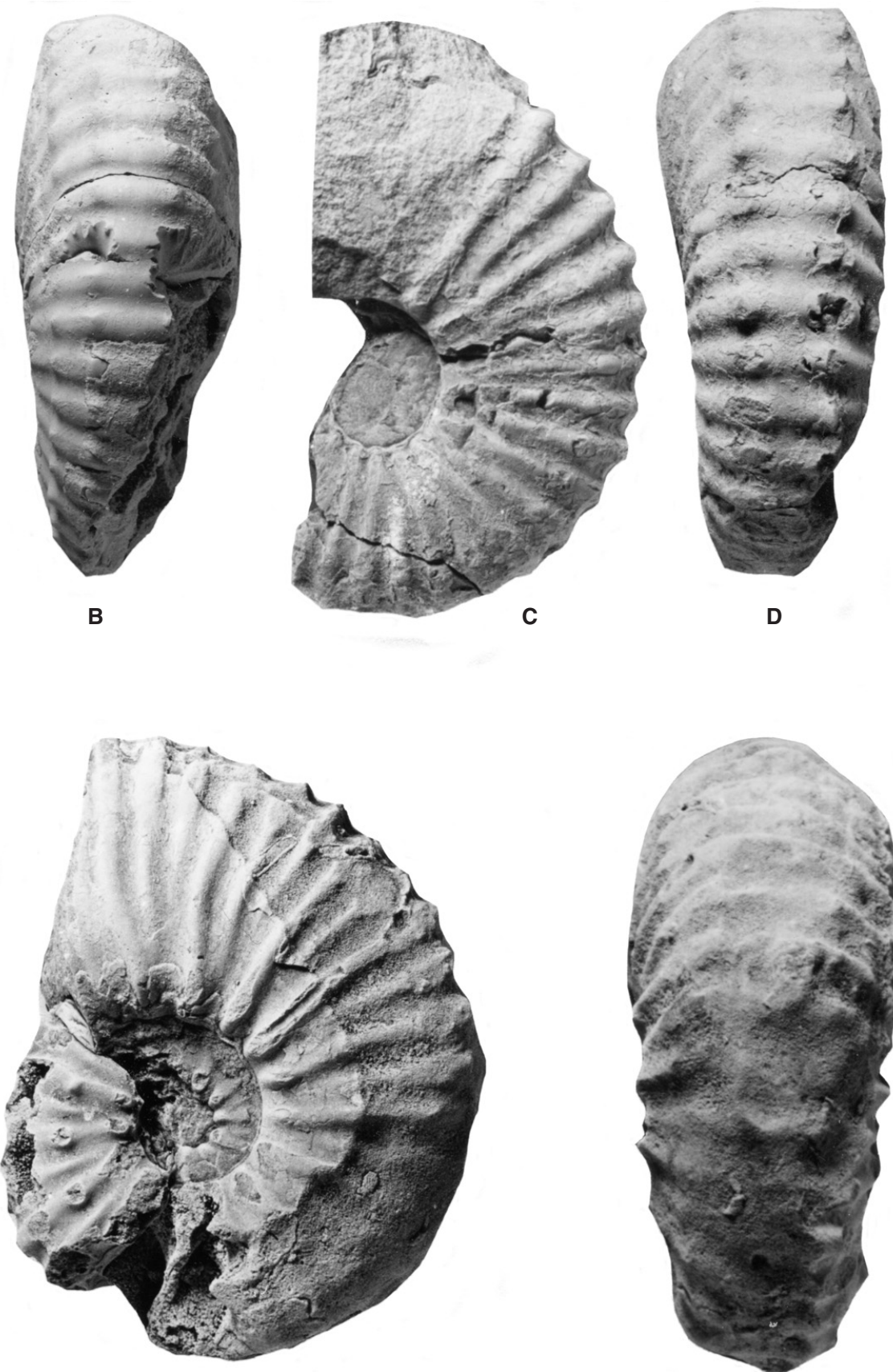

$\mathbf{F}$

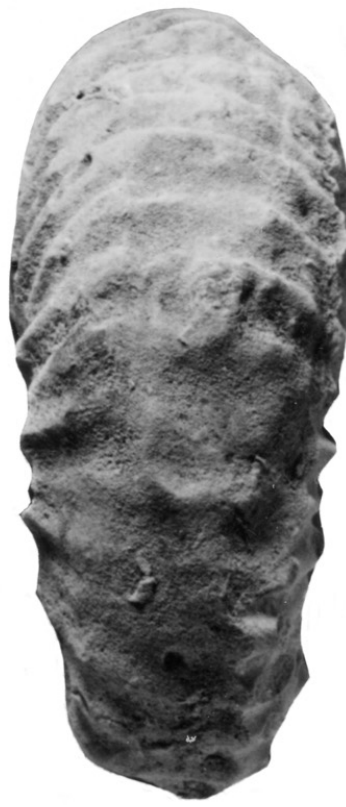

G

Fig. 5. A, B, Sharpeiceras sp. A. OUM KX10304 from bed 3 at locality 181, Cenomanian I. C, D, Mantelliceras couloni (d'Orbigny, 1850). SAM-PCZ22417, from the Ndumu area. E-G, Mantelliceras lateretuberculatum Collignon, 1964, SAM-PCZ22416, from the Ndumu area. All specimens are from the Lower Cenomanian part of the Mzinene Formation. All figures are $\times 1$. 

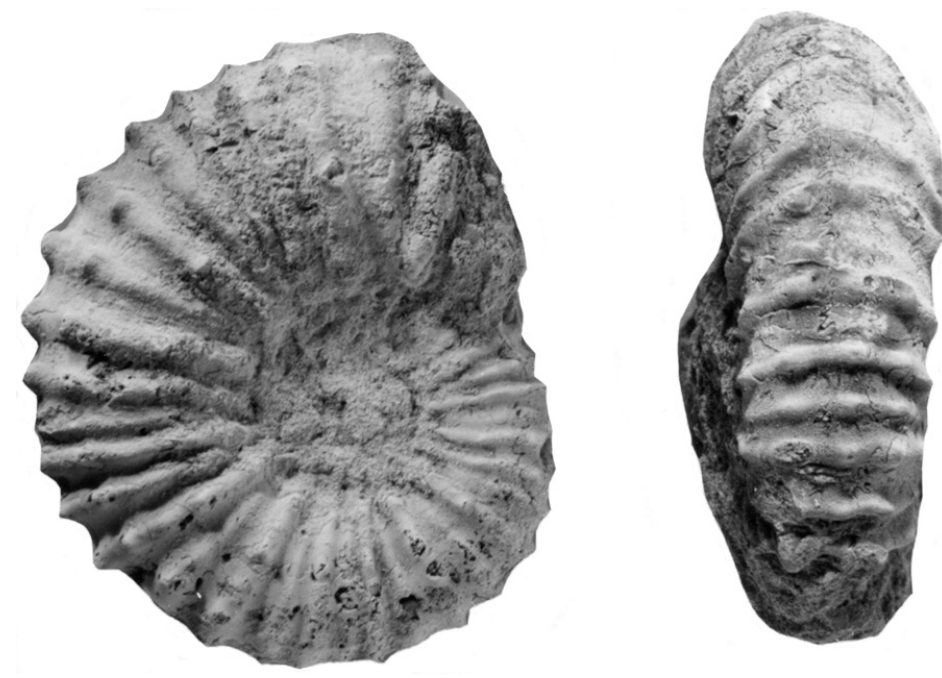

Fig. 6. The holotype of Mantelliceras antanimangaense Collignon, 1964 (p. 83, pl. 346, fig. 1539), from the Lower Cenomanian of Antanimanga (Mandabe), Madagascar. The original is housed in the collections of the Universite de Bourgogne, Dijon. Figures are $\times 1$. 


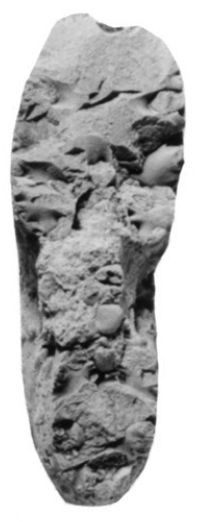

A

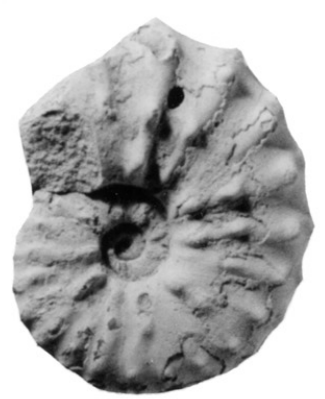

G

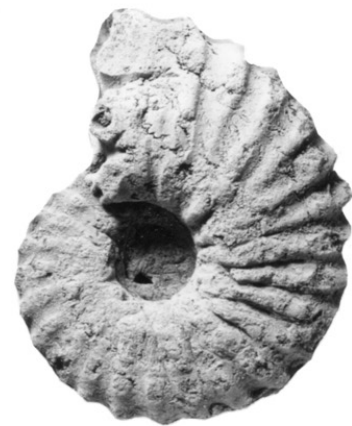

M

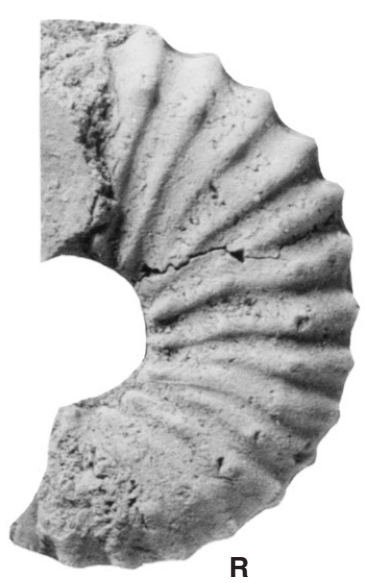

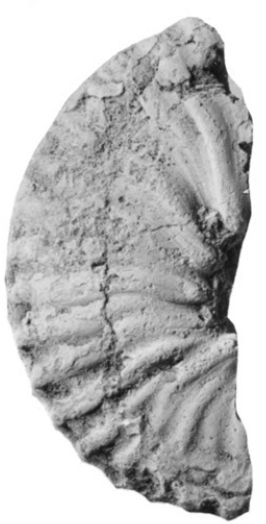

B

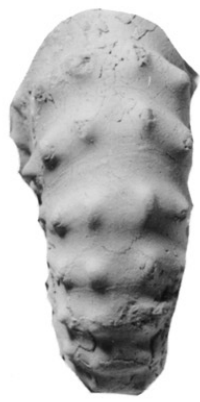

H

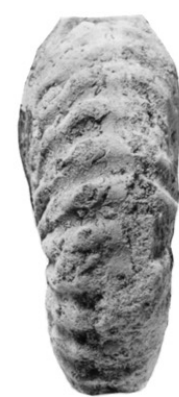

$\mathbf{N}$

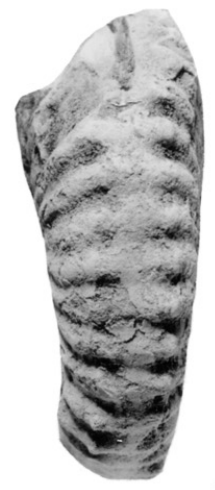

C

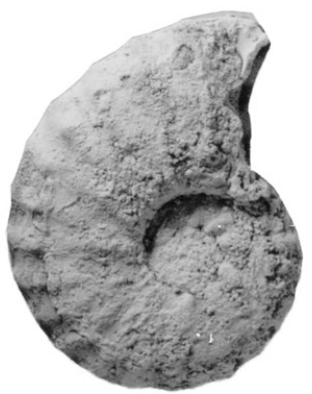

I

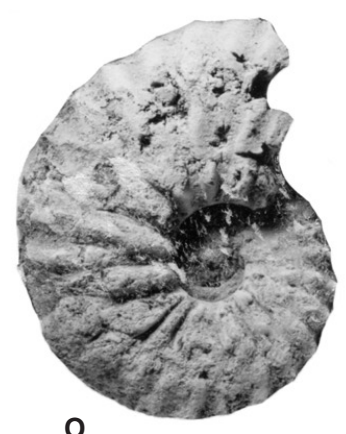

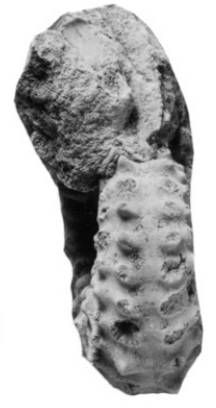

E

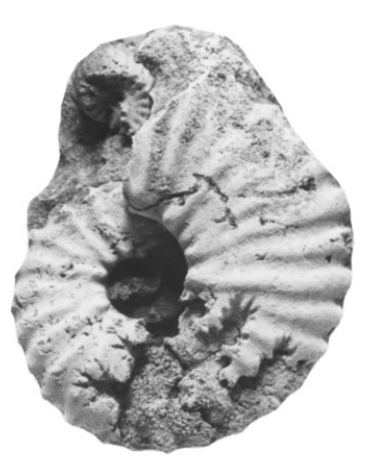

K

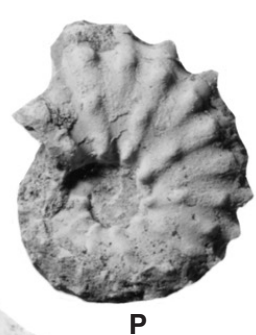

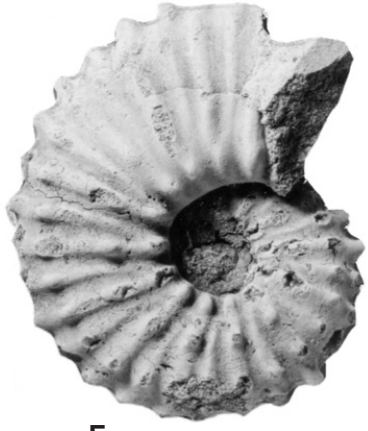

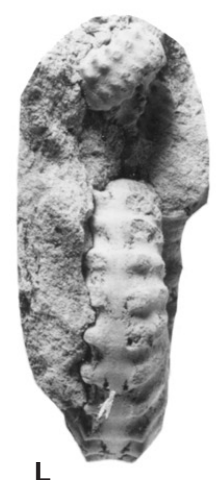

L
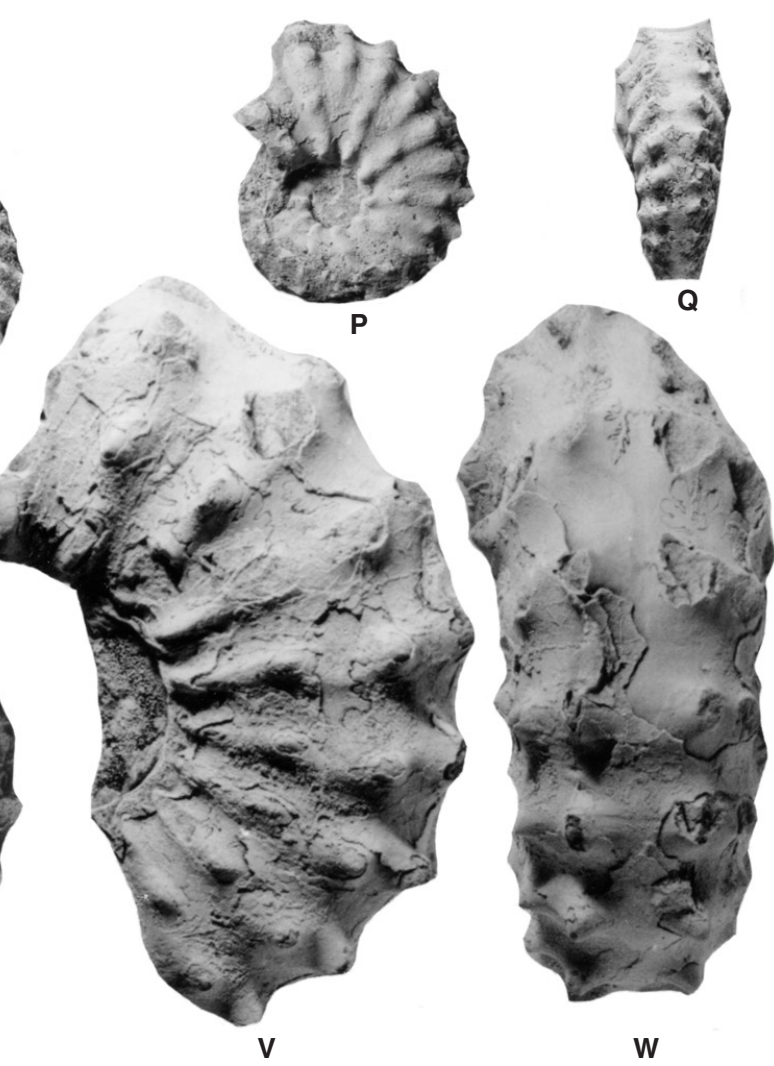

Fig. 7. A-D, Utaturiceras vicinale (Stoliczka, 1864). A-C, SAM-PCZ22412, from the Skoenberg; D, SAM-PCZ22419, from locality 183, Cenomanian II. E, F, M-O, R-T, Mantelliceras picteti Hyatt, 1903. E, F, OUM KX11521, from bed 3 at locality 61, Cenomanian I. M-O, OUM KX14567, R-T, OUM KX14569 both from Cenomanian II, locality 61. G-J, P, Q, U, V, W, Sharpeiceras florencae Spath, 1925. G, H, SAM-PCZ21295, from the Skoenberg. I, J, OUM KX10281; V, W, OUM KX10278, from bed 3 at locality 161, Cenomanian I. P, Q, U, SAM-PCZ22411, from the Skoenberg. K, L, Mantelliceras saxbii (Sharpe, 1857). SAM-PCZ22418, from the Skoenberg, locality 61, Cenomanian II. All specimens are from the Lower Cenomanian part of the Mzinene Formation. Figures A-Q, T, S, V, W, are $\times 1 ; R$ and U are $\times 2$. 


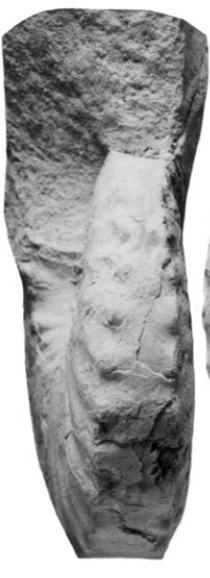

A

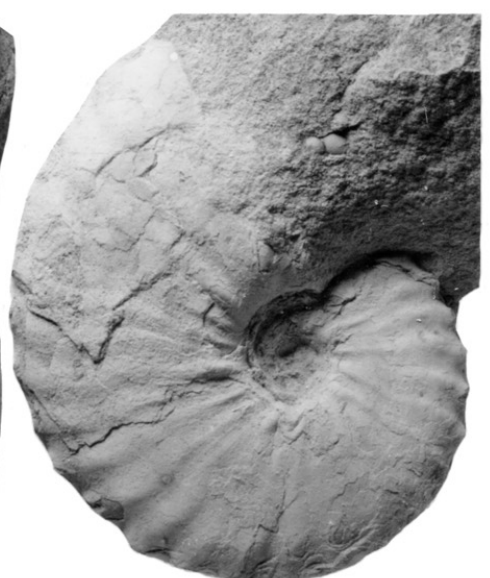

B

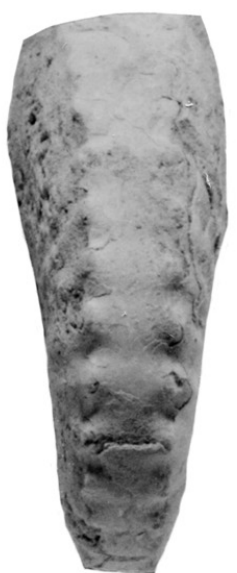

C

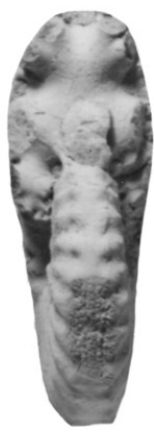

D

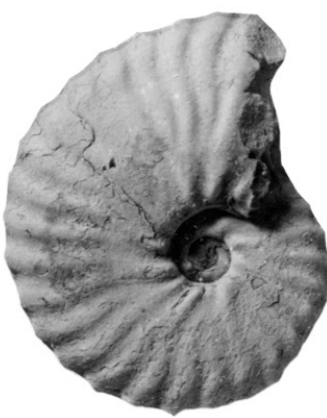

E

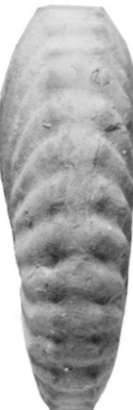

$\mathbf{F}$

Fig. 8. A-F, Utaturiceras vicinale (Stoliczka, 1864). A-C, OUM KX10303, from bed 3 at locality 181, Cenomanian I. D-F, OUM KX10404, from locality 185 , Cenomanian II. Both specimens are from the Cenomanian part of Mzinene Formation in the Ndumu area. All figures are $\times 1$. 


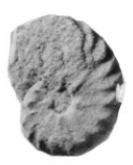

A

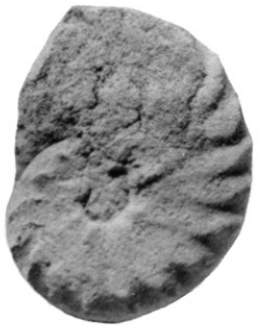

B

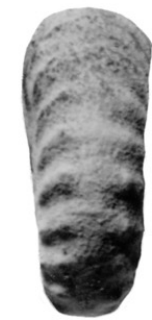

C

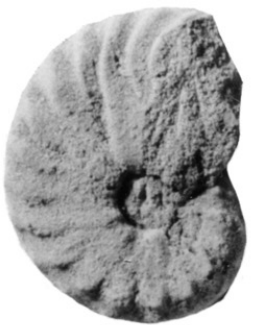

D

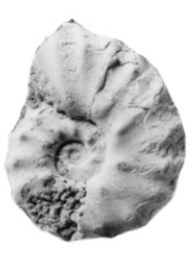

E

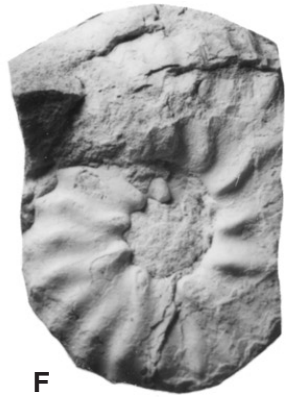

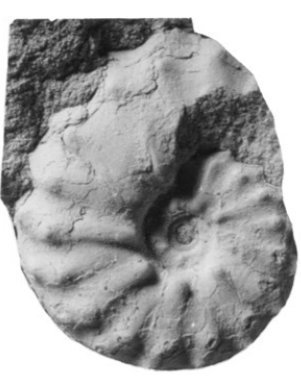

G

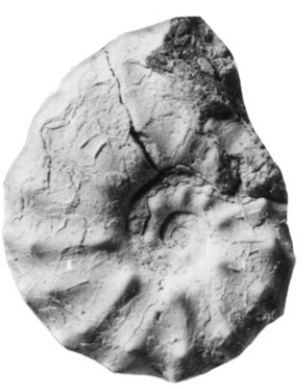

M

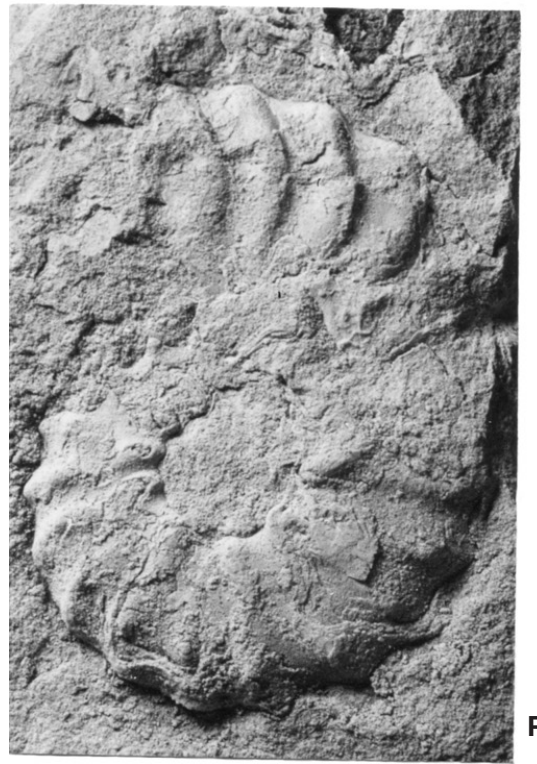

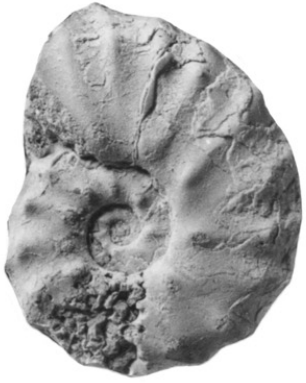

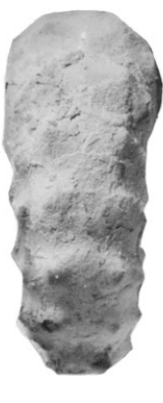

$\mathbf{J}$

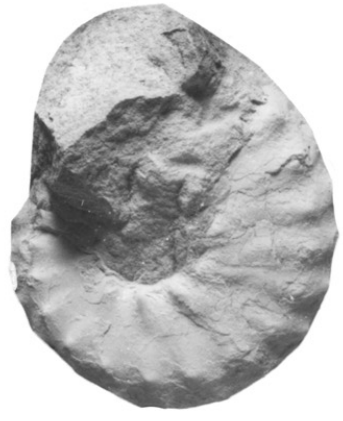

K

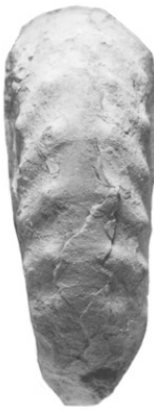

L

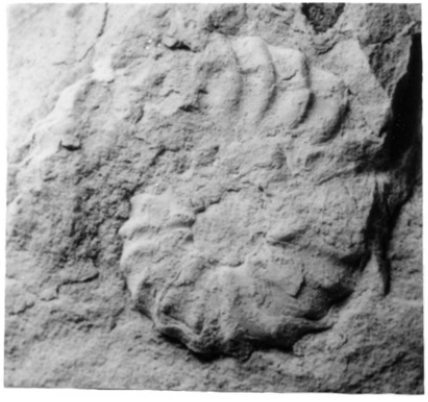

$\mathbf{N}$

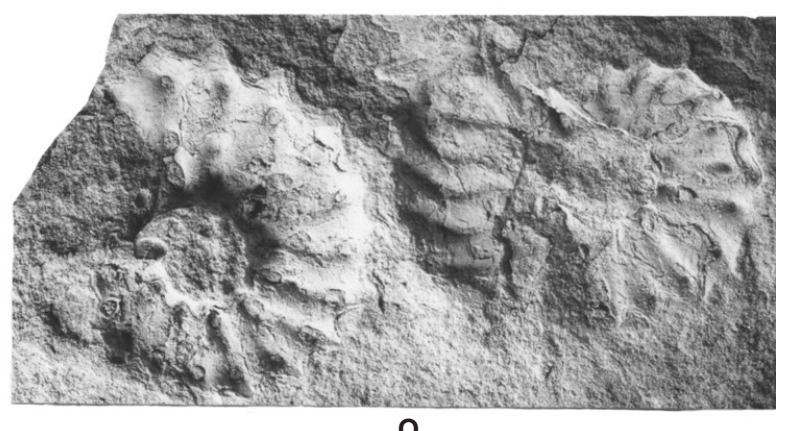

$\mathbf{0}$

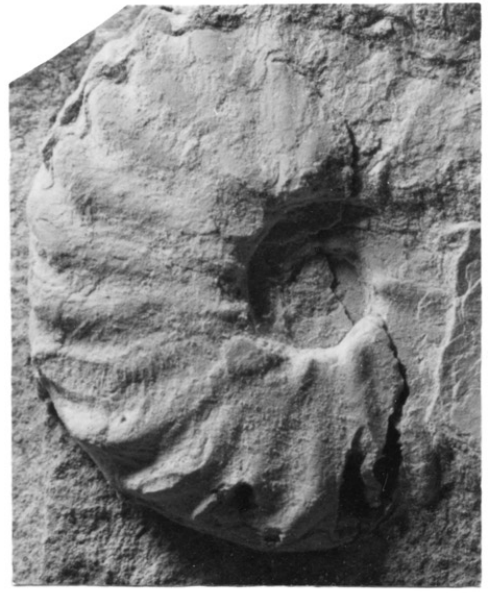

Q

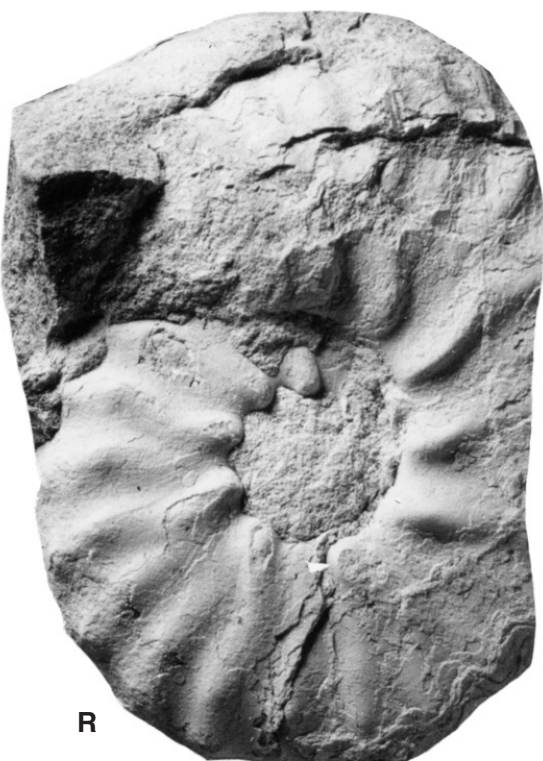

Fig. 9. A-D, Submantelliceras aumalense (Coquand, 1862). OUM K58121, from the Lower Cenomanian Mantelliceras mantellizone, Marnes de Ballon of St Mars-sous-Ballon, Sarthe, France. E-R, Submantelliceras prenodosoides (Boule, Lemoine \& Thévenin, 1907). E, H-J, M, OUM KX10315a; F, R, OUM KX10308; G, OUM KX10305; K, L, OUM KX10297; N, P, OUM KX10364; O, OUM KX10301, all from bed 3 at locality 181, Cenomanian I.Q, SAM-PCZ22413, from the Ndumu area. All specimens are from the Lower Cenomanian part of the Mzinene Formation. A, E, F, $\mathrm{K}, \mathrm{L}, \mathrm{N}, \mathrm{O}$, are $\times 1$; B-D, G-I, M, P-R, are $\times 2$. 


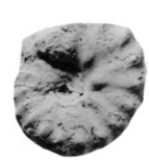

A

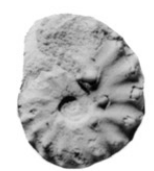

B

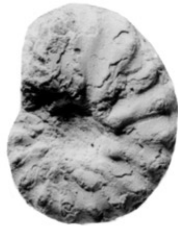

C

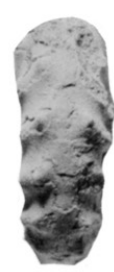

$\mathbf{J}$

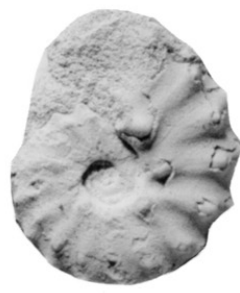

K

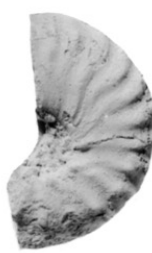

D

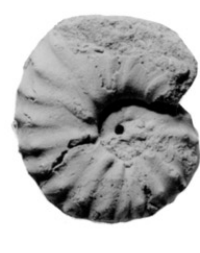

E

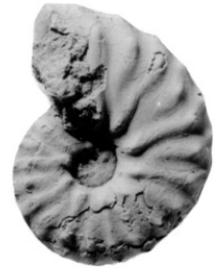

$\mathbf{F}$

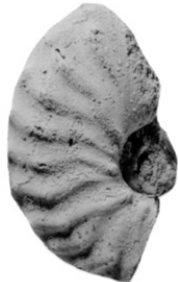

G

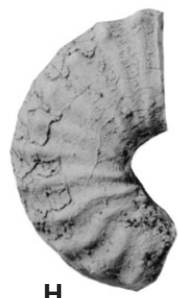

$\mathrm{H}$

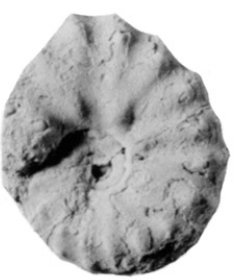

I

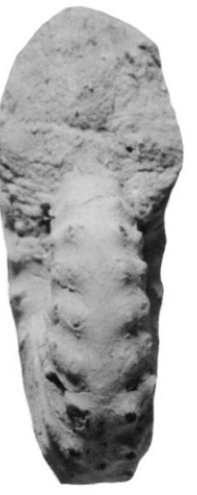

$\mathbf{P}$

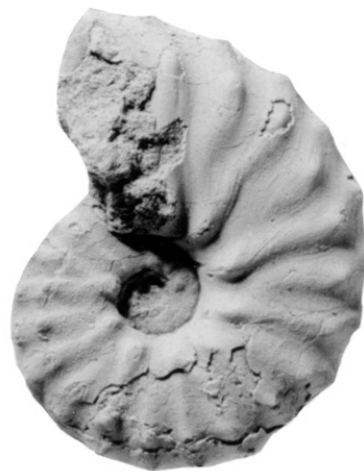

Q

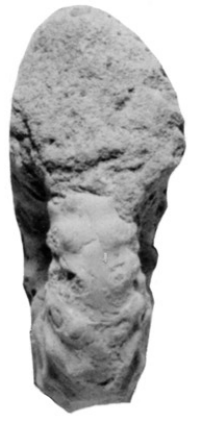

$\mathbf{L}$

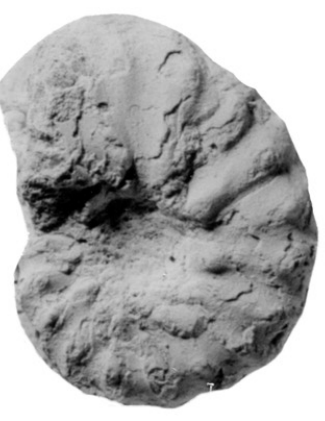

M

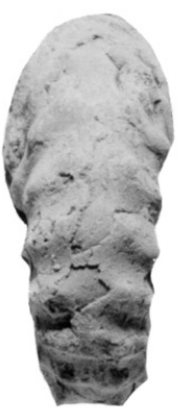

$\mathbf{N}$

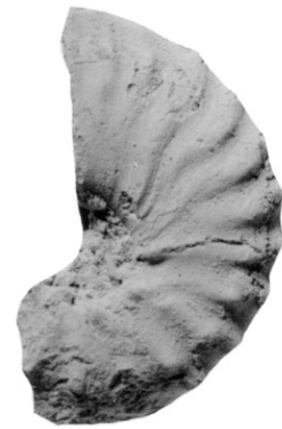

0

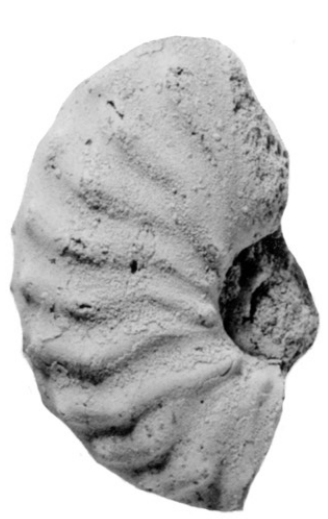

V

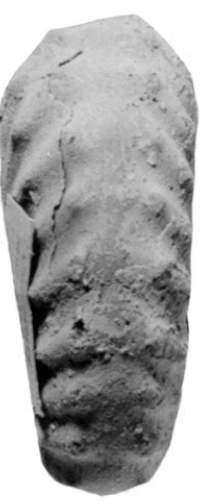

w

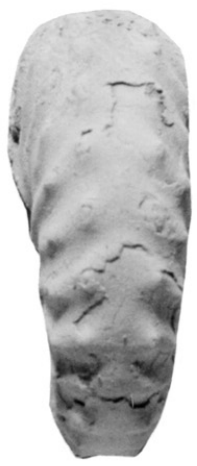

R

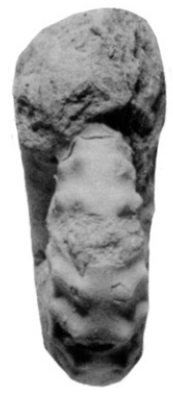

S

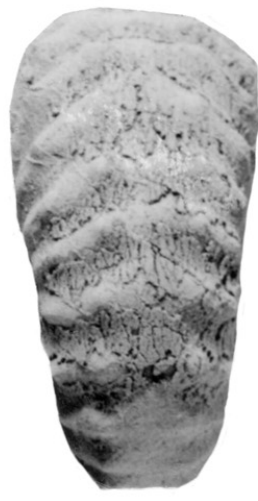

$Y$

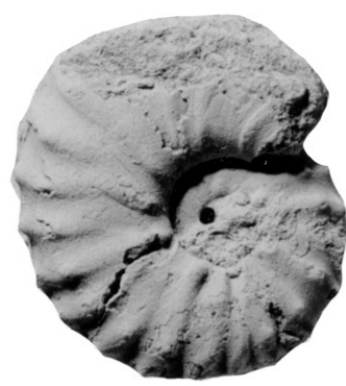

T

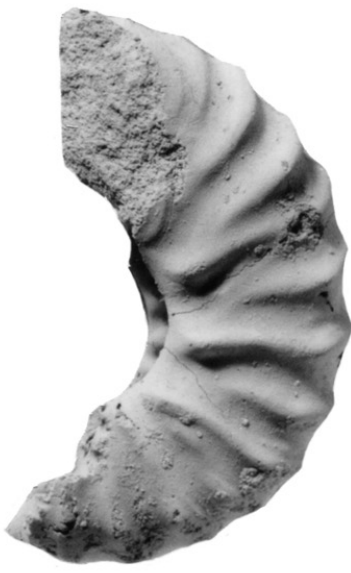

Z

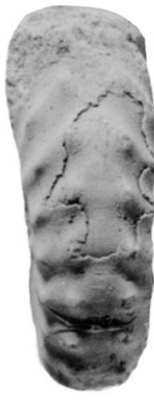

U

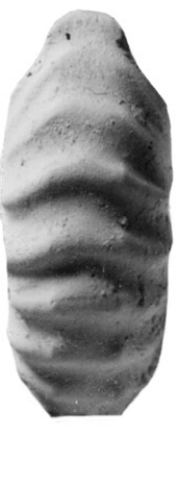

$Z^{\prime}$

Fig. 10. A-Z'. Submantelliceras prenodosoides (Boule, Lemoine \& Thévenin, 1907). A, I, J, SAM-PCZ21267; C, L-N, SAM-PCZ21247; D, O, SAM-PCZ21311; E, S-U, SAM-PCZ21310; F, P-R, SAM-PCZ21261, all from the Skoenberg. G, V, W, OUM KX11697; H, X, Y, OUM KX11698; Z, Z', OUM KX11964a, all from bed 6 at locality 61, the Skoenberg, Cenomanian I. All specimens are from the Lower Cenomanian part of the Mzinene Formation. Figures $\mathrm{A}-\mathrm{H}$ are $\times 1 ; \mathrm{I}-\mathrm{Z}$ are $\times 2$. 


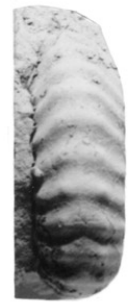

A

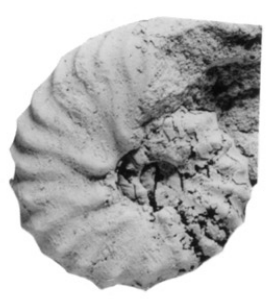

B

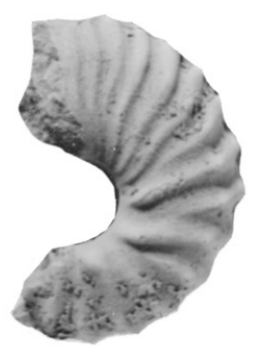

C

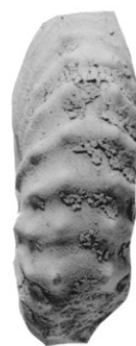

D

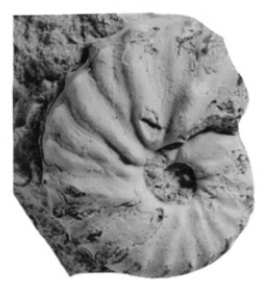

E

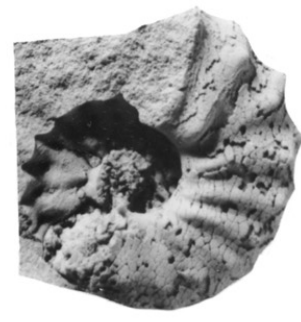

$\mathbf{F}$

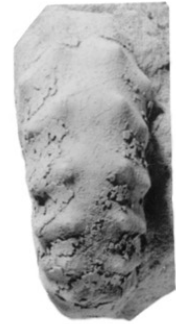

G

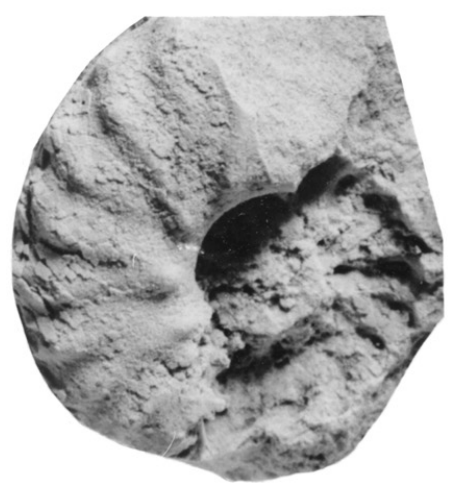

H

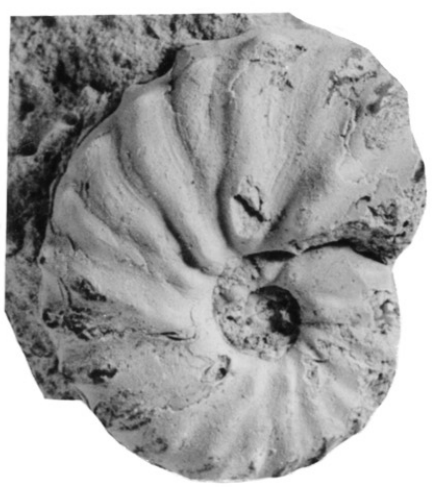

I

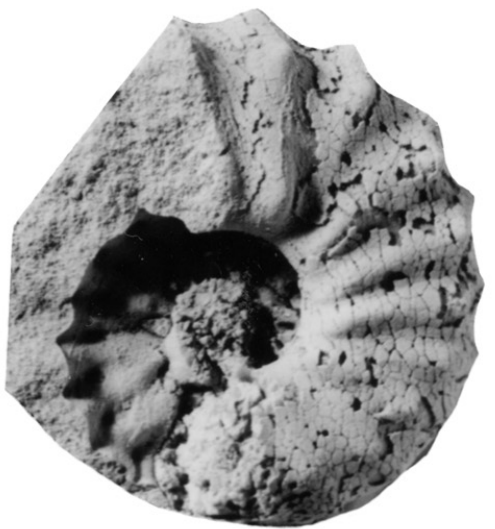

J

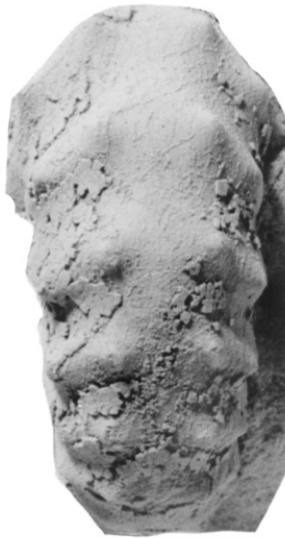

K

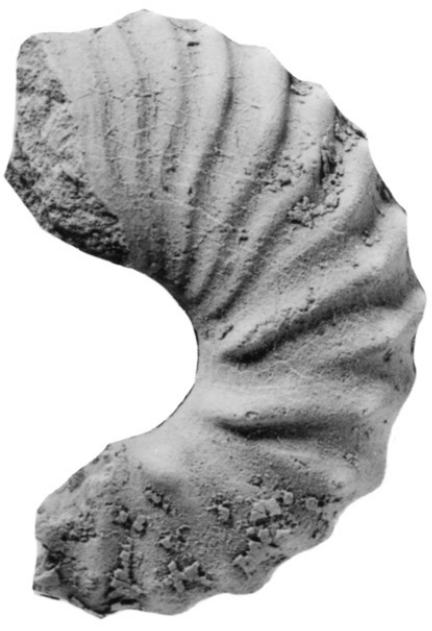

L

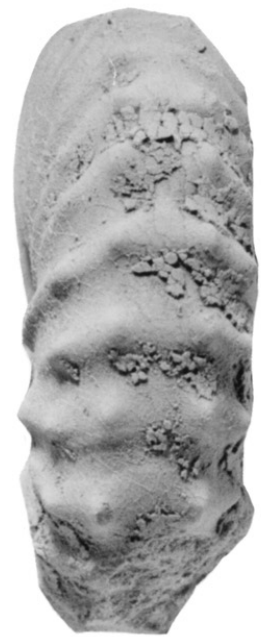

M

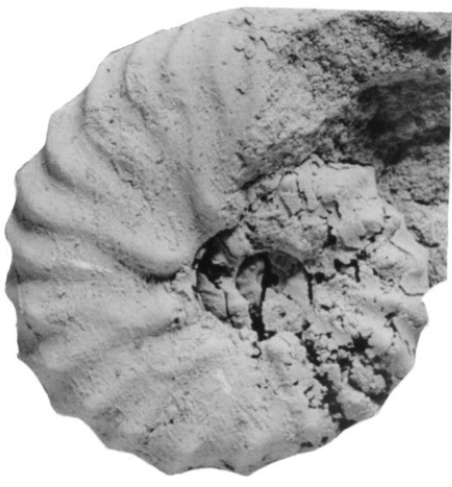

N

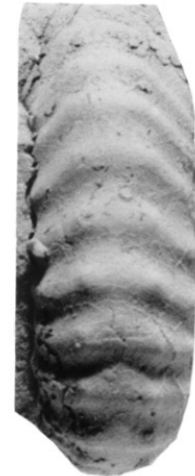

O

Fig. 11. A-O, Submantelliceras prenodosoides (Boule, Lemoine \& Thévenin, 1907). A, B, N, O, OUM KX11703; C, D, L, M, OUM KX11699; E, I, OUM KX11666; F, G, J, K, OUM KX11692, all from bed 6 at locality 61, the Skoenberg, Cenomanian I. All specimens are from the Lower Cenomanian part of the Mzinene Formation. Figures $A-G$ are $\times 1 ; \mathrm{H}-\mathrm{O}$ are $\times 2$. 


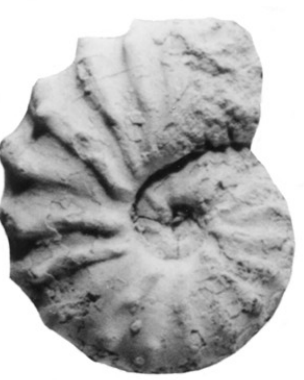

A

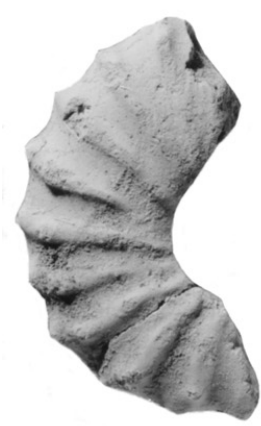

G

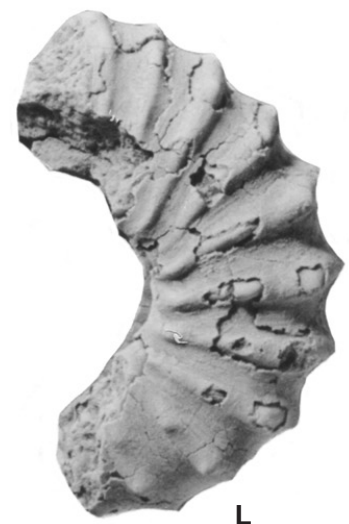

L

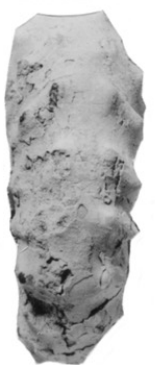

B

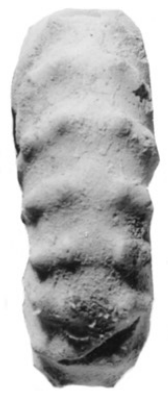

H

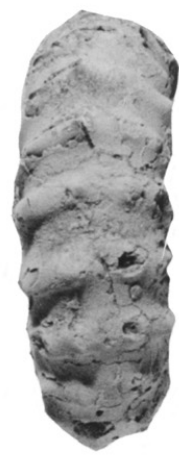

M

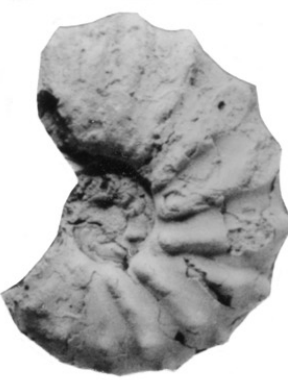

C

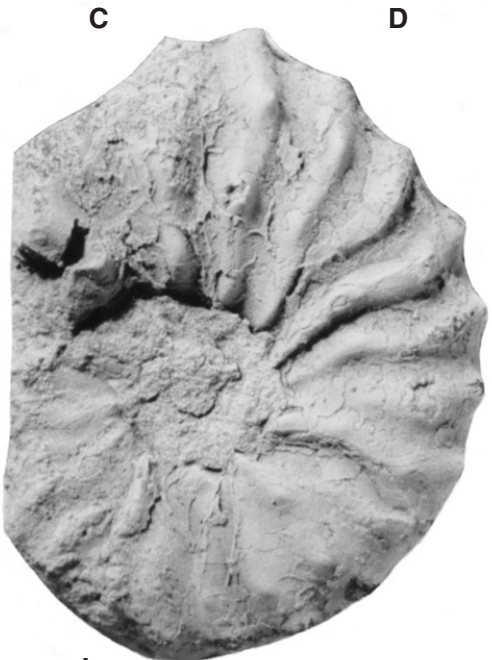

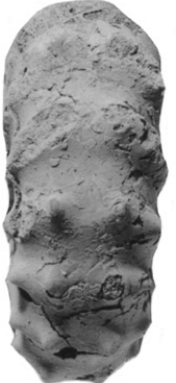

D

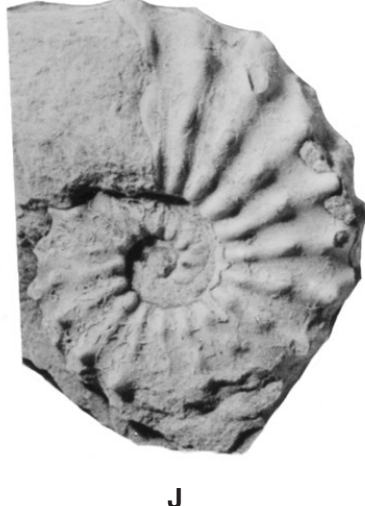

J

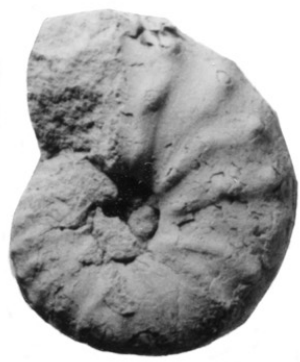

E

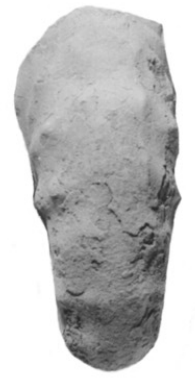

F
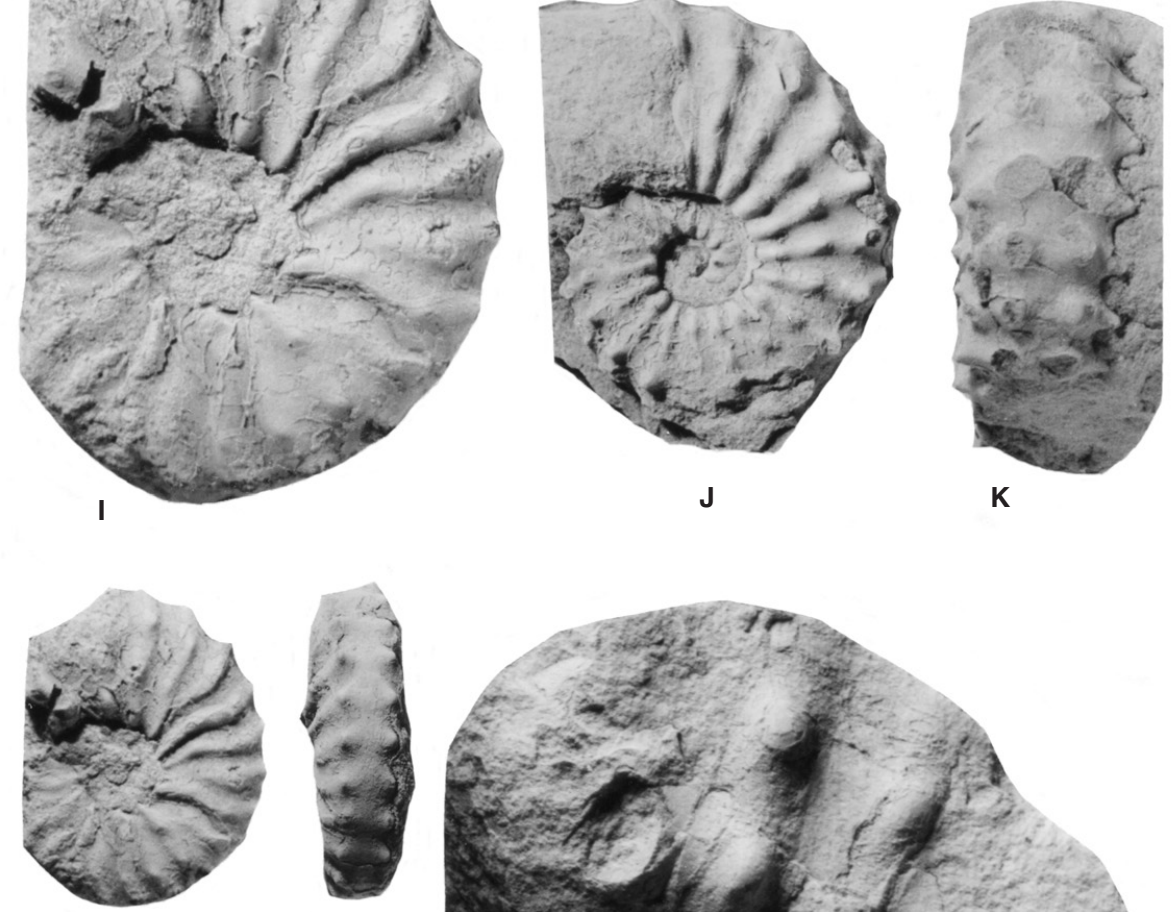

N
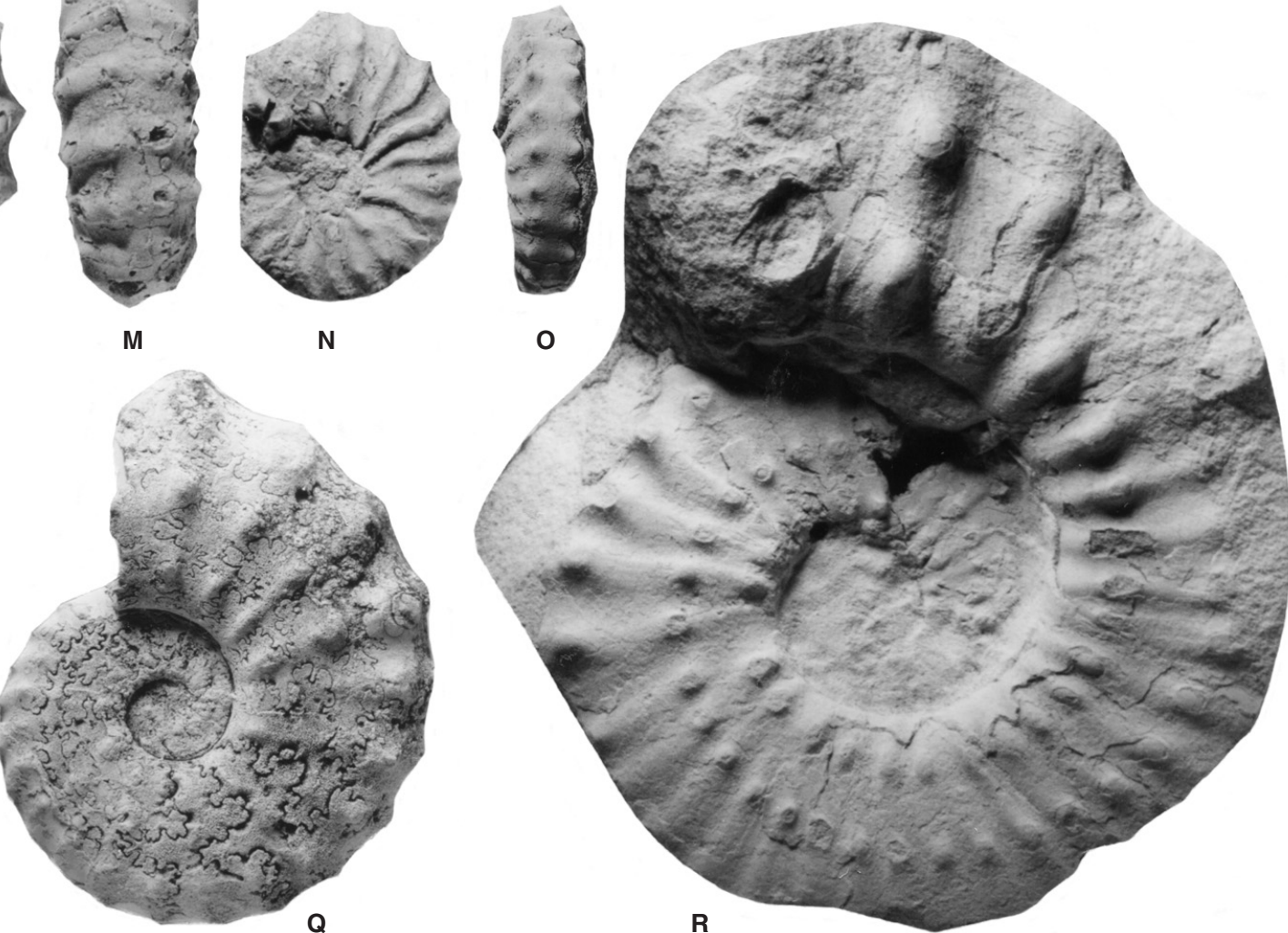

R

Fig. 12. A-I, L-O, Sharpeiceras minor sp. nov. A, B, paratype SAM-PCZ21297; E, F, paratype SAM-PCZ21283; L, M, paratype SAM-PCZ21298, all from locality 62, the Skoenberg. C, D, OUM KX1655, G, H, OUM KX11682, I, N, O, OUM KX11654, all from locality 61, bed 6, the Skoenberg, Cenomanian I. J, K,P, Q, Sharpeiceras florencae Spath, 1925. J, K, OUM KX10285a, P, Q, OUM KX10286, from locality 181, bed 3, in the Ndumu area, Cenomanian I. R, Sharpeiceras laticlavium (Sharpe, 1855). OUM KX10396, from locality 185, in the Ndumu area, Cenomanian I. All specimens are from the Lower Cenomanian part of the Mzinene Formation. Figures A-H, J-R are $\times 1 ; \mathrm{I}$ is $\times 2$. 


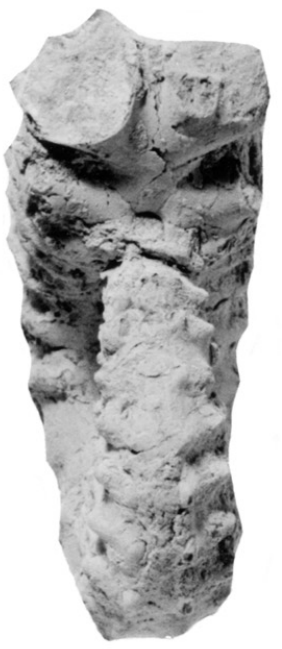

A

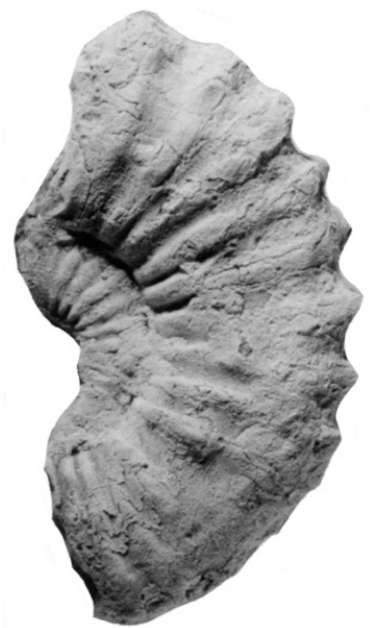

$\mathbf{F}$

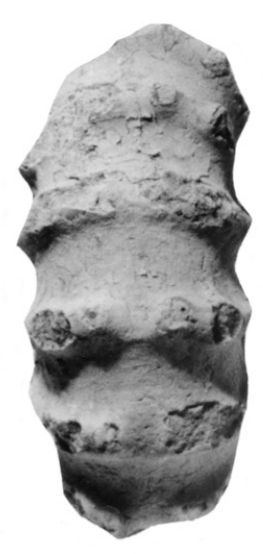

J

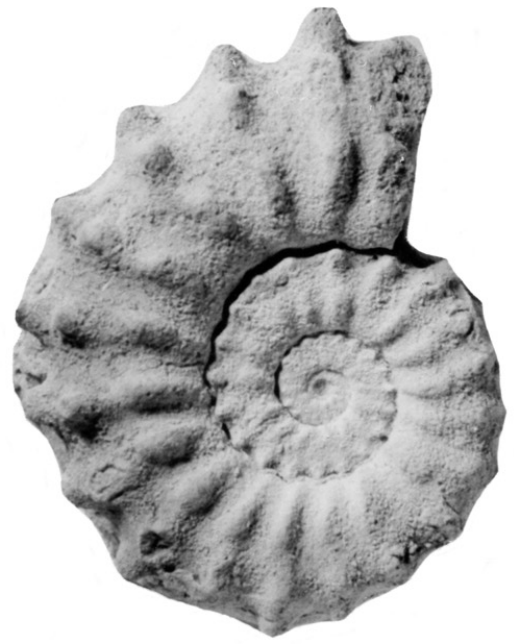

B

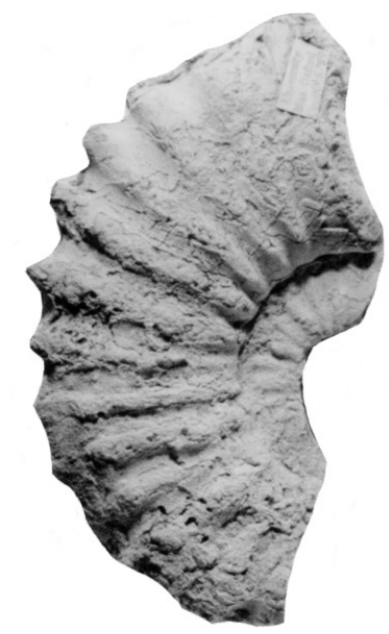

H

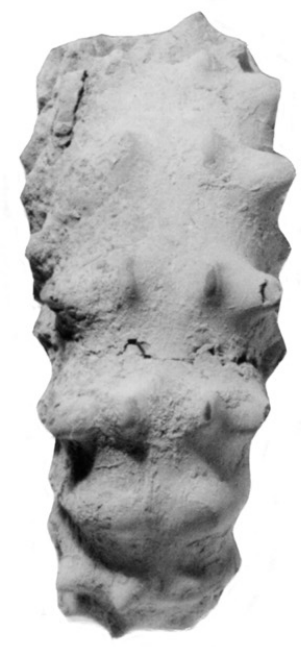

$\mathbf{L}$
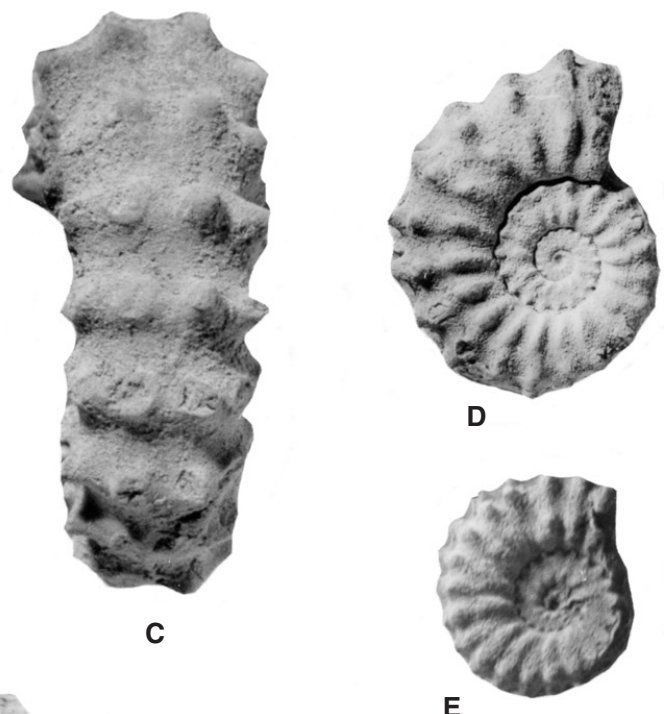

E

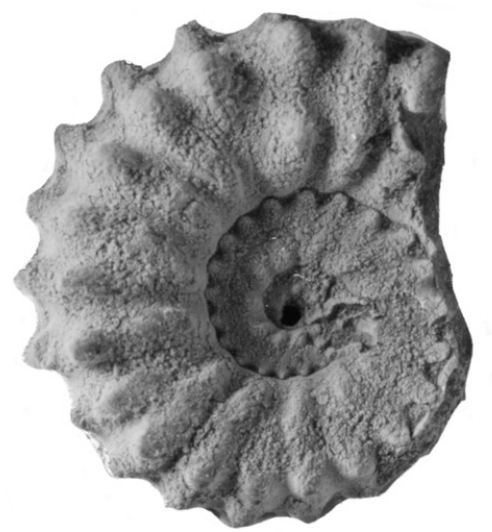

I

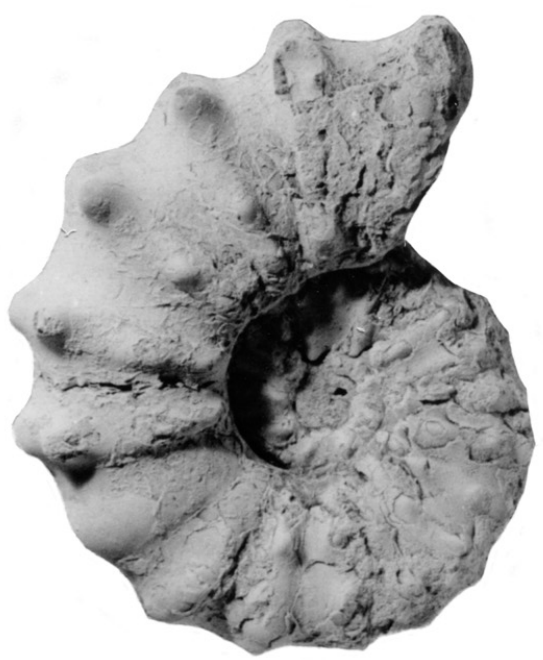

M

Fig. 13. A-E, I, Sharpeiceras falloti (Collignon, 1931). A-D, SAM-PCZ21304; E, I, SAM-PCZ21305, from the Skoenberg. F-H, Sharpeiceras mocambiquense (Choffat, 1903). OUM KX5789, from locality 62, the Skoenberg. J-M, Sharpeiceras minor sp. nov. J, K, paratype SAMPCZ21269; L, M, paratype SAM-PCZ21301, from the Skoenberg. All specimens are from the Lower Cenomanian part of the Mzinene Formation. Figures A-C, I, are $\times 2$; D-H, J-M, are $\times 1$. 

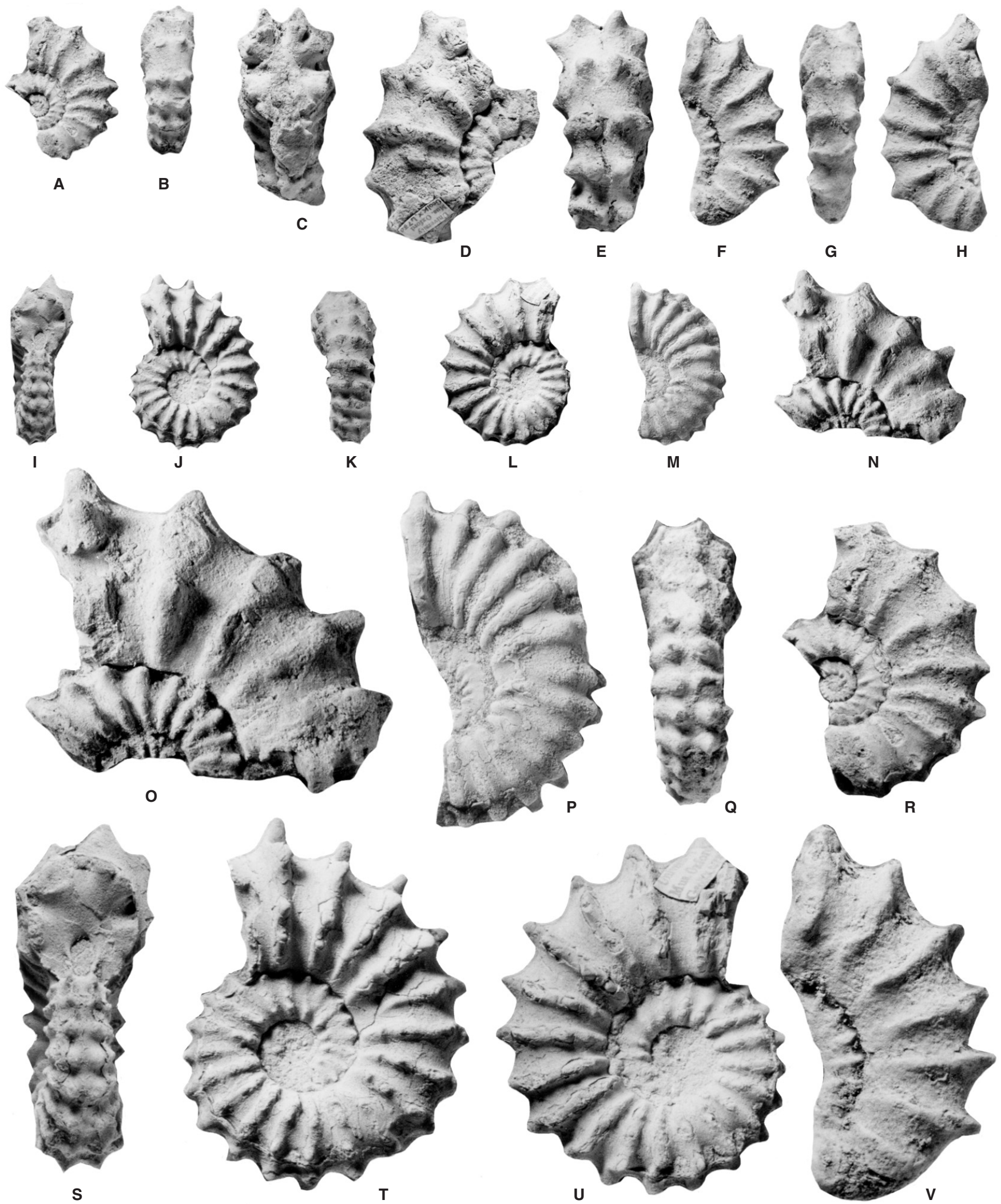

Fig. 14. A-V, Sharpeiceras falloti (Collignon, 1931). A, B, R, OUM KX4731; C-E, N, O, OUM KX4730; F-H, V, OUM KX4732; I-L, S-U, OUM KX4729; M, P, Q, OUM KX4725. All specimens are from the Lower Cenomanian part of the Mzinene Formation at locality 62, the Skoenberg. A-N are $\times 1 ; \mathrm{O}-\mathrm{V}$ are $\times 2$. 


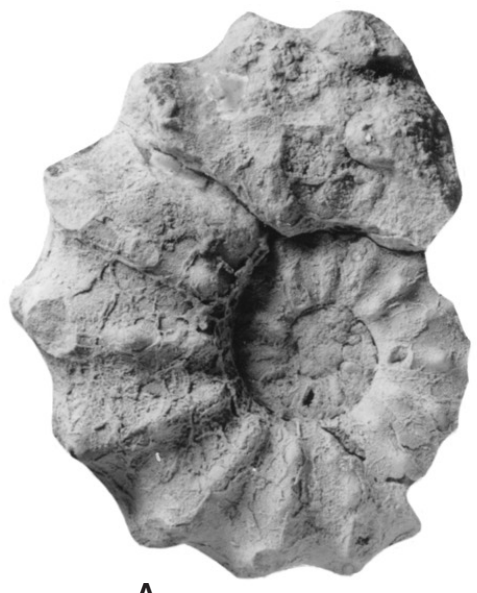

A

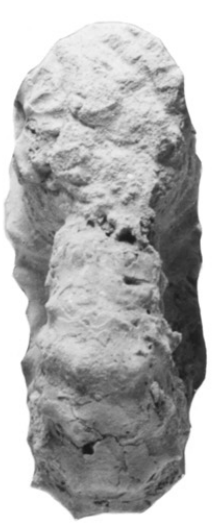

D

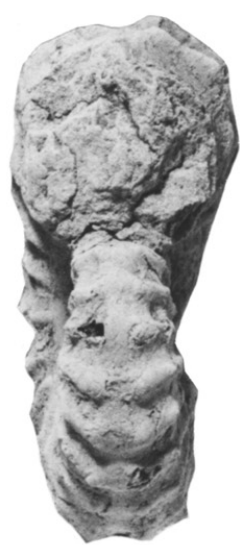

$\mathbf{F}$
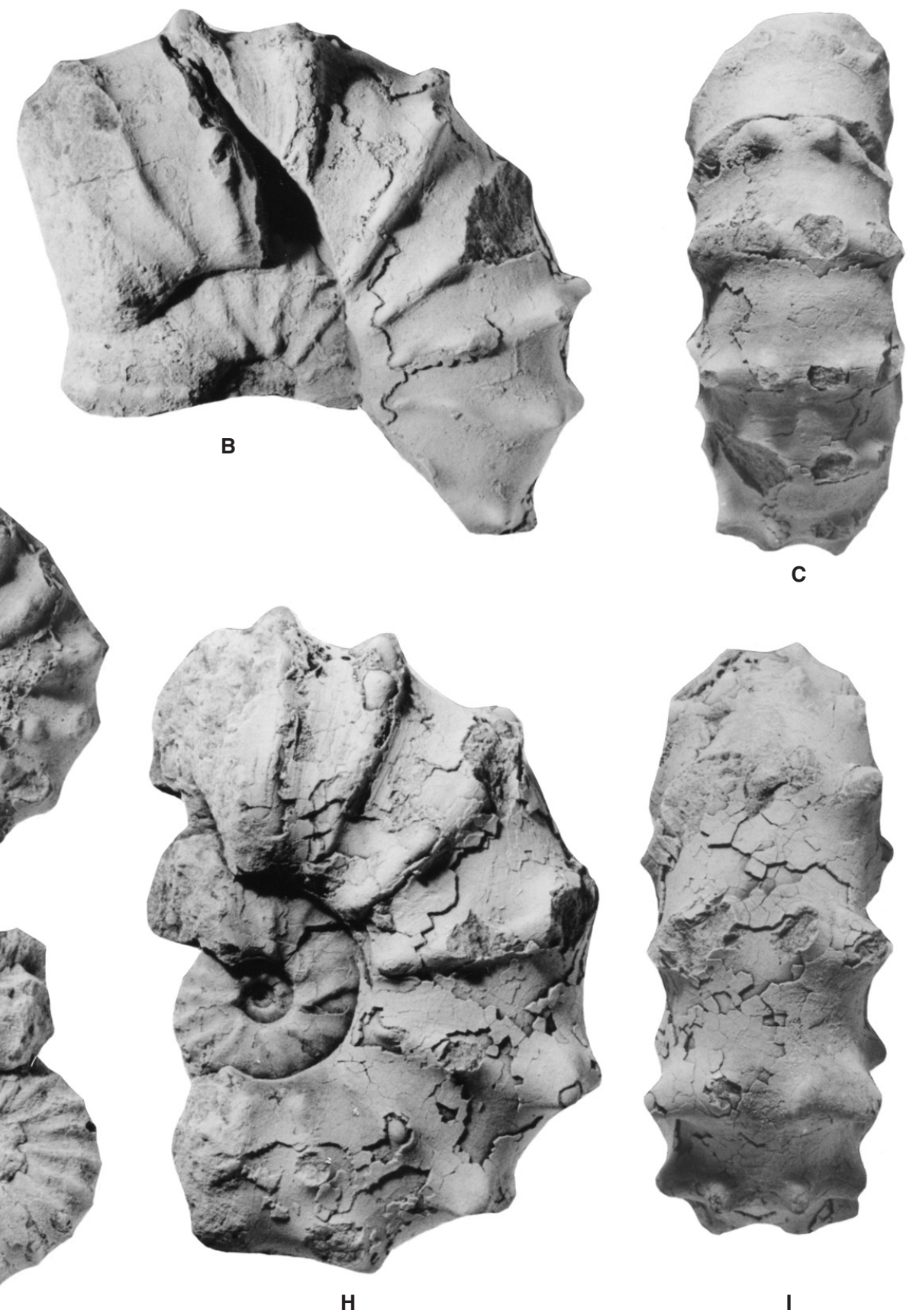

G

Fig. 15. A-I, Sharpeiceras minor sp. nov. A, OUM KX10277, from bed 3 at locality 181,Cenomanian I. B, C, paratype SAM-PCZ21292; D, E, paratype SAM-PCZ212302; H, I, the holotype, SAM-PCZ21296, F, G, all from the Skoenberg. All specimens are from the Lower Cenomanian part of the Mzinene Formation. All figures are $\times 1$. 


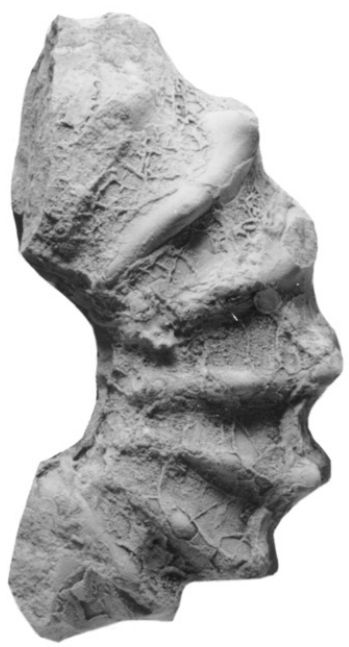

A

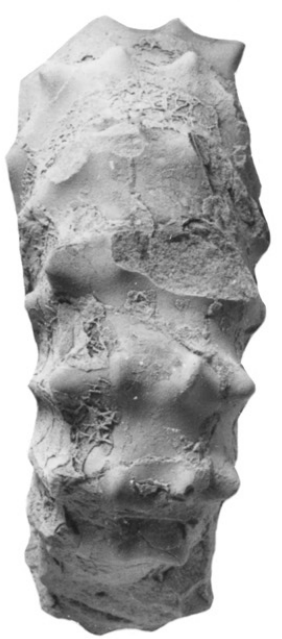

B

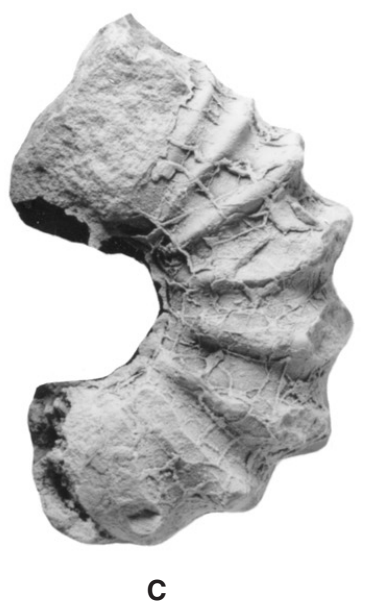

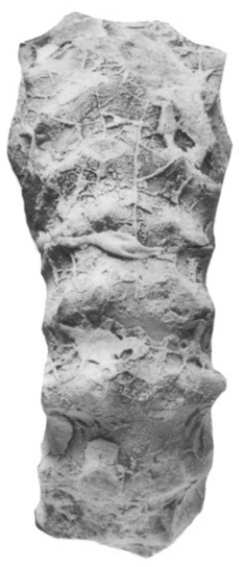

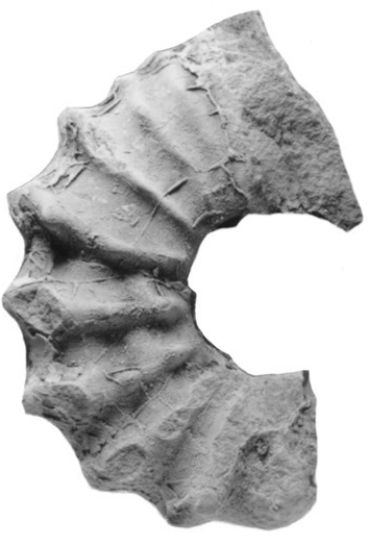

C

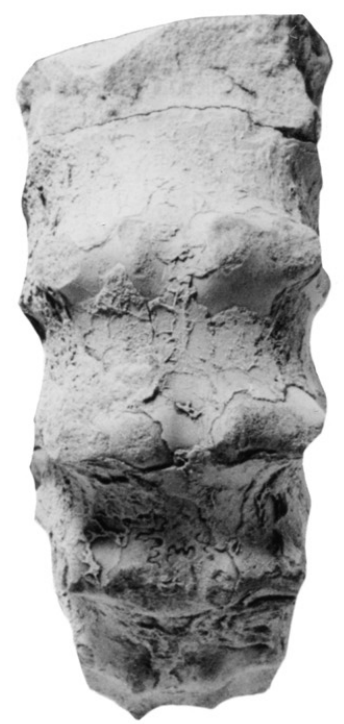

G

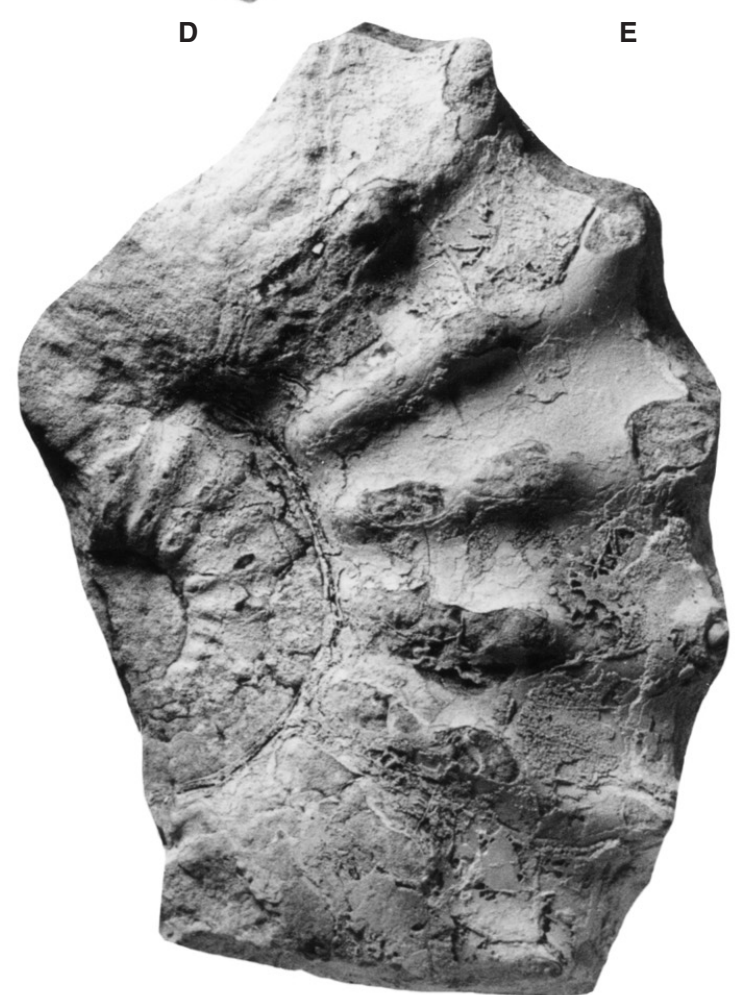

F

H

Fig. 16. A-E, Sharpeiceras minor sp. nov. A, B, paratype OUM KX10293; C-E, paratype OUM KX10290. F-H, Sharpeiceras florencae Spath, 1925. F, G, OUM KX10279; H, OUM KX10284. All specimens are from bed 3 at locality 181, in the Ndumu area, from the Mzinene Formation, Cenomanian I. All figures are $\times 1$. 

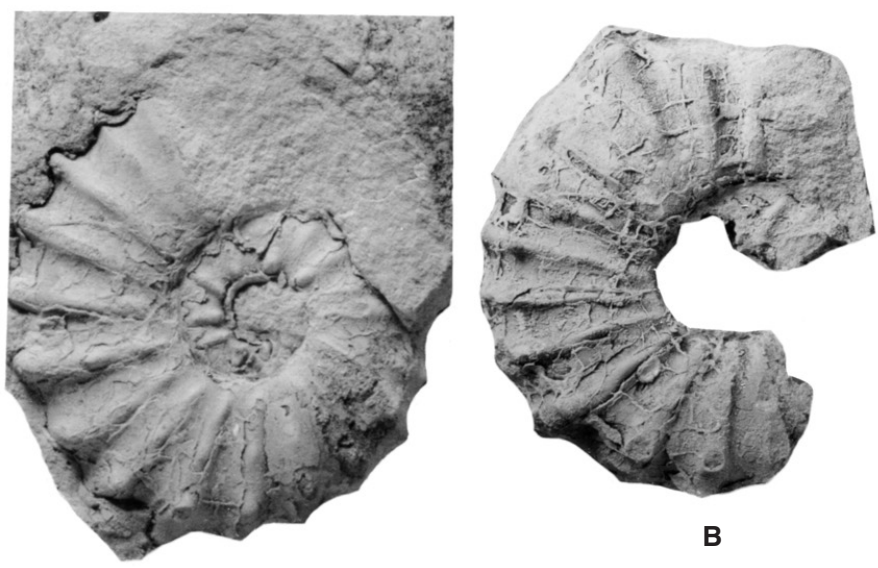

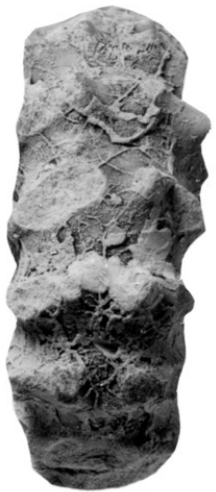

C

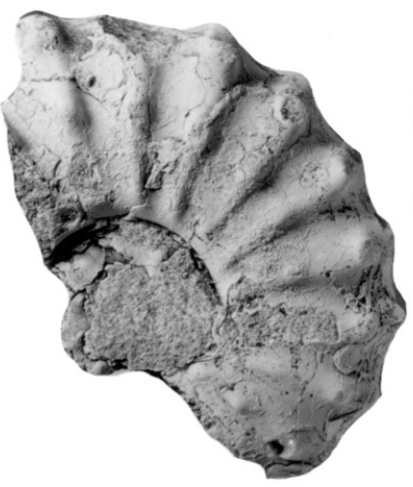

D

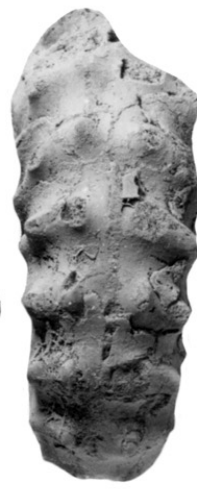

E

A

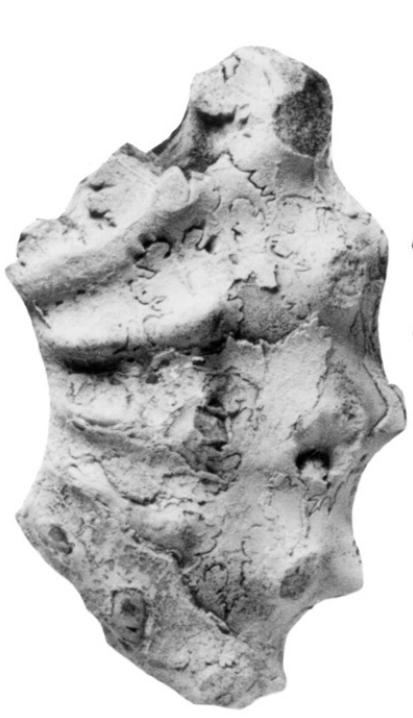

F

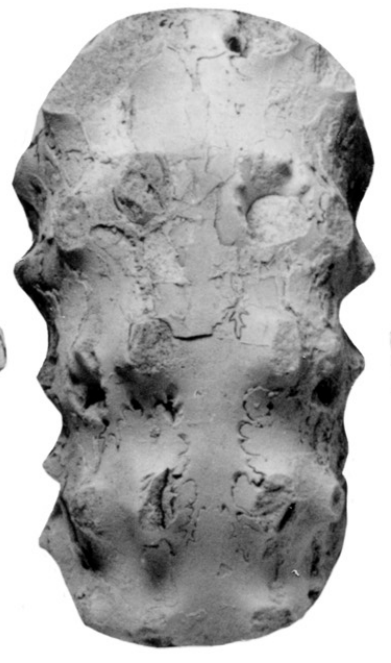

G

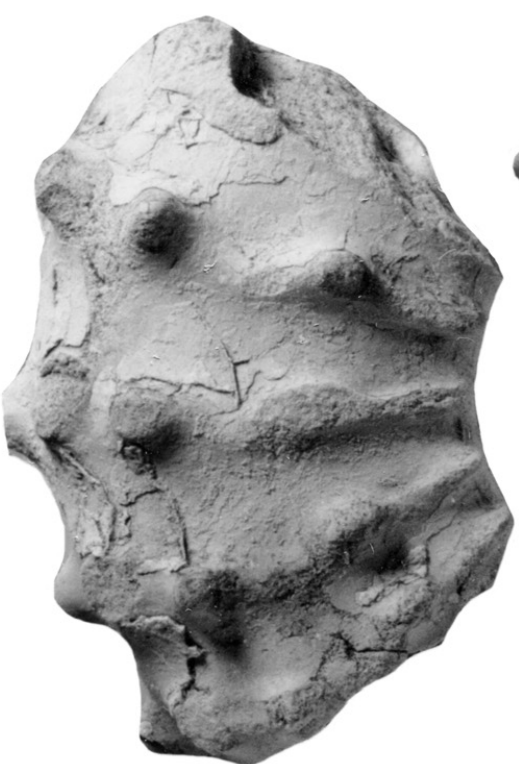

H

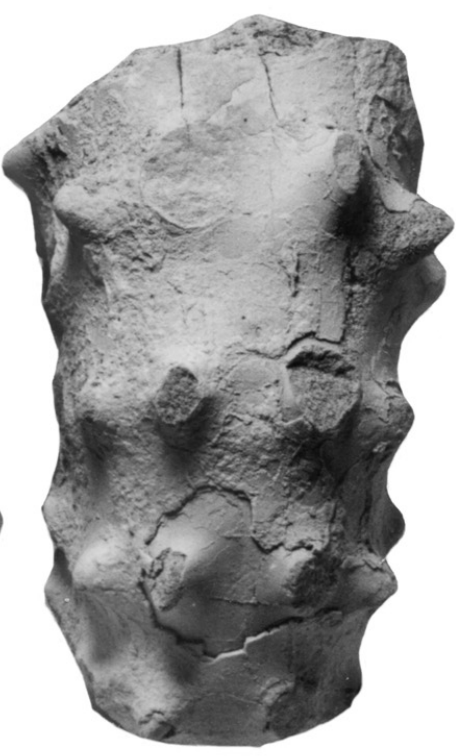

I

Fig. 17. A-E, Sharpeiceras minor sp. nov. A, paratype OUM KX10283b (see also Fig. 18); B, C, paratype OUM KX10321; D, E, paratype OUM KX10322. F-I, Sharpeiceras florencae Spath, 1925. F, G, OUM KX10288; H, I, OUM KX10289. All specimens are from bed 3 of the Mzinene Formation at locality 181 , in the Ndumu area, Cenomanian 1 . All figures are $\times 1$. 

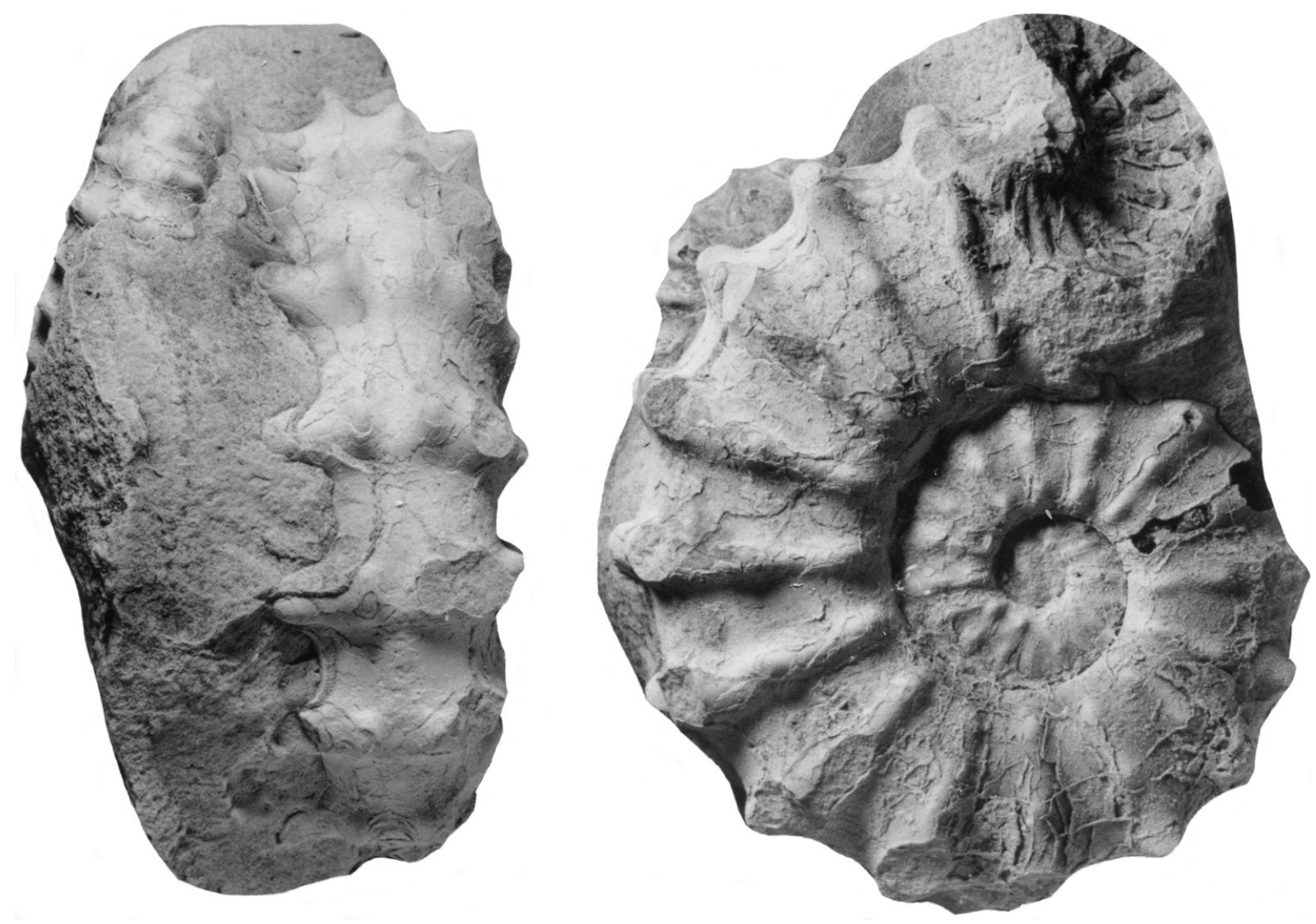

Fig. 18. Sharpeiceras minorsp. nov. Paratype OUM KX10283a, with the venter of paratype OUM KX10283b visible at the top left of the left hand figure. From bed 3 of the Mzinene Formation at locality 181, in the Ndumu area, Cenomanian 1. Figures are $\times 1$. 

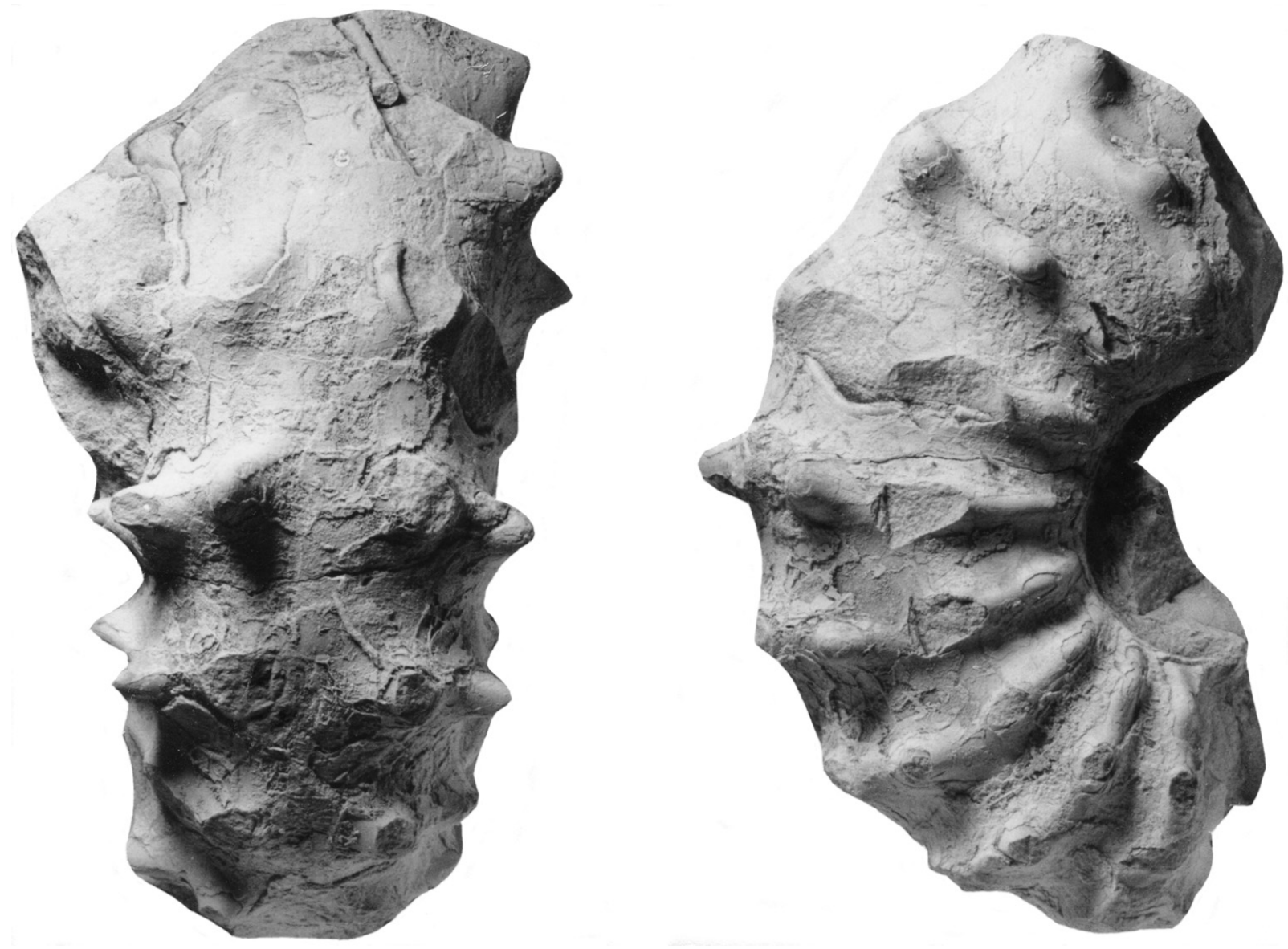

Fig. 19. Sharpeiceras florencae Spath, 1925. OUM KX10282, from bed 3 of the Mzinene Formation at locality 181, in the Ndumu area, Cenomanian 1. Figures are $\times 1$. 


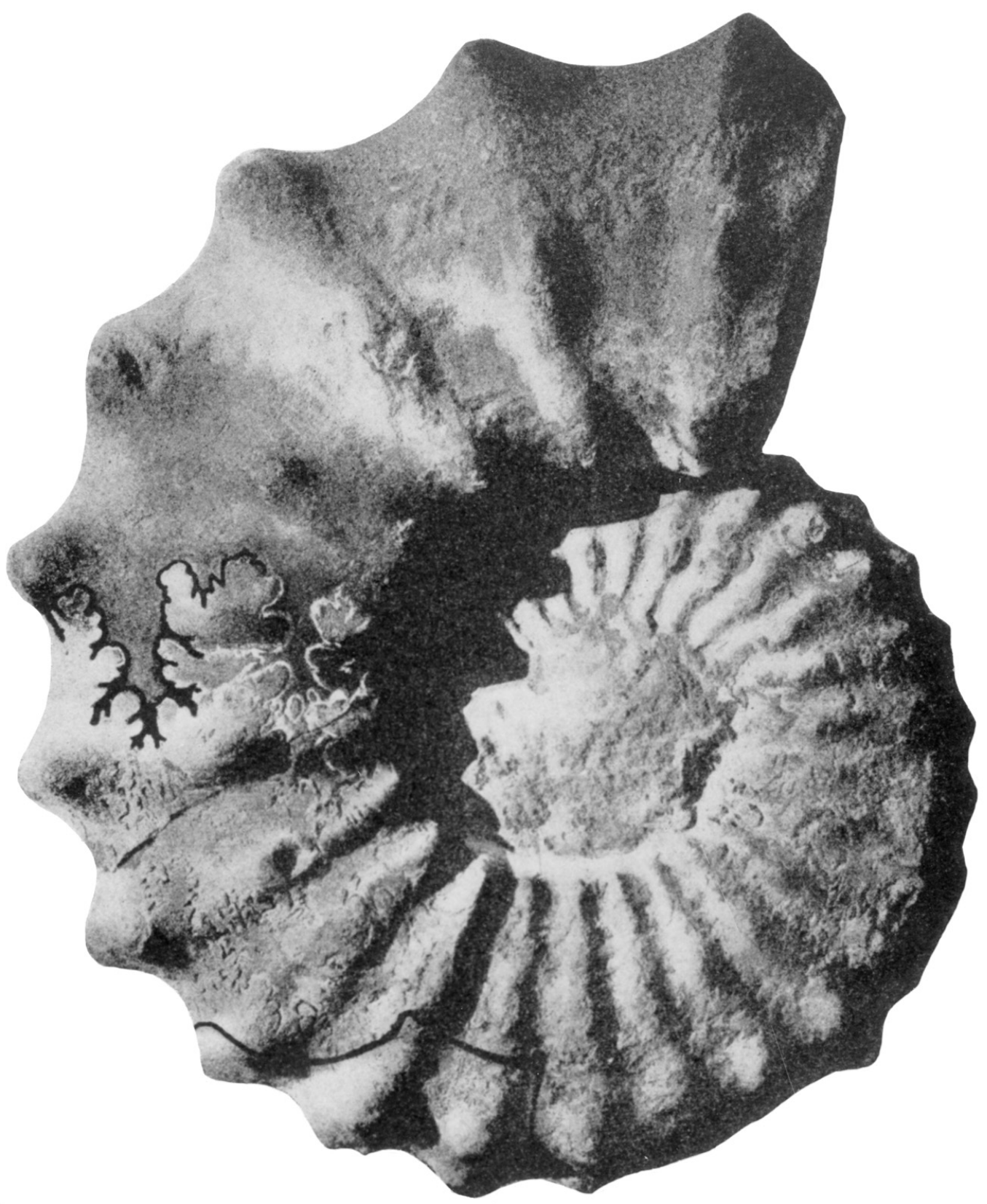

Fig. 20. Sharpeiceras florencae Spath, 1925. The holotype; copy of Spath 1925, pl. 37. The original is no. 1492 in the collections of the Ditsong National Museum of Natural History, and is from the Cenomanian of northern KwaZulu-Natal ('Maputoland'). Reduced $\times 0.78$; the original is approximately $220 \mathrm{~mm}$ in diameter. 


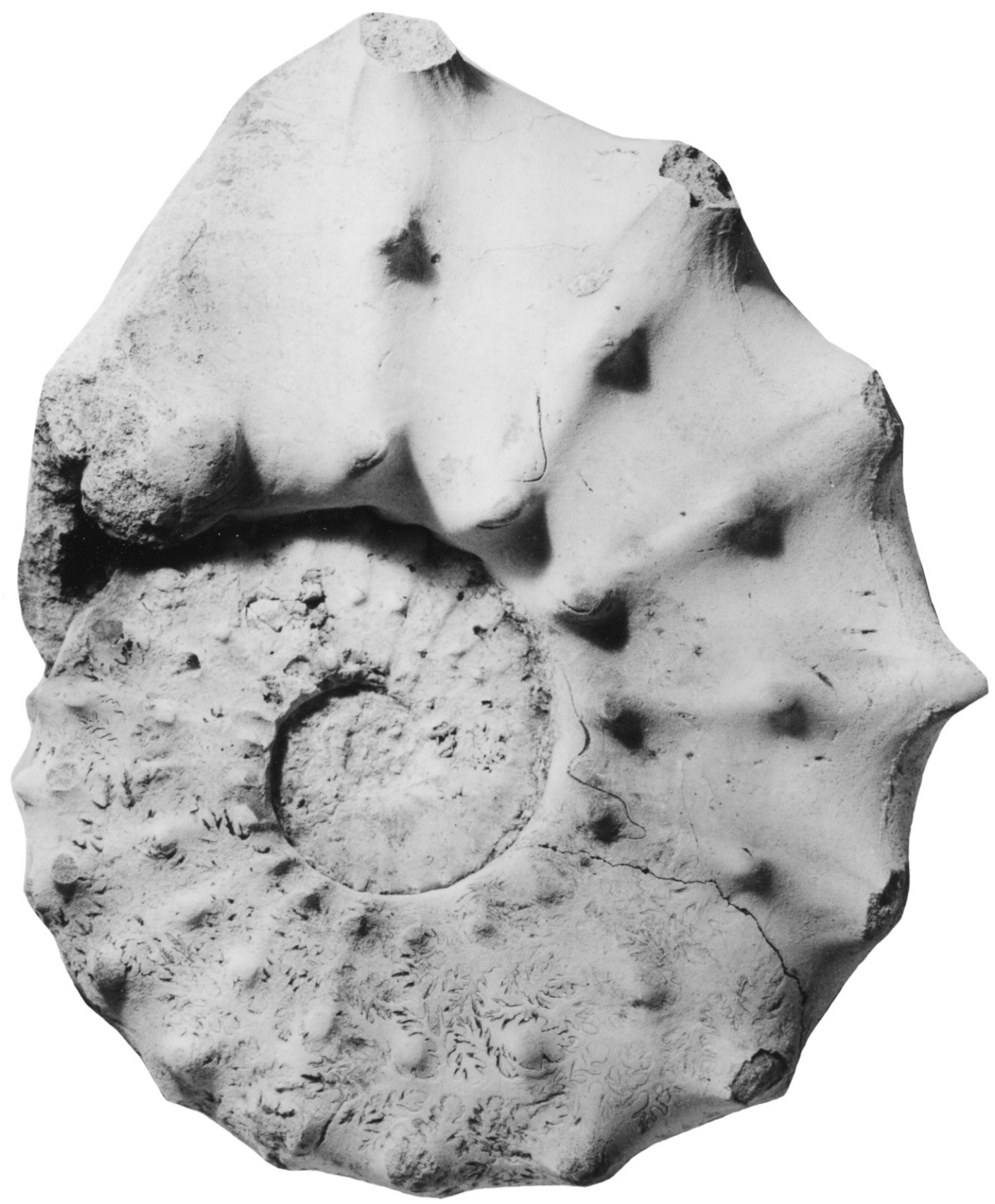

Fig. 21. Sharpeiceras florencae Spath, 1925. The holotype of Sharpeiceras vohipalense Collignon, 1964, the original of Collignon, 1964, p. 104, pl. 354, fig. 1565, from the Lower Cenomanian of Collignon's gisement 486, Collines Vohipaly, niveau supérieur, Madagascar. The original is housed in the collections of the Université de Bourgogne, Dijon. See also Figure 22E. Figure is $\times 1$. 

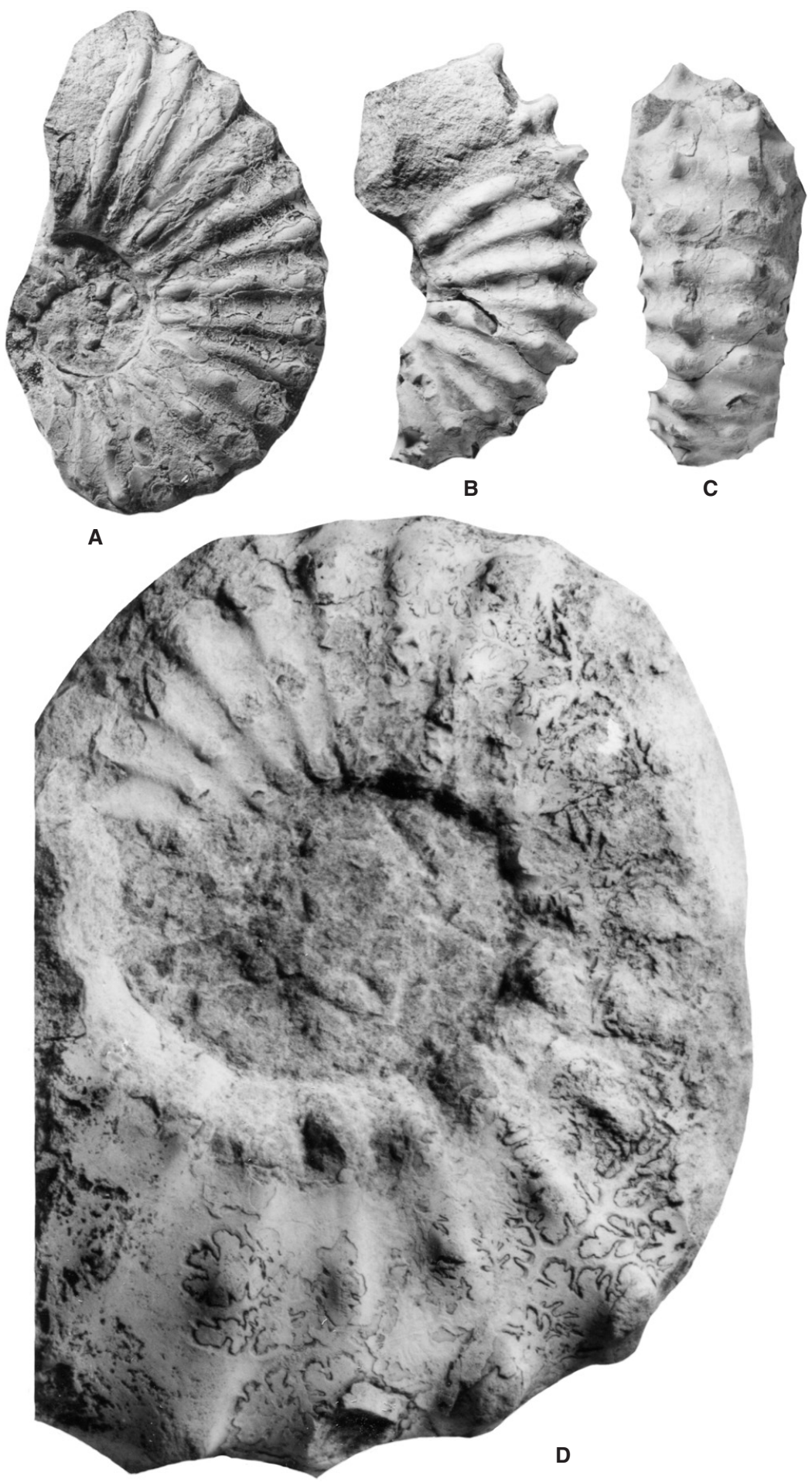

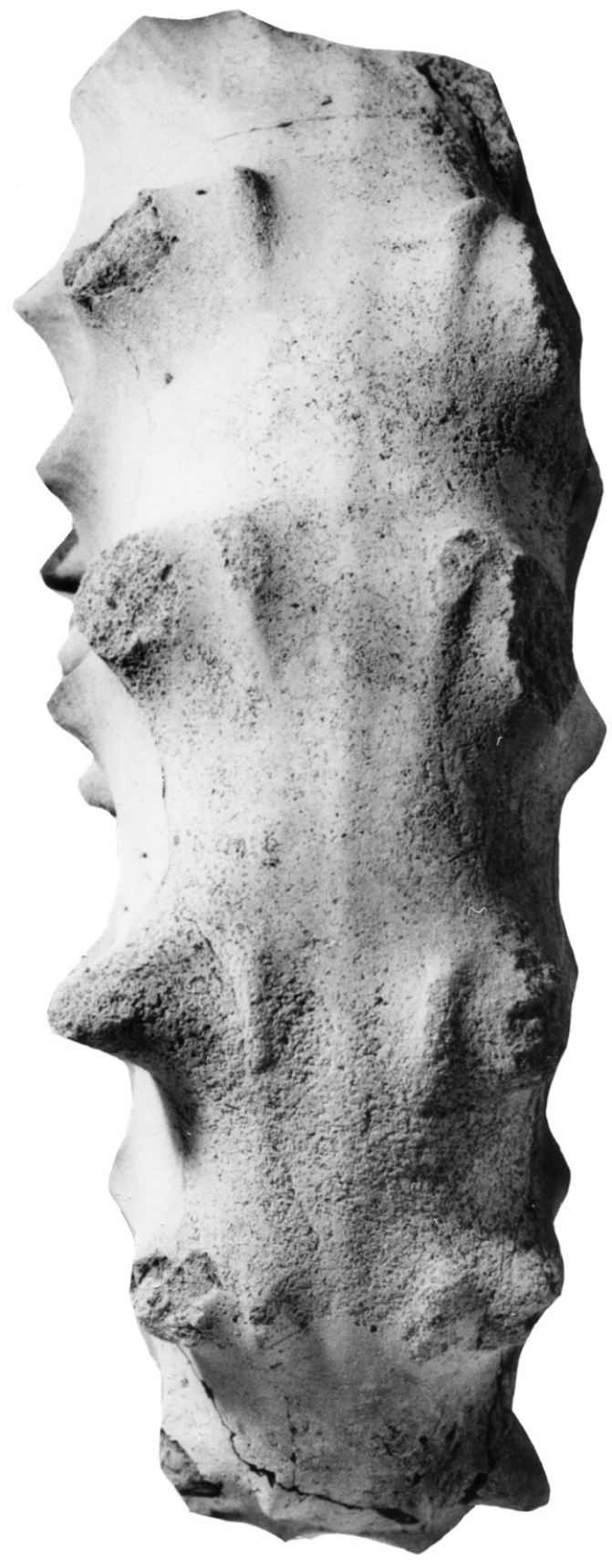

$\mathrm{E}$

Fig. 22. A, Mantelliceras lateretuberculatum Collignon, 1964. OUM KX10389. B, C, Mantelliceras picteti Hyatt, 1903, OUM KX103881b. Both specimens are from locality 183, in the Ndumu area, Cenomanian II. D, E, Sharpeiceras florencae Spath, 1925. D is the original of Sharpeiceras schlueteri Hyatt, 1903 of Collignon 1964, p. 102, pl. 353, fig. 1564, from the Lower Cenomanian of his gisement 362, Antanimananga 1 (Mandabe), Madgascar. E, The holotype of Sharpeiceras vohipalense Collignon, 1964, the original of Collignon, 1964, p. 104, pl. 354, fig. 1565, from the Lower Cenomanian of Collignon's gisement 486, Collines Vohipaly, niveau supérieur, Madagascar. The originals of D and E are housed in the collections of the Université de Bourgogne, Dijon. All figures are $\times 1$. 


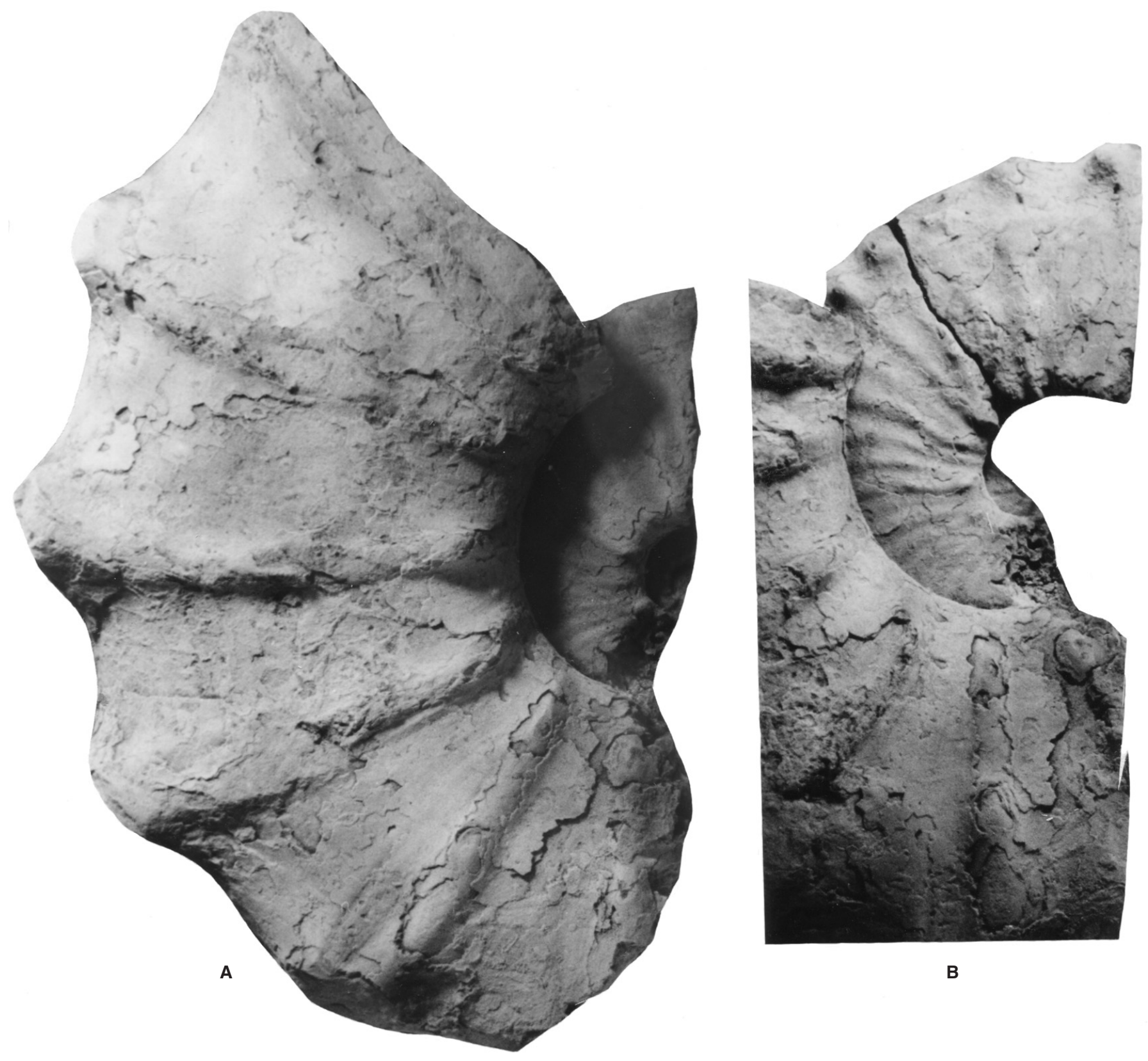

Fig. 23. A, B, Sharpeiceras sp. B, SAM-PCZ19847, from the Lower Cenomanian part of the Mzinene Formation of the Skoenberg. Figure A is $\times 0.56$; $B$ is $\times 0.65$. 